UCRL-ID-148014

\title{
Isotopic Tracers for Delineating Non-Point Source Pollutants in Surface Water
}

\author{
M.L. Davisson
}

March 1, 2001

U.S. Department of Energy

Lawrence

Livermore

National

Laboratory 


\section{DISCLAIMER}

This document was prepared as an account of work sponsored by an agency of the United States Government. Neither the United States Government nor the University of California nor any of their employees, makes any warranty, express or implied, or assumes any legal liability or responsibility for the accuracy, completeness, or usefulness of any information, apparatus, product, or process disclosed, or represents that its use would not infringe privately owned rights. Reference herein to any specific commercial product, process, or service by trade name, trademark, manufacturer, or otherwise, does not necessarily constitute or imply its endorsement, recommendation, or favoring by the United States Government or the University of California. The views and opinions of authors expressed herein do not necessarily state or reflect those of the United States Government or the University of California, and shall not be used for advertising or product endorsement purposes.

This work was performed under the auspices of the U. S. Department of Energy by the University of California, Lawrence Livermore National Laboratory under Contract No. W-7405-Eng-48.

This report has been reproduced directly from the best available copy.

Available electronically at http://www.doe.gov/bridge

Available for a processing fee to U.S. Department of Energy

and its contractors in paper from

U.S. Department of Energy

Office of Scientific and Technical Information

P.O. Box 62

Oak Ridge, TN 37831-0062

Telephone: (865) 576-8401

Facsimile: (865) 576-5728

E-mail: reports@adonis.osti.gov

Available for the sale to the public from

U.S. Department of Commerce

National Technical Information Service

5285 Port Royal Road

Springfield, VA 22161

Telephone: (800) 553-6847

Facsimile: (703) 605-6900

E-mail: orders@ntis.fedworld.gov

Online ordering: http://www.ntis.gov/ordering.htm

OR

Lawrence Livermore National Laboratory

Technical Information Department's Digital Library

http://www.llnl.gov/tid/Library.html 
Isotopic Tracers for Delineating Non-point Source Pollutants in Surface Water

M. Lee Davisson

Environmental Chemistry and Toxicology Group

Health and Ecological Assessment Division

Lawrence Livermore National Laboratory

March, 2001 


\section{Executive Summary}

\section{Background}

Roughly half the domestic drinking water supplies in the United States originate from direct treatment of surface water. A surface water system is defined by its watershed, which is an area constrained by topographic boundaries, and all stream flow converges at a single point within those boundaries. The water quality of discharge from the surface water system is ultimately dictated by landuse and climate within the watershed. Before approximately 1980 , point source discharge from industry and urban waste threatened drinking water quality and its treatability in many lakes and rivers. Water quality has vastly improved from point source reduction measures, yet, non-point source pollutants continue to rise. One of the major non-point source pollutants of concern is water-borne pathogens, and of equal concern are the risks associated with pathogen disinfection and formation of potentially hazardous byproducts. This has lead to the promulgation of the Information Collection Rule, and ultimately the implementation of the DisinfectantsDisinfection By-Product Rule. The extent of pathogen occurrence combined with the total organic carbon (TOC) concentration and its reactivity during disinfection will determine the extent of regulation and treatment schemes.

\section{$\underline{\text { Data Needs }}$}

Any regulation of TOC at the treatment plant will increase costs. As a result, management of pathogen and TOC generating processes in the watershed upstream of the treatment point has gain increased interest, and has fallen under the general category of watershed management. The scientific component of watershed management depends on 
acquiring knowledge that links water quality sources with geographic regions. However, there is an observational gap in this knowledge. In particular, almost all the water quality data that exists at a utility are of high frequency collected at a single point over a long period of time. Water quality data for utility purposes are rarely collected over an entire watershed. The potential is high, however, for various utilities in a single watershed to share and integrate water quality data, but no regulatory incentives exist at this point. The only other available water quality data originate from special scientific studies.

Unfortunately these data rarely have long-term records and are usually tailored to address unrelated research questions. The goal of this research was to investigate whether scientific research tools were available that could provide evidence that links water quality and land type. In particular, could such tools be used on raw water at the treatment point rather than monitoring over a large geographic spanning a watershed. This report summarizes the utility of using isotopic tracers to better understand sources of non-point source pollution and their relation to industry standard water quality measurements.

\section{$\underline{\text { Summary of Research Results }}$}

In this study we have found that much of the water quality data generated by utilities is under-interpreted in the context of understanding watershed processes. For example, the City of St. Louis depends solely on the Missouri River for drinking water, but due to large variability in discharge and runoff sources, they are faced with TOC concentrations that vary nearly a factor of three within a single season. Until this study, the relationship between discharge and concentration has not been constrained. However, we found a 
linear correlation between the TOC concentration and the fractional amount of downstream discharge (derived from within the State of Missouri). This correlation relates directly to differences in land use and climate between the upstream and downstream portions of the river basin.

In addition to using utility water quality data to better understand non-point source pollutants, non-regulatory type data can be generated to enhance observational knowledge. Data such as isotopic measurements of water and dissolved constituents can provide indirect evidence for sources and the processes governing the occurrence and concentration of non-point source pollutants. For example, using isotope measurements of carbon-13 on TOC in the Missouri River, we were able to distinguish carbon originating from algae photosynthesis versus that generated from land plant material. Their relative proportions correlated with season and water temperature. We also found that the carbon-14 abundance of TOC decreased with increasing humic substances, indicating that at various times TOC comprises older sources of carbon. Humic material also preferentially forms tri-halomethanes during chlorination, relative to the remaining portion of TOC. The carbon-14 abundance of humic substances showed a strong inverse correlation to electrical conductivity. This relationship provided a basis to delineate the geographic source of the TOC. In addition, the carbon-14 of humic isolates from several rivers located in the westèn hemisphere, representing different climates, positively correlated with mean annual precipitation, indicating a strong relationship between solublization rates of soil carbon and regional climate. This may provide a predictive basis for humic sources in watersheds similar to the Missouri River. 
The oxygen-18 abundance of surface water from large rivers in Missouri and California can delineate geographic sources of runoff from various parts of the watershed. The oxygen-18 correlation to water quality parameters was shown to verify geographic sources of TOC and dissolved salts in the Missouri River. However, during storm flows or anomalous events such as El Nino, the oxygen-18 shows strong perturbations from long-term averages. Nevertheless, in large California rivers significant changes in oxygen-18 abundance during storm runoff can delineate local runoff sources versus regional ones. This measurement may be useful for predicting storm water quality related to different geographic land uses.

\section{Introduction}

\section{Background to Current Surface Water Quality Problems}

The rising problem of industrial and urban waste water discharge to rivers in the US during the mid-1900s sparked the need to regulate point-source pollution discharge. This gave rise to enactment of the Clean Water Act in 1972, which over the past $\sim 30$ years resulted in $98 \%$ reduction in metals and organics according to the USEPA. Today 60 to $70 \%$ of surface water currently meets quality standards. Much of this has been accomplished by implementing a permitting process for point source discharge, which required public financing of waste water treatment facilities and use of best available technology. However, 30 to $40 \%$ of rivers still do not meet water quality standards for reasons that include impact from urban storm water runoff, agricultural and livestock runoff, and loss of wetlands. These causes differ from those responsible for poor water 
quality prior to 1972 , in that they are generated for the most part by non-point sources and land use changes.

Non-point source pollution results from specific land types or land use activities, which can create pollutant loads of a moderate to low level, but which occur over large geographic areas and have a cumulative effect. For example, agricultural areas of the midwestern states within the Mississippi River drainage are thought to contribute the bulk of the annual nitrogen loads transported out to the Caribbean Sea, and are thought to be responsible for a growing anoxia problem (Goolsby et al., 2000). A more chronic problem for the drinking water community is the persistent and increasing occurrence of pathogens in raw drinking water, which requires extensive oxidative or chlorinated treatment. However, parameters such as dissolved organic carbon (DOC) limit the amounts of chlorination due to simultaneous disinfection by-product formation.

Regulating non-point source pollutants proves to be difficult since specific dischargers are difficult to identify. More recent amendments to the CWA (section 319) in 1987 provides a regulatory basis to address non-point source pollution. However, processes generating non-point source pollutants are not well understood or are controversial, and typically they are poorly constrained geographically.

The concept of watershed management has gained much ground over the years as a means to resolve non-point source problems. Under this management scheme stakeholders in a watershed collectively agree to the nature and extent of non-point sources, determine water quality causes using sound scientific approaches, and together develop and implement a corrective plan. However, the "science" of watershed management currently has several shortcomings according to a recent National Research 
Council report (NRC, 1999). Among them is a lack of interdisciplinary science approaches conducted at appropriate spatial and temporal scales that could be used to facilitate decision-making within a watershed management framework. Consequently, much of the regulatory focus is still at the point of treatment.

A good example of the current focus at the treatment point includes the rising concern over pathogen occurrence in raw drinking water. This has promulgated the proposed regulatory framework of microbial/disinfectant and disinfection byproduct rules. The initial concern was actually health effects associated with disinfection byproduct formation during chlorination, but outbreaks of pathogens such as Cryptospiridium in public drinking water broaden the scope to microbial reduction. The rule-making process is incremental beginning with the Information Collection Rule (ICR). This required major utilities to collect 18 months of water quality data for microbial and disinfection byproduct occurrences. The next incremental action is the formation of a formal advisory committee to assess the data collected under the ICR, and the available health affects data and attempt to agree on regulation guidelines. Possible guidelines may include alternate oxidative treatment methods such as ozonation, utilization of membrane filtration steps, better source water protection, and reduction of total organic matter concentrations before chlorination. All of these outcomes equate to increased costs at the point of treatment. However, some of these costs could be offset if utilities better understood the watershed processes controlling water quality at the treatment point. This better understanding could at least enhance the predictability of time periods where poorer water quality occurs and allow flexibility in daily operational procedures and reduce annual costs. 


\section{Study Objectives}

This study tested whether isotope measurements of surface water and dissolved constituents in surface water could be used as tracers of non-point source pollution. Oxygen-18 was used as a water tracer, while carbon-14, carbon-13, and deuterium were tested as tracers of DOC. Carbon-14 and carbon-13 were also used as tracers of dissolved inorganic carbon, and chlorine-36 and uranium isotopes were tested as tracers of other dissolved salts. In addition, large databases of water quality measurements were assembled for the Missouri River at St. Louis and the Sacramento-San Joaquin Delta in California to enhance interpretive results of the isotope measurements. Much of the water quality data has been under-interpreted and provides a valuable resource to investigative research, for which this report exploits and integrates with the isotope measurements.

\section{$\underline{\text { Significance }}$}

The proposed regulatory framework surrounding the reduction of pathogens and disinfection byproduct formation during drinking water treatment will ultimately incur greater cost at the point of treatment. The requirement to employ the best available technology, which may include filtration media or alternatives to chlorination, places the emphasis on the utility. However, the source of these current problems in raw drinking water quality may in many cases stem from landuse activities within the watershed. Therefore, studies that focus on developing a better understanding of watershed processes that generate or further deteriorate stream or river water quality have long-range benefit to drinking water utilities. In particular, a better understanding provides a basis for better 
prediction of water quality, and a stronger foundation for any mitigation strategies to reduce water quality problems in a watershed management approach.

\section{Research Approach}

\section{Background on Watershed Water Quality}

Early water quality concerns in surface waters date back to the $19^{\text {th }}$ century when raw sewage was routinely discharged to a water system from large urban/industrial areas with little regard to downstream use. With recognition of the link between this pollution and water borne disease, the subsequent adoption of sand filtration and chlorination by the drinking water producers alleviated the health and water quality concern. It wasn't until the 1950s and 1960s that urban/industrial expansion achieved a size, where high biological oxygen demand (BOD) in raw sewage discharge affected the oxygen balance in rivers and lakes, that national level action was taken to regulate pollution discharge. Prior to and with the adoption of the Clean Water Act in 1972, regulated discharge was initiated, and public financing was available to treat waste before entering the stream. This included actions such as BOD reduction, and metals removal, but also changes to commercial products to reduce elements such as phosphorus, which caused, along with nitrogen, eutrophication. Additional actions included commercial changes to product formulations to reduce synthetic chemicals in waste water discharge, for example surfactants (Swisher, 1987). These actions did much to restore the ecological health of watershed systems and reduce the risk to drinking water consumers. Concerns from urban and industrial waste water discharge that are persistent today are nitrogen levels, dissolved salts, and in some cases risk from viruses (Meybeck et al., 1990). 
An early non-point source pollution concern was high suspended loads in rivers, which was typically associated with increased nutrient and pollutant loads, leading to increased photosynthetic growth and eutrophication in large water bodies (e.g. Laws, 1993).

Consequently, filtration and settling times increased for drinking water treatment. Besides suspended particulates from urban sewage discharge, much of the sediment was due to enhanced erosion caused by farming, logging, and mining, which increased sediment yields 20 to 50 times above natural levels (Meybeck et al., 1990). Erosion abatement programs on farms have done much to reduce this problem, and lock or dam construction on most of our major rivers have inadvertently reduced suspended loads.

Nitrogen has been a persistent non-point source water quality concern in surface water since the late 1960 s (e.g. Novotny and Chesters, 1981), particularly where levels were high enough to cause large-scale eutrophication. For example, annual nitrogen discharge from the Mississippi River is $1.4 \times 10^{9} \mathrm{~kg} / \mathrm{yr}$, and is thought to be high enough to cause hypoxia in the Gulf of Mexico (Malakoff, 1998; Goolsby et al., 2000). Much of the nitrogen source is blamed on excess agricultural fertilizers annually discharging to streams. As a result, large-scale mitigation strategies have been proposed to alleviate this problem, including restoration of 5 million acres of natural wetlands to riparian corridors comprising the Mississippi drainage (NSTC, 2000). Wetland development would have the added benefit of suspended sediment control.

Equally valid concern over increasing herbicides and insecticides in river discharge in the past 15 years has resulted in proposed regulatory limits (e.g. Stamer, 1996), but the wide-spread use of these chemicals and seasonal occurrence (Thurman et al., 1991; Kuivila and Foe, 1995) makes them difficult to regulate at the source. 
More recent concern has been focused on microbial risk to drinking water consumers, particularly with high profile cases in recent history such as the Cryptosporidium outbreak in Milwaukee (e.g. Mac Kenzie et al., 1994), and widespread occurrence of Pfisteria in the Chesapeake Bay (e.g. Tibbetts, 1996).

Previous studies of water quality in surface waters can be separated into different focus areas pursuing distinct and independent goals. For example, research focused on utility drinking water quality typically utilizes engineering or chemistry approaches, whereas when water quality affects aquatic life, the research approach is more from ecological discipline, which has no traditional link to drinking water concerns. Likewise, geochemical-based studies of riverine systems primarily have been concerned about erosion, climate change, and acidification processes. However, watershed management of water quality benefits from research and input from all these disciplines. The distinction among these different types of research is made because the available published literature tends to reflect these disparate research emphasis. For example, many previous studies using geochemical approaches, where research questions mainly focused on solute transport, typically sampled over a large geographic area in a short timeframe. Unfortunately, for drinking water quality interests, such an approach does not serve the need for seasonal and inter-annual trend analysis necessary for determining, for example, water quality treatment methods or understanding sources of pollutants. This is most prevalent in previous studies that utilize isotope analysis in watershed studies. The study of natural isotope abundances is traditionally a geochemical discipline and has rarely been used in engineering-based investigations. Consequently, very little isotope studies have been conducted with the specific intent of understanding aquatic pollutants. 
In this study, we examine the chemical and oxygen isotope variations of the lower Missouri River using data collected daily to monthly over the last five years. We show how several parameters respond to several seasonal cycles, a major flood, and an intense ENSO event. We also show how the daily chemical measurements can be combined with discharge records to resolve Missouri River water into distinct geographic components. Our approach provides insight into Missouri River water quality dynamics and clues on how to better predict drinking water quality.

\section{Surface Water Geochemistry}

Geochemical methods provide important tools for the elucidation of river dynamics, however, most studies published in the open literature have used ionic concentrations in river water to either answer questions regarding continental erosion or effects of acid rain. Early studies of river systems focussed on sources of solutes at global scales to elucidate the predominant reaction pathways to continental erosion (Garrels and Mackenzie, 1971). At this scale, surface water chemistry is easily defined geochemically by sources comprising atmospheric precipitation, rock erosion, and evaporative enrichment (Gibbs, 1970). At river basin scales, the geochemical character of surface water is dominated by regional geological formations, climate, and effects of ocean aerosol deposition (Reeder et al., 1972; Stallard and Edmund, 1981). Much recent attention on geochemical balances has been directed to relatively small-scale catchments, in order to better understand long term anthropogenic effects (Driscoll, 1989). It is typical for these studies to focus on the hydrochemical responses of small systems over short, post-storm time scales (Moldan and Eern, 1994). 


\section{Definition, Discovery, and Uses of Isotopes}

The word "isotope" has a Greek origin meaning "same place". This accurately describes the occurrences of atoms of the same element having different masses, or atoms with the same number of protons, but different number of neutrons. Hints of these mass differences began to emerge in the late 1800 's as chemists were rapidly discovering new elements with assigned atomic numbers, and filling in the periodic table conceived by Mendeleev. However, careful mass determinations, particularly of heavier elements, ultimately revealed non-integer atomic mass values for most elements rather than whole numbers reflected by atomic numbers. These observations directly challenged the accepted theory of atomic indivisibility developed by John Dalton in the early 1800 's. In 1914, Frederick Soddy proposed that elements comprised "isotopes" of the same atoms to explain the mass discrepancies. Evidence for isotopes were first observed by J.J. Tomson, who using essentially a modified cathode ray tube, showed that neon comprised two different isotopes, defined by their mass-dependent dispersion within the electrostatic field of his proto-mass spectrometer. Ernest Rutherford is credited for determining the size and electronic state of atoms, however it wasn't until 1932 that James Chadwick, while working in Rutherford's lab, discovered neutrons as a separate and neutral particle to explain the discrepancies between atomic mass (neutrons + protons) and atomic number (protons). This also explained nuclear instability for higher mass elements that exhibit spontaneous radioactive decay, which was actually first discovered in the 1890 's. At this point, the atomic picture was complete and this gave rise to most of the current theories and experimental confirmation of nuclear fission and fusion, most inauspiciously demonstrated by development and testing of atomic weapondry during and after WWII. 
Besides nuclear weapons, isotopes have many important uses today, including generation of electricity in nuclear power plants, medical imaging and radiation therapy, luminescent displays, and reaction path tracers in medical, biological, agricultural, and chemical research sciences. After WWII, a field of natural isotope sciences began to emerge, most notably a group of post-docs under Harold Urey, that began to observe natural isotopic variations of the earth and the solar system. Natural chemical reactions in the solar system and in terrestrial systems that give rise to chemical separation and enrichment also, in many cases, have underlying isotopic partitioning reactions that provide natural tracers or fingerprints of these processes. It is this latter knowledge that is utilized in this particular report.

Natural chemical reactions in nature that give rise to phase changes or chemical speciation of an element or combination of elements also cause isotopic partitioning reactions, particularly for low mass elements (e.g. hydrogen through sulfur). These partitioning reactions are known collectively as isotopic fractionation. In most cases, isotopic fractionation of low-mass elements preferentially enriches the higher mass isotope in the more solid or thermodynamically stable phase. This arises because the vibrational energy of chemical bonds are directly proportional to their frequency, which in turn is inversely related to the reduced mass

$$
\mu=\frac{m_{1} m_{2}}{m_{1}+m_{2}}
$$

where $m_{I}$ and $m_{2}$ are atomic mass units of two different isotopes of the same element. The higher the reduced mass, the lower the vibrational frequency, however, more importantly, the larger the ratio of reduced masses between two different isotopes of the same element, the larger the isotopic fractionation, 


$$
\frac{v_{1}}{v_{2}}=\sqrt{\frac{\mu_{2}}{\mu_{I}}}
$$

where $v$ is the vibrational frequency. Although chemical bond strength is determined by the interaction of the atomic electronic shells, the vibrational energy differences are the basis for isotopic fractionation reactions in nature. For example, the vapor pressure of pure $\mathrm{D}_{2} \mathrm{O}$ ("heavy water") is approximately $15 \%$ lower at $25^{\circ} \mathrm{C}$ than that of $\mathrm{H}_{2} \mathrm{O}$. More exact mathematical definitions of isotopic fractionation are beyond the scope of this brief discussion, but the interested reader is referred to Criss (1999) for a thorough discussion.

Biological systems also fractionate the isotopic abundance of low-mass elements. In this case, the isotopic fractionation is a non-equilibrium process that mostly depends on kinetic rate processes of enzymatic reactions during metabolism. In general, autotrophic organisms (i.e. plants and many bacteria) are responsible for the largest observed isotopic fractionation factors in hydrogen, carbon, and oxygen (e.g. Smith and Epstein, 1971; Epstein et al., 1977; DeNiro and Epstein, 1979), whereas heterotrophs exhibit smaller fractionations.

Many higher mass elements commonly exhibit spontaneous radioactive decay, and above mass 209 , no stable isotopes of elements exist for the so-called "heavy elements". Radioactive decay is due to nuclear instability of the atom, manifested by ejection and incorporation of energized subatomic particles from the nucleus (e.g. gamma, beta, alpha particles) in order to reach a more stable energy state. The rate of decay for any radioisotope is constant, following a well known radioactive decay expression

$$
\frac{N}{N_{o}}=e^{-\lambda t}
$$


where $N$ is the instantaneous abundance of a radioactive element, $N_{o}$ is its initial abundance, $\lambda$ is the decay constant, and $t$ is time. The decay constant can easily be related to the time when half the original abundance has been decayed (half-life, or $T_{1 / 2}$ ) by $T_{1 / 2}$ $=\ln 2 / \lambda$. It is common to refer to the decay rate in terms of its half-life. For example, uranium has three primary isotopes $\left({ }^{234} \mathrm{U},{ }^{235} \mathrm{U}\right.$, and $\left.{ }^{238} \mathrm{U}\right)$, all of which are radioactive. Nevertheless; their half-lives are 246,000 years for ${ }^{234} \mathrm{U}, 700 \times 10^{6}$ years for ${ }^{235} \mathrm{U}$, and $4.5 \times 10^{9}$ years for ${ }^{238} \mathrm{U}$. This is also the order of their abundance on earth for obvious reasons. These natural isotopes originated during the nuclear synthesis of the solar system, and their slow decay rates have ensured their relative ubiquity on earth even several billion years later. The entire decay chain sequence for uranium isotopes is complex, but its ultimate decay products are stable lead isotopes. Stable isotopes produced from decay of radioisotopes are known as daughter products. The isotopic ratio of ${ }^{234} \mathrm{U} /{ }^{238} \mathrm{U}$ and ${ }^{235} \mathrm{U} /{ }^{238} \mathrm{U}$ have useful diagnostic properties for age-dating of old rocks and for groundwater. Other well understood examples of natural radioactive isotopes are ${ }^{3} \mathrm{H}\left(\mathrm{T}_{1 / 2}=12.4 \mathrm{yrs}\right)$ and ${ }^{14} \mathrm{C}\left(\mathrm{T}_{1 / 2}=5730 \mathrm{yrs}\right)$, both of which have been studied and used extensively in the hydrologic sciences. The reader is referred to Faure (1986) for more detailed discussion of isotope geology theory and application

\section{Principles of Oxygen-18 and Deuterium as Tracers in Surface Water}

Oxygen and hydrogen comprising water molecules both have isotopes with different masses. Oxygen-18 $\left({ }^{18} \mathrm{O}\right)$ is a stable isotope (non-radioactive) of oxygen that represents approximately $0.2 \%$ of all oxygen atoms on earth, while deuterium $\left(D\right.$ or $\left.{ }^{2} \mathrm{H}\right)$ is a stable isotope of hydrogen representing about $0.02 \%$ of all hydrogen atoms. These isotopes are 
typically compared to the more common isotopes of oxygen- $16\left({ }^{16} \mathrm{O}, 99.8 \%\right)$ and protium $(\mathrm{H}, 99.98 \%)$, respectively. The routine measurement of isotope abundances is accomplished by mass spectrometers, an instrument that applies an electronic potential and acceleration to charged particles and induces an orthogonal magnetic field to achieve particle dispersion as a function of mass. For stable isotope mass spectrometry, purified gases are ionized and isotopic abundances are measured as a ratio to a know standard and converted by the equation

$$
\delta=\left(\frac{R}{R_{\text {std }}}-1\right) 1000
$$

where $R$ is the isotopic ratio of either $\mathrm{D} / \mathrm{H},{ }^{18} \mathrm{O} /{ }^{16} \mathrm{O}$, or ${ }^{13} \mathrm{C} /{ }^{12} \mathrm{C}$, Rstd is the isotopic ratio of a known standard, and the $\delta$ (pronounced "del") value is the operational name proceeding the isotopic species.

The isotopic abundance of ${ }^{18} \mathrm{O}$ and deuterium has a pronounced variation among different terrestrial waters, and observations of this abundance for the past 60 years have given rise to many important works on underlying mechanisms controlling the hydrologic cycle. The ${ }^{16} \mathrm{O}$ atom in an $\mathrm{H}_{2}{ }^{16} \mathrm{O}$ molecule has a higher vibrational bond energy than ${ }^{18} \mathrm{O}$ in an $\mathrm{H}_{2}{ }^{18} \mathrm{O}$ molecule, and therefore the latter has a higher affinity to and abundance in lower energy states (i.e. liquid and ice). The same applies to hydrogenated and deuterated water molecules, although the magnitude of the isotopic fractionation is greater because of the large reduced mass difference between hydrogen and deuterium. The isotopic fractionation of $\delta^{18} \mathrm{O}$ and $\delta \mathrm{D}$ values in natural water is ultimately governed by the temperature during water evaporation and condensation. As such, large isotopic variations are observed geographically as a function of latitude and altitude (e.g. Epstein 
and Mayeda, 1953; Craig, 1961; Dansgaard, 1964). Storm systems migrating over the continent are essentially closed hydrologic systems. Sequential loss of cloud water with time in these storm systems, combined with isotopic fractionation, cause an isotopic distillation effect. Therefore during continental migration of storm tracks heavier isotopes are preferentially depleted with distance and time (Figure 1; e.g. Dansgaard, 1964;

Sheppard, 1986).

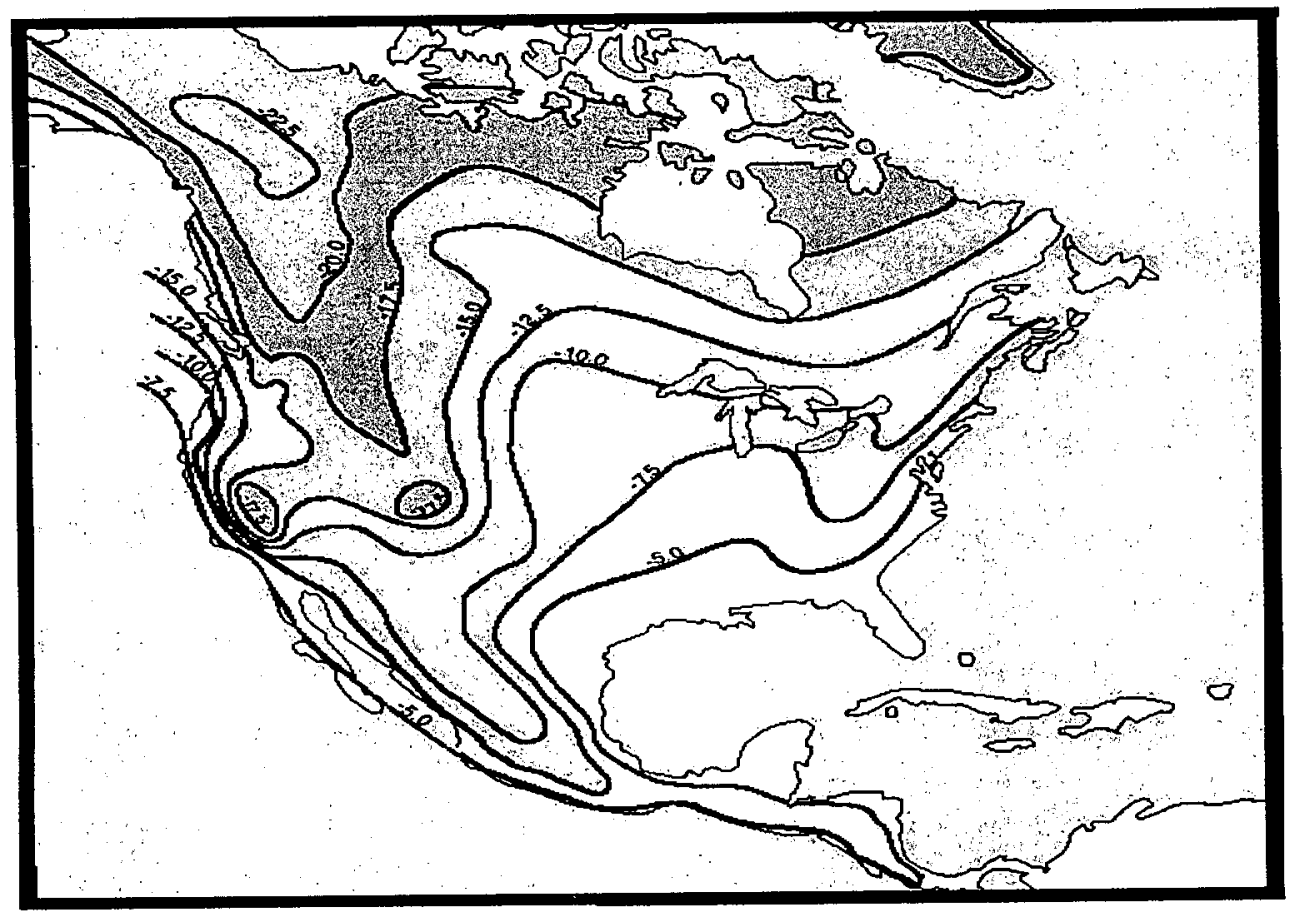

Figure 1. Mean annual $\delta^{18} \mathrm{O}$ values for surface water and precipitation in North America is controlled by latitude, elevation, and distance from coastal areas (after Taylor, 1974)

The global meteoric water line (MWL) of $\delta \mathrm{D}=8 \delta^{18} \mathrm{O}+10(\mathrm{Craig}, 1961)$ reflects the isotopic abundance of water vapor condensed under isotopic equilibrium at different temperatures, and/or during progress of the distillation effect in single storm systems. The slope, and the y-intercept (i.e. deuterium excess), results, respectively, from the relative fractionation of $\mathrm{D} / \mathrm{H}$ and ${ }^{18} \mathrm{O} /{ }^{16} \mathrm{O}$ between water liquid and vapor, and from kinetic isotope fractionation between water and water-vapor evolving over the open 
ocean (Craig and Gordon, 1965). Continental surface water and shallow groundwater also undergoes kinetic isotope enrichment during evaporation, and liquid water isotopic values enrich along trajectories with slopes between 2.0 and 6.0 on a $\delta \mathrm{D}-\delta^{18} \mathrm{O}$ plot (Craig et al., 1963; Stewart, 1975; Barnes and Allison, 1988).

The continental variation in $\delta \mathrm{D}$ and $\delta^{18} \mathrm{O}$ values are reflected strongly in river water (Friedman et al., 1964; Ramesh and Sarin, 1992). Large river systems, such as the Missouri River, originate in high elevation regions of the Eastern Rocky Mountains, where melting snow contributes runoff with low deuterium and ${ }^{18} \mathrm{O}$ abundances, whereas lower elevation watersheds in the states of Nebraska, Kansas, and Missouri contribute runoff to the Missouri River with higher abundance. Although inter-seasonal variations in the mean isotopic value can occur (Friedman and Smith, 1972; Criss et al., 2001), the large spatial variation in source areas of large river systems dominates the isotopic signature.

Isotopic abundances of deuterium and ${ }^{18} \mathrm{O}$ can vary significantly between and within different storm events, and appears to be related to mean air temperatures during the storm and storm sources (Friedman et al., 1964; Lawrence et al., 1981). These inter-storm variations have been exploited in small watershed studies to delineate groundwatersurface water interaction in stream runoff (Sklash and Farvolder, 1979; Pionke et al., 1993; Fredrickson and Criss, 1999). Because groundwater tends to homogenize the interstorm isotopic variability, its contribution to stream flow will be distinguishable from surface runoff originating from a single storm. This dynamic relationship has recently been exploited as a groundwater dating tool (Fredrickson and Criss, 1999). 
Since water evaporation preferentially enriches the liquid phase in both deuterium and ${ }^{18} \mathrm{O}$, a good linearity exists between salinity and isotopic abundance (Friedman et al., 1964; Craig and Gordon, 1965). This relationship has been used to trace sources of salinity in surface and ground water investigations (Payne et al., 1979; Simpson and Herzeg, 1991; Lambs, 2000; Criss et al., 2001).

\section{Other Isotope Tracers Used in Surface Water Investigations}

\section{Nitrogen}

Nitrate concentration is regulated as a primary contaminant in raw drinking water at $10 \mathrm{mg} / \mathrm{L}$ as $\mathrm{N}$. Increased nitrate concentration in major rivers due to human activity around the world impacts the nutrient balance in stream riparian habitats and in coastal ecosystems (Peierls et al., 1991). For example, Goolsby et al. (2000) argue that nitrate in the Mississippi River has increased 2 to 5 fold in the past 100 years, and is largely responsible for the annual hypoxia occurrence in the Gulf of Mexico. They contend the majority of the nitrogen originates from fertilized farmlands of the Midwestern states. Similar observations and conclusions are made for smaller-scale basins in the northeastern US (e.g. Cronan et al., 1999). In addition, atmospheric deposition of nitrate and ammonia are, respectively, implicated in acid rain increases in the northeastern US and a contributor to nitrogen loading in the Mississippi River (e.g. Lawrence, 1999). Similar arguments for nitrogen loading have been cited for sewage discharge (e.g. Chesterikoff et al., 1992).

Most of the earth's nitrogen resides in the atmosphere $\left(3.5 \times 10^{18} \mathrm{~kg}\right)$ and the earth's crust $\left(1.8 \times 10^{18} \mathrm{~kg}\right)$, whereas nitrogen residing in the hydrosphere and soils together represent a significantly smaller reservoir $\left(\sim 4.0 \times 10^{15} \mathrm{~kg}\right)$. However, the nitrogen in this 
latter reservoir is in a constant state of flux, undergoing oxidation and reduction processes during nutrient uptake and recycling. Nitrogen is usually found in soil and water as nitrate, nitrite, ammonium, and amino acids, with the majority as either nitrate or ammonium. In natural systems, soil nitrogen is ultimately derived from the atmosphere by nitrogen-fixing organisms, following a path of protonation to diimide, and then ammonia, ammonium, and finally amino acids. These reduced forms of nitrogen are oxidized into nitrate upon release from plants. Nitrate either is reduced back to ammonia by assimilative organisms, or it is denitrified by microbial respiration as nitrous oxide or nitrogen gas.

Nitrogen has two stable isotopes of ${ }^{15} \mathrm{~N}(0.37 \%)$ and ${ }^{14} \mathrm{~N}(99.63 \%)$. The utility of an enriched ${ }^{15} \mathrm{~N}$ tracer has long been recognized in the agricultural and biological sciences. However, the exploitation of natural ${ }^{15} \mathrm{~N} /{ }^{14} \mathrm{~N}$ ratios as an environmental tracer has received mixed results. Early work by Kohl et al. (1971) measured differences in the $\delta^{15} \mathrm{~N}$ abundance of dissolved nitrate in stream water and attributed them to a mixture between natural and agricultural fertilizer sources. Their simple two end-member model was criticized by Hauck et al. (1972) for underestimating the complexities of ${ }^{15} \mathrm{~N}$ fractionation process in the soil environment. These fractionations result from assimilation of nitrate to ammonia and denitrification of nitrate to nitrogen or nitrous oxide. There is a small isotopic isotopic fractionation during nitrogen fixation also. Below are ranges of isotopic differences observed for nitrogen isotopic fractionation under these conditions. Values are shown as epsilons $(\varepsilon), \varepsilon=\left(R_{1} / R_{2}-1\right) 1000$, where $R_{1}$ is the isotopic ratio of one chemical species and is compare to the isotopic ratio of another species $\left(R_{2}\right)$ for which it exchanges. 
Assimilation of Nitrate or Nitrite

Micro-organisms

Higher Plants

Denitrification of Nitrate to $\mathrm{N}_{2}$ or $\mathrm{N}_{2} \mathrm{O}$

Nitrogen Fixation

*Values derived from tables in Hübner (1986) $\varepsilon *$ per mil

-9.7 to +45

-1.7 to +0.6

+1.9 to +19.1

-3.7 to +3.9

A positive $\varepsilon$ value indicates an isotopic enrichment in the reactant, whereas a negative value represents a depletion. Note that the most significant fractionations for ${ }^{15} \mathrm{~N}$ are in micro-organism assimilation reactions and in the denitrification processes. Most biological fractionation prefers to enrich ${ }^{14} \mathrm{~N}$, as can be seen by positive $\varepsilon$ values for most assimilation and denitrification reactions. However, these processes tend to be reactant limited, and as a result, nitrogen species react under near-closed conditions. Because isotopic mass must be conserved in closed reaction conditions, mean $\delta^{15} \mathrm{~N}$ values of total nitrogen will not change significantly. For example, most soil $\delta^{15} \mathrm{~N}$ values are only modestly enriched over air ( 0 per mil) typically varying between -2 and +10 per mil (e.g. Letolle, 1980; Kendall, 1998). Because most artificial fertilizers have $\delta^{15} \mathrm{~N}$ values near that of air (Hübner, 1986), fertilized soils do not differ dramatically from natural soil nitrogen. Denitrification is somewhat common in saturated groundwater, and as such, $\delta^{15} \mathrm{~N}$ enrichments of nitrate correlate well with nitrate concentration, reflecting the closed nature of the nitrogen reduction (e.g. Kreitler, 1983, Heaton, 1986).

A few studies in surface water using $\delta^{15} \mathrm{~N}$ as a tracer of nitrogen sources observed similar trends as Kohl et al. (1971). In these studies, it is common for small watersheds with multiple nitrogen sources to have near uniform $\delta^{15} \mathrm{~N}$ values, except for a marked ${ }^{15} \mathrm{~N}$-depletion during storm runoff and soil flushing, and a distinct ${ }^{15} \mathrm{~N}$-enrichment during baseflow (e.g. Mariotti et al., 1975). It has been postulated that this isotopic enrichment is 
due to ammonium volatilization in the soil (e.g. Kreitler and Jones, 1973; Hübner, 1986). McMahon and Bohlke (1996) argued that large-scale denitrification in the soil/aquifer system contribute to enriched $\delta^{15} \mathrm{~N}$ in stream water. Other work has shown nitrification and denitrification from point sources discharged to surface water contributed to large and significant isotopic enrichments in residual nitrogen species with distance downstream or time (e.g. Lindau et al., 1989; Ii et al., 1997).

More recently simultaneous measurements of the $\delta^{15} \mathrm{~N}$ and the $\delta^{18} \mathrm{O}$ values of nitrate have provided a dual tracer of nitrogen sources and processes. Most revealing are data from alpine snow packs, where nitrates are highly enriched in $\delta^{18} \mathrm{O}$ (up to +70 per mil) due to fallout from atmospheric sources (Durka et al., 1994). The dual isotope measurement has also provided a robust quantitative approach for identifying and tracking groundwater denitrification reactions (Wassenaar, 1995). However, soil nitrification usually entails a hydration reaction, and the $\delta^{18} \mathrm{O}$ value of the nitrate does not differ significantly from the soil water (Durka et al., 1994), leaving only the ${ }^{15} \mathrm{~N}$ as a qualitative indicator.

Because of the complexities inherent in nitrogen istope measurements and interpretation, and based on limited success of previous work in surface water, this type of isotopic analysis was not performed for this study. Under well defined and controlled conditions, nitrogen isotopes can be diagnostic of sources and process in a semiquantitative manner. However, for the scope of this research, which is more reconnaisssance in nature, the nitrogen isotope measurements would have provided only qualitative information at best. This statement is further validated by recent results of 
$\delta^{15} \mathrm{~N}$ and $\delta^{18} \mathrm{O}$ measurements of nitrate in the lower Mississippi River that did not yield any difinitive results (Kendall et al., 1999).

\section{Inorganic Carbon-13}

Carbon has two stable isotopes ${ }^{12} \mathrm{C}(99 \%)$ and ${ }^{13} \mathrm{C}(1 \%)$. Most of the earth's terrestrial carbon is fixed in reduced forms in the biosphere (ignoring coal and oil). The remaining carbon is typically in oxidized forms as carbonates in rocks and soils, or as dissolved inorganic forms in water, the ocean being the largest reservoir of this form. Dissolved organic carbon (DOC) is also an important component, but is discussed in a later section. All terrestrial carbon fixed in inorganic or organic forms originates from atmospheric $\mathrm{CO}_{2}$. Modern atmospheric $\mathrm{CO}_{2}$ has a $\delta^{13} \mathrm{C}$ value of around -8.0 per mil (Keeling et al. 1989). $\mathrm{CO}_{2}$ uptake by land plants results in isotopic fractionation of the ${ }^{13} \mathrm{C}$ between -20 and -30 per mil for plants utilizing the $\mathrm{C} 3$ pathway of photosynthesis. $\mathrm{C} 4$ plants have a smaller fractionation about half that of C3 plants (Smith and Epstein, 1971). Whole C3 plant material typically averages -28 per mil, while $\mathrm{C} 4$ plants average -13 per mil (e.g. Deines, 1980). Corn and other grasses are common C4 plants and have characteristically higher $\delta^{13} \mathrm{C}$ values than most trees for example.

Land plants respire $\mathrm{CO}_{2}$ through their roots, which for $\mathrm{C} 3$ plants the $\delta^{13} \mathrm{C}$ of the $\mathrm{CO}_{2}$ is between -25 and -28 per mil. This elevates the partial pressure of $\mathrm{CO}_{2}$ in the soil environment. Additional $\mathrm{CO}_{2}$ in the soil is derived from oxidized organic matter. Soil $\mathrm{CO}_{2}$ is hydrated to carbonic acid and bicarbonate by soil water and by base reaction with carbonate and silicate minerals. The dissolution of $\mathrm{CO}_{2}$ into bicarbonate results in a net $\delta^{13} \mathrm{C}$ enrichment in the bicarbonate between 7 and 10 per mil (e.g. Mook, 1980). With 
additional carbon added from carbonate mineral dissolution, the $\delta^{13} \mathrm{C}$ of soil and shallow groundwater of neutral $\mathrm{pH}$ typically ranges between -12 and -18 per mil beneath plants of $\mathrm{C} 3$ character. Higher values are expected for groundwater water beneath $\mathrm{C} 4$ plants (see data in Clarke et al., 1998). These isotopic values for shallow groundwater generally reflect partial to complete isotopic equilibrium with soil $\mathrm{CO}_{2}$ respired from plants.

If a surface water were exposed to the atmosphere for a long period of time, then its DIC would isotopically equilibrate with atmospheric $\mathrm{CO}_{2}$, and the expected $\delta^{13} \mathrm{C}$ would be -1 to +2 per mil (e.g. Mook and Tan, 1991). Ocean water is a good example since its $\mathrm{DIC} \delta^{13} \mathrm{C}$ value averages $\sim 0$ per mil. Consequently, the dissolved inorganic carbon (DIC) in continental surface water will range between soil water values of -18 per mil, up to around 0 per mil for waters in isotopic equilibrium with atmospheric $\mathrm{CO}_{2}$ (e.g. Mook and Tan, 1991). These differences have been further exploited recently in the Rhone River system, where DIC ( $1 \mathrm{mM}$ to $3.8 \mathrm{mM}$ ) inversely correlated with $\delta^{13} \mathrm{C}$ values $(-5$ to -11 per mil; Aucour et al., 1999). The upper watershed had low DIC, where inorganic carbon was fixed by non-respiration processes, while the lower watershed showed increased DIC and lower $\delta^{13} \mathrm{C}$ values from soil respired $\mathrm{CO}_{2}$ sources. Temer and Veizer (1999) noted that consistently low $\delta^{13} \mathrm{C}$ values $(-8$ to -16 per mil) for DIC in the Ottawa River signified that respired $\mathrm{CO}_{2}$ was the main source of DIC, atmospheric exchange was insignificant, and autotrophic use of DIC did not appreciably affect the river's carbon budget. 


\section{Strontium and Uranium Isotopes}

Strontium is another example of stable isotopes formed as radioactive decay products (i.e. daughters). The stable isotope ${ }^{87} \mathrm{Sr}$ originates as a decay product of ${ }^{87} \mathrm{Rb}$, whose halflife is $48 \times 10^{9}$ years. The stable isotope ratio of ${ }^{87} \mathrm{Sr} /{ }^{86} \mathrm{Sr}$ is commonly used to date old rocks, and have provided the most reliable estimates for the age of the earth. In addition, $\mathrm{Rb}$ is an alkaline earth element and easily substitutes for $\mathrm{K}$ in rock minerals. Therefore, K-bearing minerals tend to have high ${ }^{87} \mathrm{Sr} /{ }^{86} \mathrm{Sr}$ ratios, whereas $\mathrm{Ca}-\mathrm{Mg}$ dominated rocks such as marine carbonates tend to have much lower ratios. These differences have been used to distinguish between marine versus continental sources of $\mathrm{Sr}$ in ocean water through geologic time (Burke et al., 1982). This has lead to several studies of sources and isotopic character of continental erosion and transport of suspended material to the ocean by rivers (e.g. Wadleigh et al., 1985; Palmer and Edmond, 1992). In smaller scale river studies, the ${ }^{87} \mathrm{Sr} /{ }^{86} \mathrm{Sr}$ ratio measurement has aided in the source delineation of dissolved loads (e.g. Douglas et al., 1995; Semhi et al., 2000; Grosbois et al., 2000).

The ${ }^{87} \mathrm{Sr}{ }^{86} \mathrm{Sr}$ ratio has also been used to discriminate preferential mineral hydrolysis among mineral mixtures in rocks and soils (e.g. Bullen et al., 1997). The effect of this differential hydrolysis has been noted in snowmelt stream waters of the Sierra Nevada Mountains in California (Blum et al., 1994). The ${ }^{87} \mathrm{Sr} /{ }^{86} \mathrm{Sr}$ ratio has been used to measure the rate at which shallow groundwater recharge reacts towards chemical equilibrium with the aquifer mineralogy, and mixing with other recharge sources (e.g. Bullen et al., 1996). Because $\mathrm{Sr}$ is a divalent cation, it also serves as a proxy and tracer of other major divalent cations such as $\mathrm{Ca}$, and therefore has been explored as a nutrient tracer in small catchments (Bullen and Kendall, 1998). The successful use of Sr isotopes as a tracer in 
river studies depends on understanding rates of mineral hydrolysis and progression toward thermodynamic equilibrium in stream inorganic chemistry. This will depend on the "age" of the surface water (e.g. fresh alpine snowmelt versus floodplains) and some prior knowledge of basin geologic age.

Uranium in continental rivers is mostly generated by exposed carbonate rocks, and in some cases black shales, and its flux to world oceans has been characterized (Palmer and Edmond, 1993). The uranium isotopic abundance in natural water has generated much interest and debate over the years, mostly because of the complex radioactive decay chain of the uranium isotopes, and the chemical behavior of intermediate radiogenic daughters. For example, ${ }^{238} \mathrm{U}$ decay by alpha emission forms ${ }^{234} \mathrm{Th}$ at a constant rate. Subsequently, the ${ }^{234} \mathrm{Th}$ decays by beta emission to ${ }^{234} \mathrm{U}$ at a decay rate greater than ${ }^{238} \mathrm{U}$ (e.g. $\mathrm{T}_{1 / 2}$ for ${ }^{234} \mathrm{Th}=24.1$ days). Therefore, a secular equilibrium is formed among these three isotopes. It is thought that during ${ }^{238} \mathrm{U}$ decay, the energetic alpha emission, or alpha recoil, damages crystalline sites in minerals, so that subsequent formation of ${ }^{234} \mathrm{U}$ is more readily solubilized from a mineral surface (Ivanovich and Harmon, 1982). Th also has a low aqueous solubility compared to $\mathrm{U}$, and is likely scavenged readily from the aqueous environment during aqueous ${ }^{238} \mathrm{U}$ decay. This differential solubility due specifically to alpha recoil causes high ${ }^{234} \mathrm{U}{ }^{238} \mathrm{U}$ isotopic ratios in natural groundwater (e.g. Osmond and Cowart, 1982), whereas the source of $U$ (e.g. soil or rock) will maintain its natural ${ }^{234} \mathrm{U} /{ }^{238} \mathrm{U}$ isotopic ratio. The ${ }^{234} \mathrm{U} /{ }^{238} \mathrm{U}$ isotopic ratio is commonly converted to an activity ratio, where a ratio of 1.0 represents a natural uranium source, and a ratio $>1.0$ typically results from alpha recoil effects (i.e. in groundwater). 
Snow and Spalding (1994) measured ${ }^{234} \mathrm{U} /{ }^{238} \mathrm{U}$ ratios in the Platte River to delineate uranium sources. The activity ratios in Platte River were high ( 1.70) during baseflow and low (down to 1.03) during high flow. These differences were due to groundwater sources with high ratios dominating discharge during low flow periods, and surface runoff with low ratios during high flow periods. Presumably, the runoff recently leached uranium from a source with an activity ratio near unity. However, the workers also suggested that uranium in phosphate fertilizers would also have similarly low activity ratios, and due to previous observations of high nitrates in the river, concluded that fertilizers were also a potential uranium source. Subsequent work by Zielinski et al. (1997) in southeastern Colorado showed that uranium and nitrate were decoupled in stream water, and that the low ${ }^{234} \mathrm{U} /{ }^{238} \mathrm{U}$ activity ratios were due to leaching of shaley soils. Furthermore, they suggested that Ca-P-U complexes in fertilizer have lower solubility than oxidized forms of uranium in natural soils. The interpretation of ${ }^{234} \mathrm{U} /{ }^{238} \mathrm{U}$ activity ratios in river water have shown to be more complex due to in-stream scavenging processes between dissolved and particulate forms, whose affect on the activity ratio depend on season, $\mathrm{pH}$, and salinity (Plater et al., 1992; Rodriguez-Alvarez and Sanchez, 1999). Organic rich sediments appear to sequester uranium most efficiently and can be a potential source of high ${ }^{234} \mathrm{U} /{ }^{238} \mathrm{U}$ activity ratios (Porcelli et al., 1997).

\section{Additional Isotopes}

Other isotope tracers have been used as source and process tracers in surface water systems, but are beyond the scope of this investigation. The reader is encouraged to read Ingri et al. (1997) and Robinson and Botrell (1997) for interesting uses of sulfur isotopes 
in river catchments, and their relation to acid rain deposition. Also a good introduction to boron isotopes as water tracers can be found in Bassett et al. (1995) and Komor (1997), although the conclusion of this report is that boron is subjected to absorption by clay minerals for which there is a large isotopic fractionation ( 40 per mil).

\section{Multi-isotope Tracer Approaches in Surface Water}

A limited number of studies of river water have used a multiple isotope measurement approach in attempt to delineate the complex nature of various sources and processes of dissolved inorganic constituents (e.g. Hitchon and Krouse, 1972; Longinelli and Edmond, 1983; Aravena and Suzuki, 1990; Buhl, et al., 1991; Yang et al., 1996; Karim and Veizer, 2000). This brief discussion is included since the concept is generally the same as the one applied in this present report. Studies of this nature are more common in groundwater, mostly because the uncertainties in sources and replenishment rates of groundwater supplies can be greatly reduced by multiple independent measures of some parameters, such as groundwater age (e.g. Ivanovich et al., 1991). Likewise, multiple isotope measures of river water may provide a more integrated picture of physio-and biochemical processes governing natural and anthropogenic water quality. An integrated view can provide a model framework in which to predict or modify water quality at a point of use, or mitigate potential future negative impacts from current river basin conditions.

Nevertheless, these multiple isotope studies are in general revealing. For example, Hitchon and Krouse (1972) investigated $\delta^{18} \mathrm{O}, \delta \mathrm{D}, \delta^{13} \mathrm{C}_{\mathrm{DIC}}$, and $\delta^{34} \mathrm{~S}_{\mathrm{SO} 4}$ in Canadian rivers and found strong continental effects and subsequent evaporation controlling the significant $\delta \mathrm{D}$ and $\delta^{18} \mathrm{O}$ variations. They found that the $\delta^{13} \mathrm{C}$ mostly had limited 
atmospheric exchange and was generated by rock dissolution and biogenic respiration. The $\delta^{34} \mathrm{~S}$ reflect three different rock sources of various age and environmental deposition. In contrast, Longinelli and Edmond (1983) for the equatorial Amazon River, found very little continental effect in the river water due to strong recirculation of water vapor from the forest canopy, which buffered the isotopic composition of precipitation. Because of the dense tropical forests, the $\delta^{13} \mathrm{C}_{\mathrm{DIC}}$ was mostly control by respiration, showing little rock dissolution control or atmospheric exchange. Also, the $\delta^{34} \mathrm{~S}_{\mathrm{SO} 4}$ was uniform in this basin due to one source rock area rich in gypsum. However, the $\delta^{18} \mathrm{O}_{\mathrm{SO} 4}$ decreased downstream presumably due to reduction-mediated exchange with dissolved oxygen. Karim and Veizer (2000) noted in $\delta^{34} \mathrm{~S}_{\mathrm{SO} 4}$ and $\delta^{18} \mathrm{O}_{\mathrm{SO} 4}$ values for the Indus River that $\mathrm{SO}_{4}$ originated as oxidation of sulfide minerals.

In another study in Chile, Aravena and Suzuki (1990) found that $\delta^{18} \mathrm{O}$ was largely controlled by groundwater discharge and that the $\delta^{13} \mathrm{C}_{\mathrm{DIC}}$ and ${ }^{14} \mathrm{C}_{\mathrm{DIC}}$ were control mostly by subsurface volcanic emissions of $\mathrm{CO}_{2}$ in this highly volcanic terrain. Yang et al. (1996) for the St. Lawrence River found that the Great Lakes buffered isotopic abundances of water, $\mathrm{SO}_{4}, \mathrm{Sr}$, and DIC, even though upstream tributaries showed large variations. The $\delta^{13} \mathrm{C}_{\mathrm{DIC}}$ was in near isotopic equilibrium with atmospheric $\mathrm{CO}_{2}$. Lastly, Buhl et al. (1991) observed in the Rhine River similar $\delta^{18} \mathrm{O}$ and $\delta^{13} \mathrm{C}$ variations for northern hemisphere rivers, but that the ${ }^{87} \mathrm{Sr} /{ }^{86} \mathrm{Sr}$ ratios were mostly controlled by discharge of salt mine waste and industrial effluent, rather than from primary rock sources within tributaries having distinct ${ }^{87} \mathrm{Sr}{ }^{86} \mathrm{Sr}$ ratios. 


\section{Tracing Dissolved Organic Matter in Surface Water}

\section{Introduction}

Interest in understanding the sources and character of natural organic matter spans nearly 200 years, with concerted efforts to isolate and chemically characterize its nature beginning in the early 1900's (see Stevenson, 1985 for history of soil organic matter, and Thurman, 1985 and Malcolm, 1985 for history of aquatic humic material). The amount of organic carbon in rivers became a major concern later when industrial effluents and raw sewage that discharged into rivers and lakes contributed to high BOD and oxygen sag. More recent water quality interest in dissolved organic matter is associated with drinking water chlorination and the formation potential of disinfection by-products (e.g. Rook, 1977, Larson and Webber, 1994, Singer, 1999).

Parallel research apparently divorced of drinking water quality interests has existed in ecosystem and climate studies. Here much of the research has focused on the role of aquatic organic matter as a base nutrient in food chains (e.g. Munster and Chrost, 1990), global fluxes with respect to the carbon cycle (see Schlesinger, 1994), and its rate of turnover in terrestrial ecosystems (e.g. Hedges et al., 1986). These research areas in many respects pursue similar questions as in the water quality field regarding source and character of organic matter, but have no traditional overlap.

One necessary digression at this point requires review of terminology used for organic matter. In the natural sciences, aquatic organic matter is usually separated into three fractions. These include 1) dissolved organic matter (DOC), which is organic matter that passes through a $0.45 \mu \mathrm{m}$ filter, 2) particulate organic matter (POC), which is retained by the $0.45 \mu \mathrm{m}$ filter and has been referred to also as suspended organic matter, and 3) total 
organic matter (TOC), which is the sum of the DOC and POC. In the drinking water quality field there has been traditional use of the term TOC for measurements of surface water filtered at $0.45 \mu \mathrm{m}$. However, technically the measurement is DOC, but since many rivers and streams comprise mostly $<0.45 \mu \mathrm{m}$ organic material, the terminology has been freely interchanged. The reader is referred to Thurman (1985) for further discussion. This report will use, whenever possible, DOC.

\section{DOC Concentrations}

Thurman (1985) summarized the DOC concentration in world rivers, showing the highest concentrations were in wetlands and swamps (avg. $25 \mathrm{mg} / \mathrm{L}$ ), the lowest in arctic, alpine, and arid regions (avg. 2-3 mg/L), and temperate to tropical climates were in between (avg. 3-7 mg/L). Climate is one of the most important factors controlling DOC concentration in rivers (Thurman, 1985). Annual precipitation and temperature independently control terrestrial climate and vegetation in a watershed. Their correlation to net primary productivity (NPP) of vegetation has long been established (see e.g. Schlesinger, 1996). Areas of high precipitation, temperatures, and NPP (i.e. tropics) typically have extensively weathered soils somewhat poor in organic matter, and their associated rivers typically have high DOC. In contrast, regions with lower NPP (e.g. prairies) typically have less weathered soil with a high organic carbon sequestering capacity. Consequently, rivers in more arid climates tend to have lower DOC. High dissolved solids are typical for river waters in semi-arid to arid regions, whereas low dissolved solids are common in temperate woodland, alpine, and tropical rivers. Tropical soils are typically devoid of divalent cations, and hence humic substances comprising 
DOC are more readily soluble (see e.g. Hayes and Swift, 1978). This also is consistent with observations of Aiken and Malcolm (1987), who showed that DOC concentrations and the molecular weights of their humic substances (see below) were inversely proportional to the dissolved solid concentration of the surface waters. They similarly concluded that more weathered soils have fewer divalent cations and produce dissolved humic substances with higher solubilities and higher molecular weights.

Within river systems different vegetation types and microclimates can control DOC concentrations. For example, in the southeastern US lowland areas comprising wetland settings produce significantly higher DOC than upland forested areas (e.g. Mulholland and Kuenzler, 1979). Wetlands typically have high carbon fixation rates and are known to discharge water with high DOC concentrations (e.g. Mann and Wetzel, 1995). In the Missouri River, annual precipitation is twice as high in the lower river area than in the upper watershed, and similar DOC differences are expected (see below).

Podzolization of soil at depth has been shown to increase sequestration of DOC leached from shallower zones, and has been shown to affect stream DOC concentration (McDowell and Wood, 1984). Soil formation in different geologic rock types can have a significant effect of organic carbon sorption and DOC concentrations in adjacent streams, somewhat independent of climate (Nelson et al., 1993). More recent work has shown that soil mineralogy also plays an important role in cycling rates of soil organic matter (Torn, et al., 1997).

During storm flow, DOC concentration in a river typically rises. Studies attribute this rise to flushing of DOC-rich soil water and leaching of leaf litter from runoff and 
throughflow of shallow groundwater through the soil (e.g. Brinson, 1976; Thurman, 1985; Fiebig et al., 1990).

Lastly, storage of river water in large reservoirs, effluent from agricultural irrigation, and treatment through artificial wetlands can all have significant effects on the DOC concentration, including increased POC from algae and higher disinfection byproduct formation (e.g. Amy et al., 1990; Parks and Baker, 1997)

\section{DOC Characterization}

Aside from bulk concentration measurements, a rich and diverse history of DOC characterization exists in the open literature. Much of this previous work is outside the scope of this report, but a brief summary is provided. Probably the most relevant feature of DOC characterization to this report is the distinction between allochthonous and autochthonous sources (see Thurman, 1985). Allochthonous DOC is derived from plant and soil sources, or outside the aquatic environment, whereas autochthonous DOC is generated within the water column. For example, autotrophs, such as algae, would be the most common autochthonous source of POC and DOC, whose amount varies depending on the aquatic system and season. Most river environments are dominated by allochthonous DOC because of adjacent soils and vegetation. However, where natural or man-made lakes and reservoirs are present, autotrophic contribution to the DOC pool can increase, particularly where nutrient levels are high. Typical algal production can vary in lakes depending on latitude, climate, lake depths, clarity and nutrient levels. For example, mid-latitude lakes $\left(39-55^{\circ} \mathrm{N}\right)$ have photosynthetic fixation rates up to $2 \mathrm{gC} / \mathrm{m}^{2}$-day in midsummer, whereas they will be nearly 10 times lower in winter, while equatorial lakes 
show little seasonal variation but have high photosynthetic fixation rates (e.g. $5 \mathrm{gC} / \mathrm{m}^{2}$ day; Tilzer, 1987). The distribution of allochthonous and autochthonous sources of DOC in rivers will in general be dictated by the amount of algal productivity within the flowing water, the number and character of surface impoundments contributing to the flow, latitude, and the season.

Besides allochthonous and autochthonous forms of DOC, its character can also be delineated based on compound identification, chemical function, acidity, and solubility. The most rigorous attempts to identify chemical compounds have resulted in identification of only $10-20 \%$ of the DOC (e.g. Ding et al., 1996). In natural waters identifiable compounds typically are mono- and polysaccharides, amino acids, pigments such as chlorophyll $a$, and short-chained carboxylic acids (Lytle and Perdue, 1981; Sweet and Perdue, 1982; Thurman, 1985; Leenheer, 1994). The remaining is large molecular weight, non-polymeric phenolic compounds with molecular weight between 500-1000 Daltons that are generally referred to as humic substances. These are usually recalcitrant plant and bacterial residues, and can be separated and isolated based on absorption and solubility. In soil science, base extraction of soils produces humic substances, and following centrifugation and strong acid in the decanted solution always forms humic acid precipitate, with a lesser amount of fulvic acid remaining in solution (Stevenson, 1985). Humic acids have low solubility, and therefore their common association with soils, whereas fulvic acids are more soluble and are more common in rivers (e.g. Malcolm, 1985).

Many spectroscopy methods are available to characterized DOC by functional groups. For many years researchers struggled with isolation and purification of DOC. 
Unfortunately, loss due to either sorptive media or desalting by ion exchange always resulted in preferential loss of specific compound classes. Nevertheless, early work did much to identify many functional classes of DOC (e.g. carboxylic acids, hydroxyls, ketones). The development and use of non-ionic resins in the late 1970's did much to advance the field of isolation and characterization, and resulted a general operational class of organic isolates (Thurman and Malcolm, 1981; Aiken et al., 1994). XAD-8 and $\mathrm{XAD}-4$ are commonly employed today to isolate and purify DOC into humic and hydrophilic substances, respectively. Humic substances extracted from water can be separated into humic and fulvic acid upon acidification. The humic substances tend to be aromatic rich, with aliphatic linkages (Malcolm, 1985). Hydrophilic substances tend to be more carbohydrate rich, and have a higher density of oxidized functional groups (Aiken et al., 1994), hence their higher solubility. XAD-8 and XAD-4 do not isolate all the DOC in a sample. Higher conductivity water tends to have poor yields on the resins. Recent advancements added to these isolation techniques have achieved $\sim 100 \%$ recoveries of DOC into purified isolates (Leenheer et al. 2000). In particular, the unrecoverable fraction of DOC appears to be microbial cell-wall residues.

\section{Isotopic Studies of Dissolved Organic Matter}

Isotopic studies of DOC have been surprisingly limited. Most isotopic data for aquatic organic matter has been conducted on POC, usually in ecological and climat-related studies. For example, previous observation of $\delta^{13} \mathrm{C}$ values measured on aquatic organic matter in rivers showed annual $\delta^{13} \mathrm{C}$ variations (up to 6.0 per mil) in POC from Sanaga River water in Cameroon (Bird et al., 1998). The $\delta^{13} \mathrm{C}$ was enriched during high flows, 
and depleted during low flows. These workers related the variation to different vegetation types in the watershed, namely plants with $\mathrm{C} 4$ metabolic pathways in grass-dominated savannah contributed higher $\delta^{13} \mathrm{C}$ during high flow, and $\mathrm{C} 3$ vegetation growing adjacent to the river bank dominated during low flow. Goñi et al. (1998) proposed a similar process contributing to sedimentary organic matter measured for $\delta^{13} \mathrm{C}$ on specific isolates in the Mississippi River delta. Based on lignin analysis and ratios of phenolic compounds, they showed that a small portion of sedimentary organic matter was terrigenous in origin and that its $\delta^{13} \mathrm{C}$ variation was due to a mixture of soil organic matter from C4 and C3 plant material. In contrast, Barth et al. (1998) concluded that $\delta^{13} \mathrm{C}$ variations ( $\sim 6.0$ per mil) of POC in the upper St. Lawrence river was primarily due to photosynthetic production. This was most prevalent in near-shore or embayment areas of the river. The $\delta^{13} \mathrm{C}$ of $\mathrm{POC}$ in the main channel varied to a lesser degree, but they concluded that the bulk of the POC was derived from photosynthesis in the Great Lakes. Similar variations in $\delta^{13} \mathrm{C}$ of POC have been noted in the Great Lakes (Hodell and Schelske, 1998).

Other isotopic works have been conducted in ocean settings for source indication (Williams et al., 1992), and in the Amazon Basin for biogeochemical cycling (Hedges et al., 1986; Quay et al., 1992). Other relevant work are isotopic studies of soil organic matter to determine natural cycling rates (Trumbore, 1993; Harrison et al., 1993, Torn et al., 1997), turnover of carbon pools using natural $\delta^{13} \mathrm{C}$ variations (Heidmann and Scharpenseel, 1992; Wedin et al., 1995), and for processes that control stable isotopic changes during soil aging (Natelhoffer and Fry, 1988). 
The carbon isotopic composition of bulk DOC in surface water has been measured in at least one study of a small watershed, where $\delta^{13} \mathrm{C}$ and ${ }^{14} \mathrm{C}$ measurements of surface water DOC were compared to groundwater and soil water DOC values (Schiff et al., 1990; Schiff et al., 1997): In a more recent example, isotopic abundances of humic substances in soil and water were conducted to elucidate effects of land use change on soil organic matter turnover (Kalbitz et al., 2000). Isotopic analysis of groundwater DOC has been developed specifically as an age-dating tool (Wassenaar et al., 1990; Artinger et al., 1996). In these studies humic substances were isolated specifically for the measurement.

\section{$\underline{\text { Study Areas }}$}

\section{Missouri River System}

The Missouri River above St. Louis is one of the great rivers of the world in terms of its length $(2533 \mathrm{mi})$ and drainage area $\left(529,400 \mathrm{mi}^{2}\right)$, but not in terms of its average discharge, which is only about $78,570 \mathrm{cfs}$ (van der Leeden, 1975; Fig. 2). The river originates at the continental divide in Montana and joins the Mississippi River about 15 miles above St. Louis, Missouri, and en route drains much of the Great Plains of the USA and southernmost Canada. Along its length the character of the river changes markedly, from a fast clearwater stream fed by alpine snowmelt, through 5 major impoundments in the midwestern plains, and ultimately to a large meandering channel in the State of Missouri, where the average gradient is only 0.85 feet per mile. Annual precipitation in the prairie-dominated midwestern plains (avg. $\sim 20 \mathrm{in} / \mathrm{yr}$ ) is much lower than in the woodland-dominated lower river area of Missouri (avg. $\sim 40 \mathrm{in} / \mathrm{yr}$ ). 


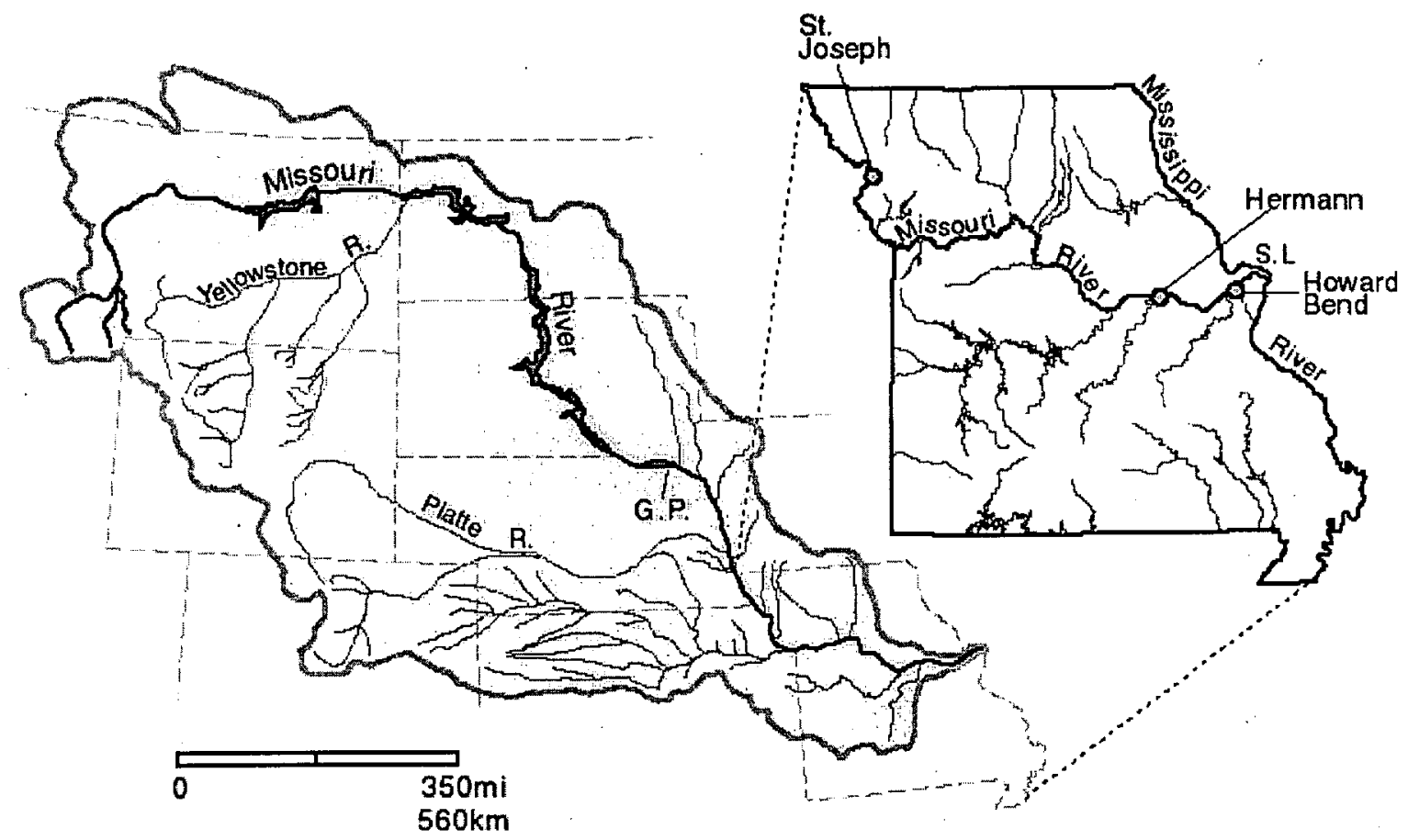

Figure 2. Missouri River Basin and sampling points in Missouri for this study. Note the Missouri River is largely dammed in the upper portion of the watershed, while the lower watershed is mostly navigable waters.

Several aspects of Missouri River water are distinctive. Although the river has a typical Ca-Mg bicarbonate chemistry, an unusual aspect is that the dissolved solid content decreases downstream across the state of Missouri (Homyk and Jeffery, 1967). The river is famous for its high sediment load, yet this load may have been even higher before cultural development of the watershed. Concentrations of agrochemicals are a growing concern for this and many other midwestern rivers (e.g., Thurman et al., 1991).

Streamflow variations of the Missouri River are also unusually large for a river of its size. During the last 40 years, daily mean streamflow at the Hermann, Missouri gauging station has varied from $6210 \mathrm{cfs}$ (Dec. 23,1963 ) to $739,000 \mathrm{cfs}$ during the July 31,1993 flood peak, representing more than a hundredfold variation (Hauck et al, 1997). Flows 
outside these extremes are estimated if the historical period is extended, for example, to include the 1844 flood.

The modern appearance of the Missouri River belies its natural, predevelopment character. Historically the river was braided with an anastomosing channel that included many small islands and bars (e.g., Izenberg, 1996; Patrick, 1998). Wildlife was abundant but the numerous snags, sand bars and caving banks presented severe hazards to navigation, even for small vessels as lucidly described by Lewis and Clark. Catastrophic losses during the steamboat era led to snag removal and other navigational improvements, and by the 1930 's, the river was engineered to a single channel by dredging and by construction of levees, wing dams, and bank stabilization works. Across the state of Missouri, the transformation of the natural river to its nearly invariant channel with a 9 foot minimum depth was effected by an $8 \%$ reduction in total length, a $50 \%$ reduction in the water surface area, a $98 \%$ reduction in island area, and the removal of nearly 20,000 snags (Funk and Robinson, 1974).

The City of St. Louis, Department of Public Utilities, operates and maintains two surface water treatment plants that combined produce 140 million gallons of drinking water per day for the City of St. Louis. One plant is located at the Howard Bend Station (Fig. 2) along the lower end of the Missouri River. The second plant is the Chain of Rocks Station located on the west-bank of the Mississippi River just below the confluence of the Missouri and Mississippi Rivers. However, based on historical water quality data, the Chain of Rocks plant draws $100 \%$ Missouri River water, since the rivers have not mixed appreciably at the plant's intake point (Dave Visintainer, personal communication). This has been verified by comparative $\delta^{18} \mathrm{O}$ measurements between the two rivers collected at 
the same time (Robert Criss, personal communication). The plants use standard practices of settling, coagulation, sand filtration, and chlorination for water treatment. The Public Works Department has historically been concerned with high suspended loads in the Missouri River, which increase settling times, but more recently by the potential of microbial contamination and disinfection by-product production during chlorination. They were recently a participant in US EPA's 18 month Information Collection Ruling.

\section{California Rivers}

California provides a unique setting in which to study rivers. The area experiences Mediterranean climate with long dry summers followed by a shorter, but intense winter precipitation. The physiography is diverse with coastal mountains reaching $\sim 3500$ feet lying adjacent to one of the world's largest closed basins know as the Central Valley. The valley rises steeply to the east where the Sierra Nevada Mountains reach elevations in excess of 14,000 feet. Precipitation originates mostly from Pacific Ocean tropical and arctic air convergence, producing annual precipitation ranging from $<6 \mathrm{in} / \mathrm{yr}$ in California's southeastern deserts to $>200 \mathrm{in} / \mathrm{yr}$ in the coastal mountains of northeastern California.

The Sacramento and San Joaquin Rivers are the two main river systems draining the interior of California with combined flows averaging $\sim 29$ million acre-ft per year (Fig. 3; $\sim 40,000 \mathrm{cfs})$. Major water works that have dramatically changed the natural character if these rivers include the Central Valley Project and the State Water Project, whose combined annual reservoir storage is 14.4 million acre-ft. The Central Valley Project is a federal program created in the 1930 s to supply San Joaquin Valley farmers with an 
irrigation supply to offset growing deflation of regional groundwater from pumping. This transformed California's Central Valley into a major world supplier of fresh produce and cotton worth billions of dollars annually today. Long-term tradeoffs for this large-scale surface water diversion include reduced fish populations in the Sacramento-San Joaquin Delta because of loss in spawning and feeding habitat, and increased salt accumulation and water-logging beneath agricultural fields. Through time, fields were lined with open tile pipes to promote drainage, and salt-laden water was diverted down the man-made Delta-Mendota Canal. Approximately 15 years ago, it was discovered that many of these salt-laden waters were hazardly-enriched in selenium and dramatically affected reproduction in migratory bird populations in restored wetlands (see Harris, 1991 for review). Today, selenium and salt discharge is minimized by regulated drainage and retirement of agricultural land having the greatest impact.

The State Water Project was constructed in the $1950-1970$ s to specifically divert water to a rapidly growing population in southern California. The project principally consists of Lake Oroville, which dams and stores 3.5 million acre-ft of Feather River water in northern California, and transfers it south via the California Aqueduct. The aqueduct is a concrete-lined channel that lifts this water a total of $\sim 3000$ feet and delivers it to a large area across southern California. The pumping of water into the aqueduct occurs in the southwestern portion of the Delta, and the source of the water pumped is a mixture of Sacramento and San Joaquin River water. Another diversion of Delta water follows the South Bay Aqueduct, which delivers surface water to San Francisco Bay residents in the southeastern and southern Bay regions. 
Water agencies utilizing Delta water for drinking purposes are the Contra Costa Water District, the Metropolitan Water District of Southern California, and several other agencies in the Bay area. These agencies are concerned over the potential for increasing levels of TOC and pathogens in Delta water and its affect on treatability. The current CalFed process funded to "fix" the Delta by bring agricultural, ecological, and urban demands in balance are faced with tough scrutiny from these drinking water interest, since some mitigation strategies may easily promote TOC increase. The 35 million people today in California are faced with a $>50 \%$ population increase in the next 25 years, and the ultimate decisions regarding the Delta will affect water availability for a large percentage of these people.

This report shows several isotopic reconnaissance studies in California rivers, with some limited detailed work in the lower San Joaquin River. Figure 3 shows sampling sites visited once or on a repeated basis during the course of this study, but details of each river system shown are beyond the necessary scope of this particular report. However, below is reported some more detail of the San Joaquin River for further reference later. 


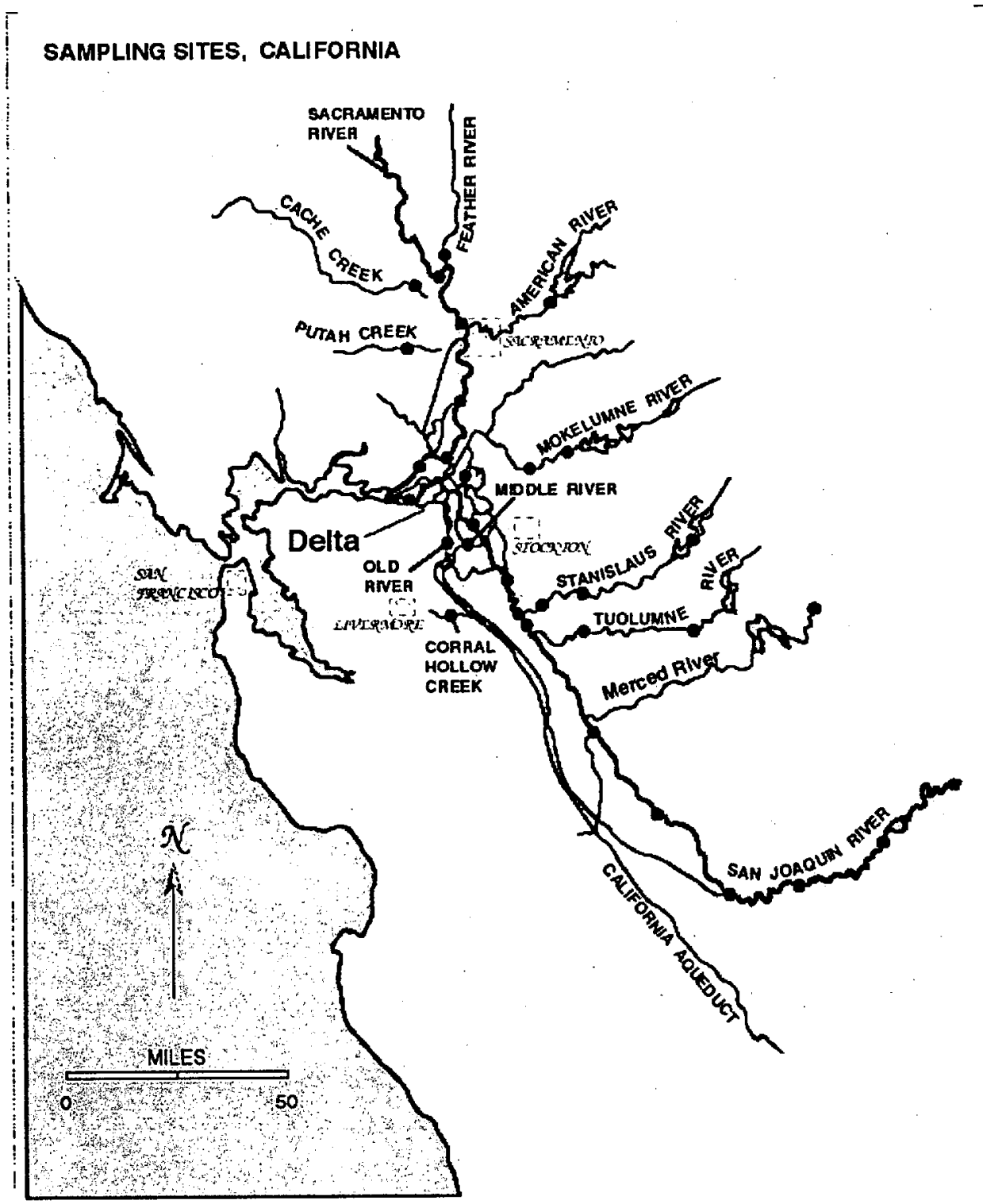

Figure 3. California's diverse physiography gives rise to several large river systems draining the interior of the state, and they all meet at the Sacramento-San Joaquin Delta. Major diversion projects over the years have dramatically affected the ecological conditions of the rivers and their drinking water quality.

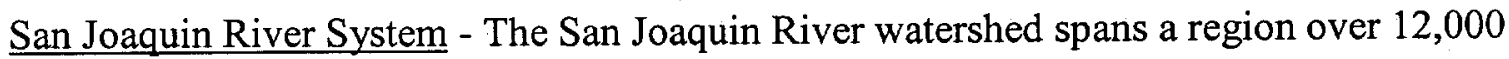
$\mathrm{mi}^{2}\left(31,000 \mathrm{~km}^{2}\right)$. The upper watershed is a temperate alpine area of the Sierra Nevada Mountains (avg precipitation is $43 \mathrm{in} / \mathrm{yr}$ ), with elevations exceeding $10,000 \mathrm{ft}$, while the mid- to lower reaches are semi-arid (avg. rain is $12 \mathrm{in} / \mathrm{yr}$ ) dominated by intense agricultural irrigation (Fig. 4). The river terminates in the Sacramento-San Joaquin Delta. 
Water quality has deteriorated in the river water over time, mostly due to high salt and organic loads in runoff from irrigated land, and loss of natural wetland habitat.

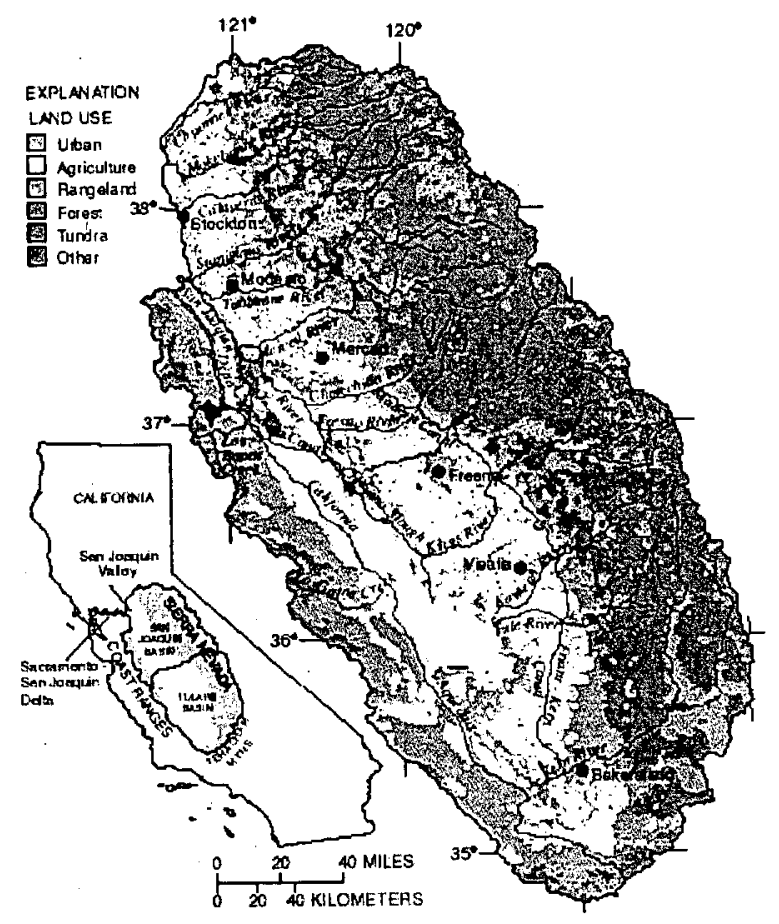

Figure 4. The San Joaquin River watershed encompasses half the San Joaquin Valley and a significant portion of the southern Sierra Nevada drainages. The alpine, irrigated agriculture, and deltaic environments all within the watershed make the river basin geochemically diverse. Figure is from Dubrovsky et al. (1998).

Mean annual discharge in the San Joaquin River is about $4600 \mathrm{cfs}$, with flood stage reaching $79,000 \mathrm{cfs}$. The San Joaquin is a highly manipulated waterway, with hydroelectric diversion in the upper watershed with significant storage in reservoirs (1.2 million acre-ft capacity). In addition, the entire discharge of the river below Fresno California is diverted for agricultural irrigation. During the summer, by the time the river flows along its normal course on the west-side of the San Joaquin Valley, the flow nearly disappears. In order to maintain mandated flows into the Delta, a combination of diverted water from the Delta and agricultural return flows are added to the river channel. This 
changes the water quality of the river. Soils and shallow groundwater in these areas are known for their saltiness and highly enriched selenium content (e.g. Deverel and Gallanthine, 1989), which dramatically increases dissolved salt loads and geochemical character of the river.

\section{Method and Materials}

This study utilized daily water quality analyses generated by the City of St. Louis Public Works, Howard Bend Plant on the Missouri River. They generate daily values for electrical conductivity, $\mathrm{pH}$, temperature, and alkalinity all by standard EPA methods. They also collect daily stage measurements of river height. These stage measurements are converted to discharge by comparing them to discharge records at the US Geological Survey gauging station at Hermann, Missouri, approximately 60 miles upstream. The discharge at Hermann is highly correlative with Howard Bend stage measurements $\left(\mathrm{R}^{2}=\right.$ 0.93). Additional data was collected by the US Geological Survey stream gauging stations throughout the watershed and was available over the web.

Daily to bi-weekly samples for $\delta^{18} \mathrm{O}$ measurements were collected by Howard Bend personnel and Robert Criss at Washington University of St. Louis. Most $\delta^{18} \mathrm{O}$ data was generated at Washington University using standard $\mathrm{CO}_{2}$ equilibration techniques followed by isotope ratio mass spectrometry (Epstein and Mayeda, 1953). The $\delta^{18} \mathrm{O}$ values of water collected for DOC isotope analyses were measured at LLNL by the same method. Isotopic abundances are reported as a ratio to a known standard and converted by the $\delta$ equation defined earlier. 
Samples for dissolved anions were collected in Nalgene plastic bottles, and those for nitrate were preserved with mercuric-chloride. Measurements were analyzed on a Dionex BioLC Ion Chromatography System by standard methods. Sample bottles for trace metals were commercially-cleaned I-Chem bottles that were leached with $1 \%$ trace metal grade Seastar nitric acid for two weeks, then leached with Milli-Q water for one week. An aliquot of each sample was filtered through a $0.45 \mu \mathrm{m}$ Gelman filter in a clean lab. These samples were kept refrigerated and preserved with trace metal grade Seastar nitric acid. Trace metals were analyzed on a Finnigan Mat magnetic sector field ICP-MS housed at Washington University, St. Louis. The ${ }^{234} \mathrm{U} /{ }^{238} \mathrm{U}$ ratios were also determined on this instrument using isotope dilution methods since it has a high resolution, multi-collection capability (e.g. Hinrichs and Schnetger, 1999).

Samples for ${ }^{13} \mathrm{C}$ and ${ }^{14} \mathrm{C}$ measurements on DIC were collected in a $125 \mathrm{ml}$ glass bottle with a Teflon-lined rubber septa cap to prevent exchange with atmospheric $\mathrm{CO}_{2}$. Approximately 4 drops of a saturated $\mathrm{HgCl}_{2}$ solution were added as a preservative and samples were kept refrigerated until analysis. The inorganic carbon was acid stripped under high vacuum and purged with an ultra pure carrier gas (Davisson and Velsko, 1994) similar to methods of $\mathrm{McNichol}$ et al. (1994). The liberated $\mathrm{CO}_{2}$ was then reduced to graphite on a separate vacuum line using a cobalt catalyst and hydrogen gas at a $570^{\circ} \mathrm{C}$ reaction temperature (Vogel et al., 1987). All ${ }^{14} \mathrm{C}$ concentrations were determined on the accelerator mass spectrometer at LLNL. The $\delta^{13} \mathrm{C}$ results are reported in the same format $\delta^{18} \mathrm{O}$, but corrected against NBS PDB standard. The ${ }^{14} \mathrm{C}$ is reported as a percent of modern carbon (pmc) relative to a 1950 atmospheric $\mathrm{CO}_{2}{ }^{14} \mathrm{C}$ standard (Stuiver and Polach, 1977). Method precision averaged \pm 0.1 per mil for $\delta^{13} \mathrm{C}$, and \pm 1 pmc for ${ }^{14} \mathrm{C}$. 
Samples for ${ }^{36} \mathrm{Cl} / \mathrm{Cl}$ ratios were collected in commercially-cleaned I-Chem bottles. The ${ }^{36} \mathrm{Cl}$ was extracted by precipitating a quantitative yield of $\mathrm{Cl}$ from the water by adding $\mathrm{AgNO}_{3}$ and precipitating a $\mathrm{AgCl}_{2}$ solid (Bentley et al., 1986). The $\mathrm{AgCl}_{2}$ was then dissolved in $\mathrm{NH}_{4} \mathrm{OH}$ to precipitate out sulfates. The aqueous solution was filtered and $\mathrm{AgCl}_{2}$ was reprecipitated by acidification. The precipitate was then washed, dried-down, and packed into an aluminum target. The ${ }^{36} \mathrm{Cl}$ was analyzed by accelerator mass spectrometry at LLNL and reported as a ratio of ${ }^{36} \mathrm{Cl}$ to total $\mathrm{Cl}$ measured in the water (Elmore et al., 1979).

The methyl-tert-butylether was measured on a few river samples collected in California. A method for a 15 part per trillion detection limit was developed to quantify concentrations in surface waters (Koester et al., 1998). A $25 \mathrm{ml}$ sample collected in ultraclean $40 \mathrm{ml}$ VOA vials (I-Chem), were purged and trap by standard methods, and analyzed by GC/MS using an ion-selective mode.

Samples for ${ }^{13} \mathrm{C}$ and ${ }^{14} \mathrm{C}$ analysis on $\mathrm{DOC}$ and its humic fractions were collected in one liter pyrex bottles pre-combusted at $500^{\circ} \mathrm{C}$ for 3 hours. A few drops of concentrated mercuric-chloride were added in the field to poison any microbes potentially metabolizing the DOC. Samples were stored on ice in the dark. Samples for isotope analysis on total DOC were filtered at $1.0 \mu \mathrm{m}$ with pre-combusted glass fiber filters. Samples used for humic substance isolation were filtered at $0.45 \mu \mathrm{m}$ with a nylon filter cartridge (Gelman) pre-flushed with 2 liters of MilliQ/UV-Plus lab water having a DOC concentration $<0.1 \mathrm{mg} / \mathrm{L}$.

DOC measurements were made on a Shimadzu 5000A TOC analyzer by high temperature combustion to $\mathrm{CO}_{2}$ followed by $\mathrm{IR}$ detection and quantification. For isotopic 
analyses of bulk DOC, $500-1000 \mathrm{ml}$ of filtered water was rota-evaporated to $\sim 10 \mathrm{ml}$ and then acidified with ultrapure $6 \mathrm{~N} \mathrm{HCl}$ to remove inorganic carbon. The solution was freeze dried, and the powder was homogenized and stored in a glass vial inside a container of desiccant. The powder was weighed into a $6 \mathrm{~mm}$ Vicor tube, placed together in a $9 \mathrm{~mm}$ Vicor tube with $\mathrm{CuO}$, vacuum sealed, and combusted at $900^{\circ} \mathrm{C}$ for 3 hours. The $\mathrm{CO}_{2}$ was cryogenically purified on a vacuum line, split for $\delta^{13} \mathrm{C}$ determination by isotope ratio mass spectrometry, and the remainder was converted to graphite and analyzed for ${ }^{14} \mathrm{C}$ on an accelerator mass spectrometer at LLNL (see above). Method precision averaged \pm 0.2 per mil for $\delta^{13} \mathrm{C}$, and \pm 2 pmc for ${ }^{14} \mathrm{C}$.

DOC was fractionated into its humic substances using XAD-8 resin (Supelco DAX-8) packed in a $0.5 \mathrm{~cm}$ diameter $X 30 \mathrm{~cm}$ long glass column with teflon stopcocks, following the resin preparation and analytical methods of Thurman and Malcolm (1981). 1-2 liters were pumped over the XAD- 8 at $\leq 500 \mathrm{~m} 1 / \mathrm{hr}$ at $\mathrm{pH} 2.0$. The sorbed humic substances were eluted with $0.1 \mathrm{~N} \mathrm{NaOH}$. No attempt was made to extract residual $\mathrm{DOC}$ retained on the resin, noted by a weak brown staining after elution. Eluates were acidified to $\mathrm{pH}$ of 1.0 with concentrated ultra-pure $\mathrm{HCl}$ to separate humic acids from fulvic acids. Humic acid precipitation generally took 2 weeks to 1 month because of the low humic acid content. The humic acid was separated by centrifugation and both humic fractions were freezedried, combusted, and prepared by the same method as the bulk DOC. Samples of humic samples received from Jerry Leenheer at the US Geological Survey were prepared by the same method. 


\section{Results and Discussion on the Missouri River}

\section{$\underline{\text { Relationship Between Discharge and Electrical Conductivity }}$}

Discharge in the Missouri River has a seasonal cycle, with maximum annual flows occurring between March and May. Seasonal changes in river discharge cause a proportional change in the electrical conductivity (EC) from as low as $\sim 200 \mu \mathrm{S}$ during high flow to greater than $900 \mu \mathrm{S}$ during low flow (Fig. 5). Also, EC decreases downstream along the entire length of the Missouri River.

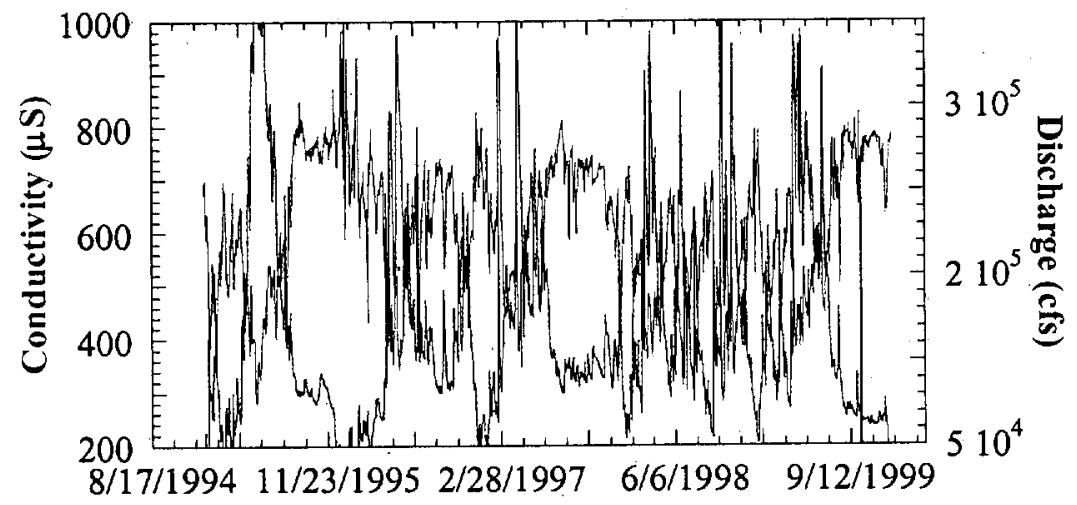

Figure 5. Electrical conductivity decreases when Missouri River discharge increases at the Howard Bend Plant. The large variation in conductivity is unusual for big rivers and suggests that baseflow has a distinct chemical source.

An important element to tracing the source of water quality requires some method of predicting water mass transport in a river system. In particular, a quantitative basis is needed for assessing the source of water in order to establish water quality origin. Much of this can be accomplished by comparing discharge for all major tributaries in the watershed. However, a simple water quality indicator or isotopic measurement at a downstream point is more attractive for its practicality. We can assume that many water quality parameters act conservatively during transport, and reflect processes that generate them in their source area. For example, the Missouri River EC varies with river discharge, suggesting that concentration is controlled by source. In order to assess the 
sources, the geographic areas contributing to EC need to be understood. In the most simplest and ideal cases, the EC would be controlled by one source. This is not necessarily an intuitive hypothesis given the geographic extent and complexity of the Missouri River system. However, increased flow is commonly associated with spring run-off, derived from snow melt and precipitation drainage and ideally represents a very low salt source or dilutant. As a demonstration, a simple test of a single source would be to compare EC with the inverse of river flow. Upon inspection, the EC and inverse discharge do not form a strong linear relationship $\left(r^{2}=0.42\right)$, indicating more that one source contributes to dissolved salt and a single source model for EC is not valid. Therefore, to gain insight into potential source areas the oxygen-18 data could provide good evidence, since it varies with geographic area.

\section{Oxygen-18 in the Missouri River}

$\delta^{18} \mathrm{O}$ values generated for Missouri River water collected at the Howard Bend Plant from 1995-1996 and after March, 1998 (El Nino) show a stronger inverse linear relationship with conductivity (Fig. 6). Recall that the $\delta^{18} \mathrm{O}$ value of precipitation and runoff varies geographically in continental environments, where values are more negative for areas of cooler temperature and also with increased distance from the ocean. The upper part of the Missouri River watershed includes cold alpine environments of Montana and Wyoming, whose annual snow packs provide much of the reservoir storage in the upper river. Snow melt water typically has low $\delta^{18} \mathrm{O}$ values $(-12$ to -19 per mil), and values have been reported for the upper Missouri between -15.8 and -17.6 per mil, the Yellowstone River at -17.7 per mil, the North Platte River between -15.4 and -16.1 
per mil, and the Missouri River at Fort Randall of $-13.8 \pm 0.7$ per mil (Coplen and Kendall, 2000).

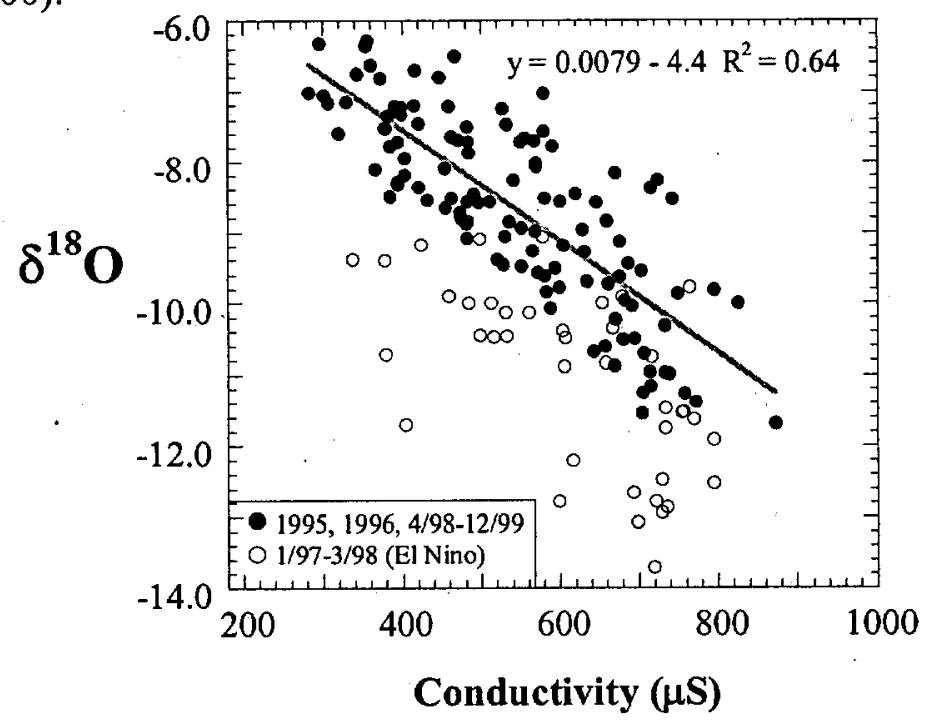

Figure 6. A good inverse correlation exists between conductivity of Missouri River water and its $\delta^{18} \mathrm{O}$ value. Lower $\delta^{18} \mathrm{O}$ values correspond to upper watershed sources, which have higher dissolved salt content. This trend was disrupted during the 1998 El Nino event.

Below the main stem reservoirs, the tributaries to the Missouri River drain lower elevation watersheds whose $\delta^{18} \mathrm{O}$ values will be less negative than that derived from Montana or Wyoming. For example, for the lower Platte River near the town of Louisville, the average $\delta^{18} \mathrm{O}$ value has been reported at $-9.1 \pm 1.5$ per mil (Coplen and Kendall, 2000). In the lower Missouri River, average $\delta^{18} \mathrm{O}$ values ranged from -6.1 to -6.8 per mil in smaller tributaries (Frederickson and Criss, 1999; Coplen and Kendall, 2000).

The $\delta^{18} \mathrm{O}$ value of the Missouri River at Howard Bend varies during the year from less than -13 per mil to greater than -7 per mil. This is consistent with discharge derived from either the upper watershed, lower watershed, or a combination of both. The exception to this is that during the winter, cold arctic storms produce regional precipitation (typically 
as snow) with low $\delta^{18} \mathrm{O}$ values (less than -10 per mil) in the lower watershed (see Fredrickson and Criss, 1999). Nevertheless, a simple two end-member approach (i.e. upstream versus downstream) is adequate for interpreting the $\delta^{18} \mathrm{O}$ observations at Howard Bend. Likewise, since the $\delta^{18} \mathrm{O}$ data show a good inverse correlation with EC, a simple two end-member approach also explains the source of dissolved salts in the Missouri River.

From Figure 6 it is logical to suggest that EC may be primarily controlled on average by two different salt sources. This may be a more plausible case for the simple reason that the Missouri River is characterized by an upstream component that has a semi-arid to temperate climate, and a downstream component that is temperate to humid. Mean daily discharge nearly doubles between St. Joseph in northwest Missouri and Howard Bend in southeastern Missouri.

\section{Geographic Separation of Discharge and Water Quality}

An alternate test on a two end-member source entails segregating the water quality data in terms of mass discharge. For example, we can separate the discharge measured at Howard Bend into an upstream and downstream component by recognizing

$$
X_{H e r}=\frac{D_{H e r}-D_{S J}}{D_{H e r}}
$$

where $D_{S J}$ is the measured discharge at an upstream point, $D_{H e r}$ is the measured discharge downstream at Hermann, MO, and $X_{H e r}$ is the fractional amount of discharge contributed between those two points. If a simple two end-member model for water quality is valid, 
then a comparison between a water quality parameter and the fraction of discharge $(X)$ from either upstream or downstream should result in a linearized relationship.

The fraction of downstream discharge $\left(X_{H e r}\right)$ was calculated from daily mean flows at St. Josephs and Hermann from 1995-1999. The daily mean discharge values measured at Hermann were offset four days in order to appropriately pair them to the St. Josephs data, since discharge has approximately a four day travel between these two locations (Criss et al., 2001). Calculated fractions of downstream flow are plotted against $\mathrm{EC}$ and $\delta^{18} \mathrm{O}$ in Figures $7 \mathrm{a}$ and $7 \mathrm{~b}$. The correlation between daily EC measurements and the fraction of downstream flow is linear $\left(\mathrm{R}^{2}=0.62\right)$. The relationship between the fraction of flow and $\delta^{18} \mathrm{O}$ is not as well constrained. This is likely due to complicating factors such as anomalous $\delta^{18} \mathrm{O}$ storm events (e.g. wintertime) that locally produce large discharge events either upstream or downstream. Nevertheless, the variation in EC appears to be strongly driven by the amount of upstream flow. The linear extrapolation through the data suggest that an end-member EC $\left(X_{H e r}=0\right)$ is $838 \mu \mathrm{S}$, whereas a downstream source $\left(X_{H e r}\right.$ $=1$ ) is $219 \mu \mathrm{S}$. Monthly average EC and discharge values improve the linear correlation $\left(\mathrm{R}^{2}=0.82\right)$, which can facilitate reliable salt load calculations (Criss et al., 2001). The daily and monthly EC values are far better constrained by separating discharge into geographically controlled flow components rather than simple comparisons with discharge at a single point.

Monthly average concentrations of water quality parameters collected at Howard Bend also show linear correlation with the fraction of downstream flow (Figs. 8abc). These include cations of $\mathrm{Ca}, \mathrm{Mg}$, and $\mathrm{Na}\left(\mathrm{R}=0.70,0.65,0.89\right.$ respectively), anions of $\mathrm{HCO}_{3}$, $\mathrm{SO}_{4}$, and $\mathrm{F}(\mathrm{R}=0.67,0.87,0.84$ respectively $)$, and DOC $\left(\mathrm{R}^{2}=0.63\right)$. Other constituents 


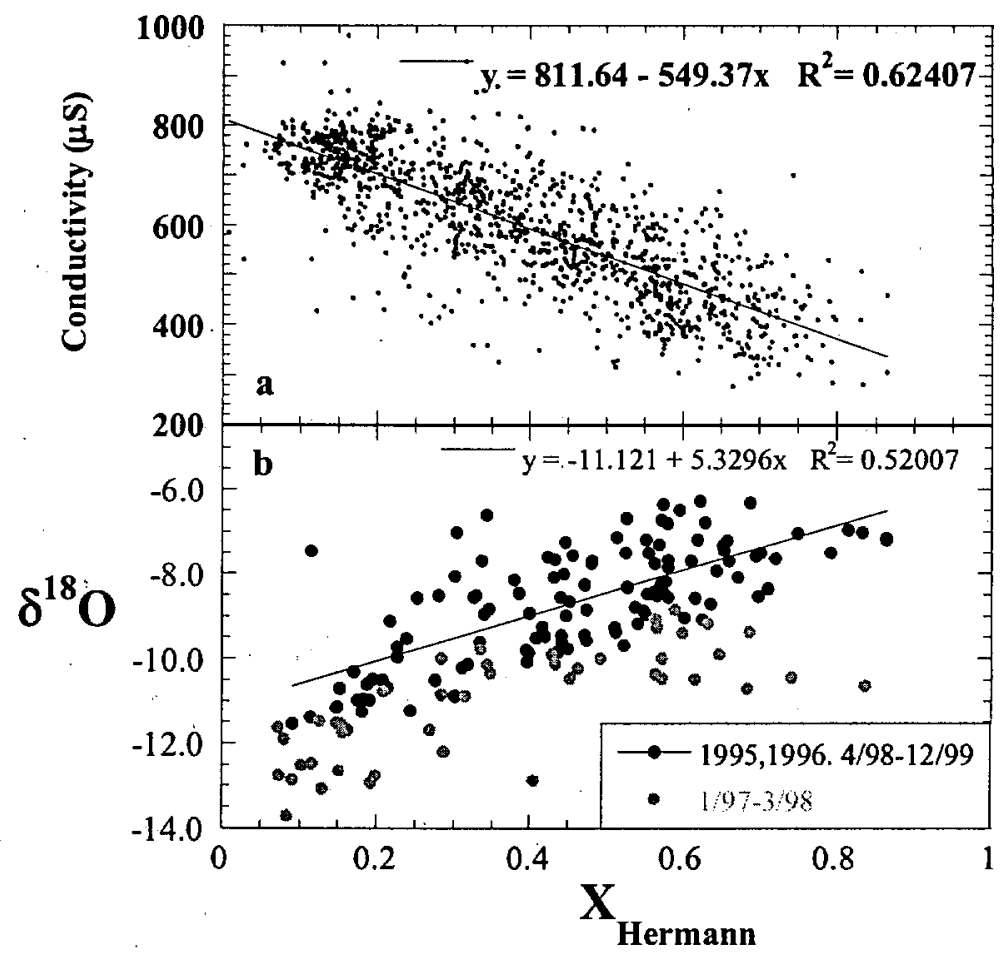

Figure $7 \mathrm{a}$ and $7 \mathrm{~b}$. The fraction of downstream discharge $\mathrm{X}$ correlates linearly with the conductivity and $\delta^{18} \mathrm{O}$ of the Missouri River water, indicating two principle sources of inorganic water quality.

such as $\mathrm{NO}_{3}, \mathrm{Cl}, \mathrm{K}$, turbidity, and microbiology showed poor correlation to the fraction of flow. In these cases, either more than two sources contribute these constituents to discharge measured at Howard Bend, or in-stream processes are significantly changing their concentrations. For example, turbidity requires a settling velocity term to accurately describe its transport, whereas dissolved constituents move with the water unless retarded by some chemical reaction. 

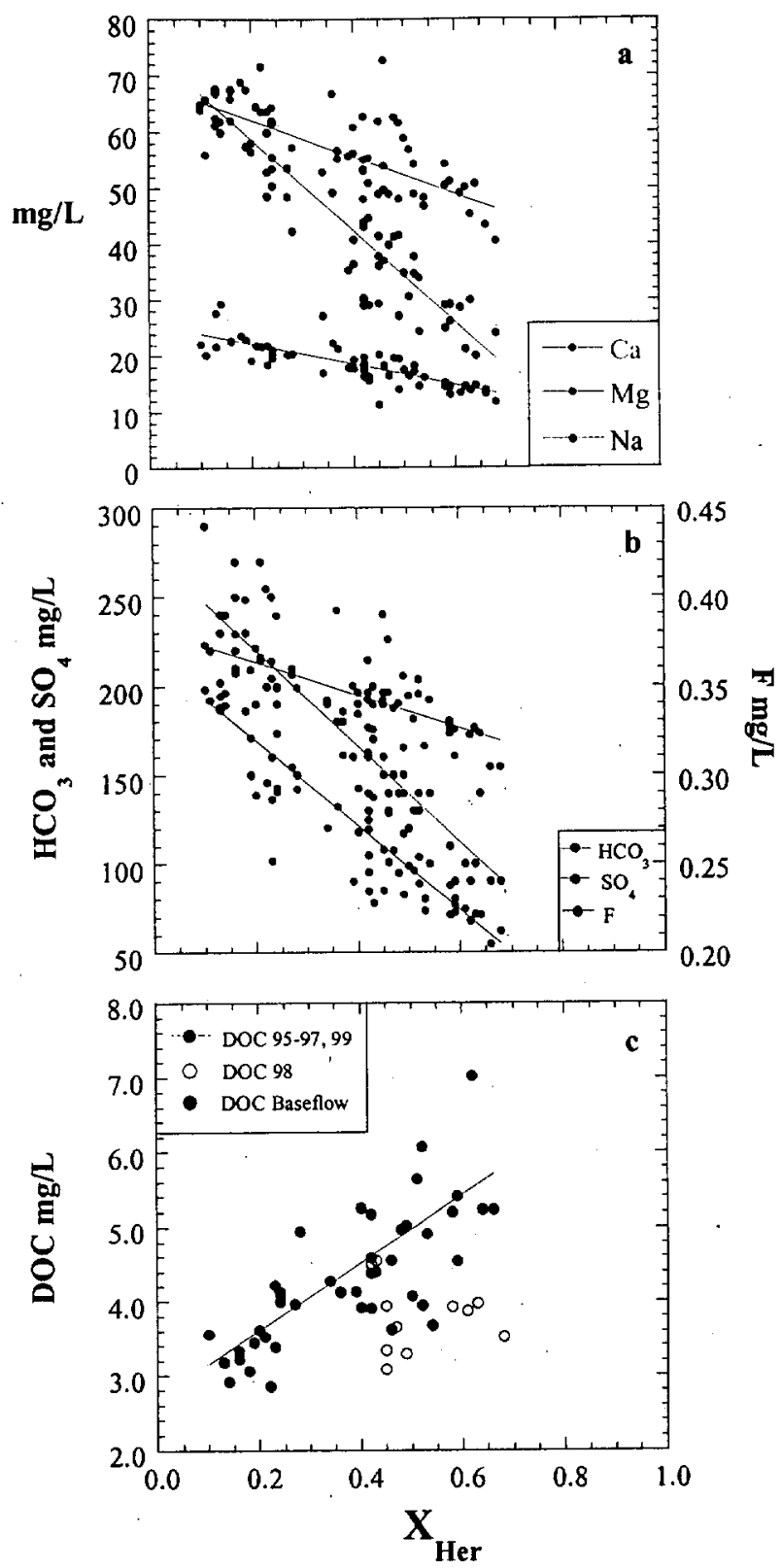

Figure 8abc. The fraction of downstream runoff correlates with monthly average inorganic ions contributing to conductivity. The monthly average DOC concentration also correlates with the $X_{\mathrm{Her}}$ parameter, suggesting a simple two source model for its origin. Exceptions are baseflow (January only), where groundwater discharge may influence concentration, and during El Nino DOC was unusually low.

\section{Dissolved Organic Carbon (DOC)}

The correlation between the fraction of discharge and DOC (Fig 8c) is a key result in this study and some details of this correlation need clarification. For example, DOC 
concentrations for the E1 Nino period of 1997-1998 were unusually low and were not included in the linear regression. It is still unclear why the DOC was low during this period, although an unusually steady baseflow period persisted from June, 1997 to March, 1998, and the spring runoff pulse in 1997 was fragmented and not persistent. However, the total discharge over the year, and also from March through July of each year, was similar between El Nino and non-El Nino years. The monthly average DOC values from before El Nino (1995-1997) show a stronger correlation with $\mathrm{X}_{\mathrm{HER}}\left(\mathrm{R}^{2}=\right.$ $0.78)$, and an equally strong inverse correlation with $\mathrm{EC}\left(\mathrm{R}^{2}=0.80\right)$. Also separated from the linear regression of Figure 8c are DOC values for January of each year that is plotted. This month is always marked by a minimum baseflow period, and DOC values unpredictably vary probably due to groundwater contributions.

Even though monthly average DOC correlates to fraction of discharge, the daily values show a poor correlation. This suggests local effects control the instantaneous DOC concentration, which may include 1) various local geographic sources contributing shortterm DOC loads, 2) algal blooms, 3) rainfall and runoff intensity, and 4) season. Given these as additional variables contributing to DOC on a daily basis, they still represent second-order variables in regards to major sources of DOC. In particular, since the DOC monthly averages correlate to the fraction of downstream discharge, regional geography represents the first-order control on DOC source.

\section{$\underline{\text { DOC Concentration and Humic Content }}$}

Ten samples of Missouri River were collected at Howard Bend over the course of one year for detailed isotopic analysis of DOC (Table1). In particular, the ${ }^{14} \mathrm{C}$ and ${ }^{13} \mathrm{C}$ 
abundance were measured on the DOC and the humic fractions isolated for some samples. The DOC concentration was measured both by LLNL and the City of St. Louis, and analyses agree well $( \pm 0.25 \mathrm{mg} / \mathrm{L})$

The DOC concentration varied from $<3 \mathrm{mg} / \mathrm{L}$ to $>5 \mathrm{mg} / \mathrm{L}$ among the ten samples. The lowest concentration was in late summer of 1997 during a long baseflow period. Highest concentration was during spring runoff in 1998. The DOC concentrations of these ten samples show little correlation to daily discharge in the Missouri River. Typically, the DOC concentration is higher on average during the spring to early summer corresponding to seasonal snow melt and rain storms (Fig. 9). Instantaneous DOC concentrations do not form a simple linear correlation with discharge, and during the period for which these ten samples were collected (E1 Nino), the DOC concentrations were unusually low.

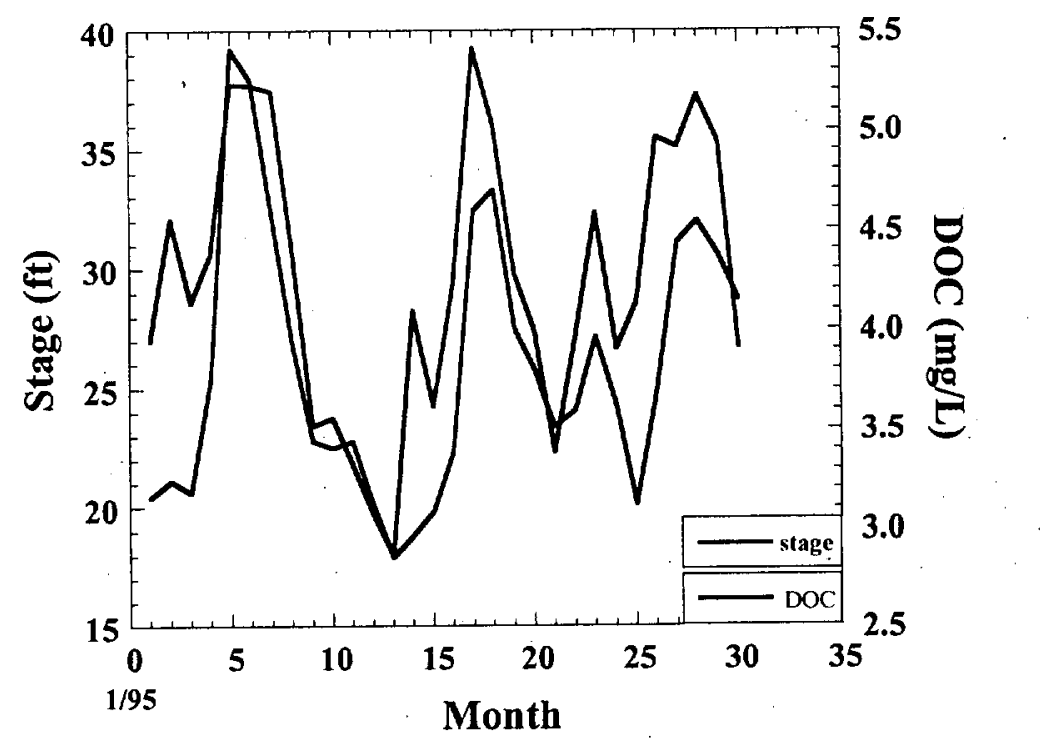

Figure 9. Monthly average DOC values generally follow monthly stage (and discharge) of the Missouri River at St. Louis. Daily values show a more poor correlation.

The humic content was determine on 6 of the ten samples collected by using non-ionic resin techniques (XAD-8) already outlined above. The humic content ranged between 
$43 \%$ and $61 \%$ of the DOC. The lowest were during September, 1997 and February, 1998 during low flow periods. The percent humic content did not correlate with the fraction of downstream discharge $\left(\mathrm{X}_{\mathrm{HER}}\right)$. The humic fraction was dominated by fulvic acids, as indicated by low humic acid yields after acidification of XAD- 8 eluates. Low concentrations of humic acids are typical for river and stream humic substances (Malcolm, 1985), whereas humic acid is the dominant humic substance in soil organic matter.

\section{$\underline{\text { Radiocarbon of DOC and Humic Fractions }}$}

The ${ }^{14} \mathrm{C}$ content of DOC was measured on all ten samples collected and ranged from 115 pmc to 94 pmc (Fig. 10). The highest values were in September, 1999 and February, 1998. The lowest ${ }^{14} \mathrm{C}$ content was in the sample collected in January, 1998. The variation in ${ }^{14} \mathrm{C}$ content did not correlate with river discharge, the fraction of downstream discharge, or DOC concentration.

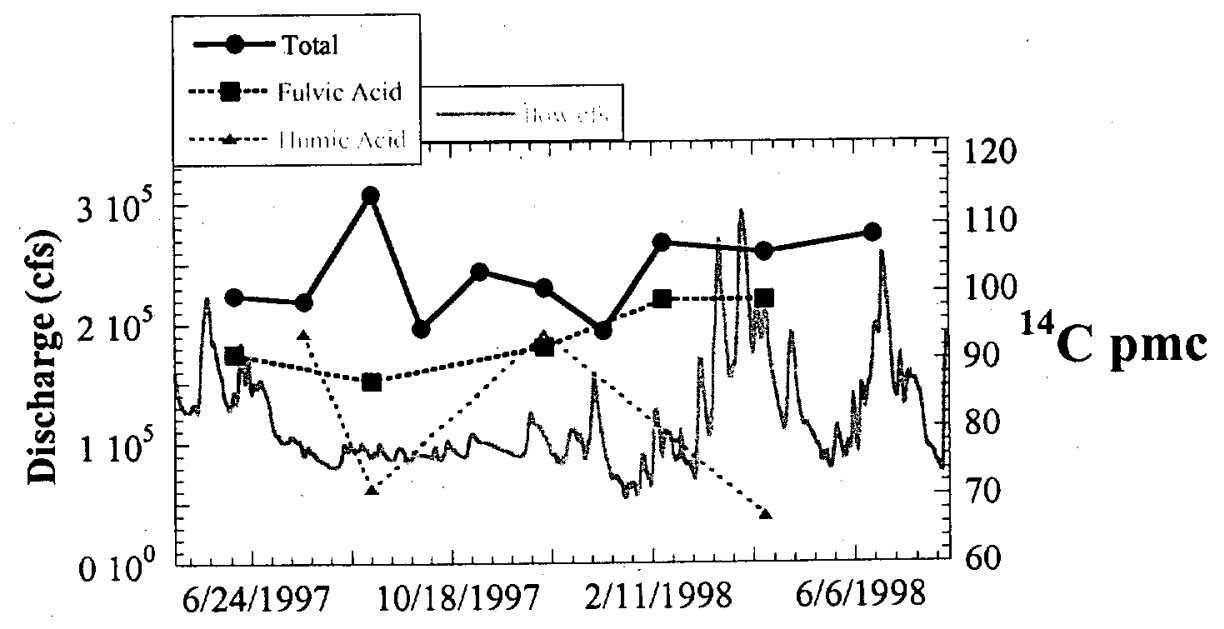

Figure 10. The ${ }^{14} \mathrm{C}$ abundance in $\mathrm{DOC}$ and humic fractions of $\mathrm{DOC}$ show variation during the course of one year that do not correlate to discharge. The humic fractions are distinctly older than the bulk DOC. 
Of particular note, however, is a correlation between the ${ }^{14} \mathrm{C}$ content of DOC and the ratio of humic substances to DOC (Fig. 11). In this case, the ${ }^{14} \mathrm{C}$ content of the DOC decreases with increasing humic content. This indicates that the humic substances have an older mean age than the DOC, as also seen in the fulvic and humic acid fractions (Fig. 10). Providing that the data relation varies on a linear scale, the regression suggests that for a given $\mathrm{DOC}$ with no humic content (Humic/DOC $=0$ ), the ${ }^{14} \mathrm{C}$ would be $140 \mathrm{pmc}$, whereas if the DOC was $100 \%$ humic (Humic/DOC $=1$ ), then the ${ }^{14} \mathrm{C}$ would be $63 \mathrm{pmc}$. These postulated end-member ${ }^{14} \mathrm{C}$ values are not inconsistent with environmental levels of fallout radiocarbon, or with mean ages of soil organic matter (e.g. Trumbore, 1993).

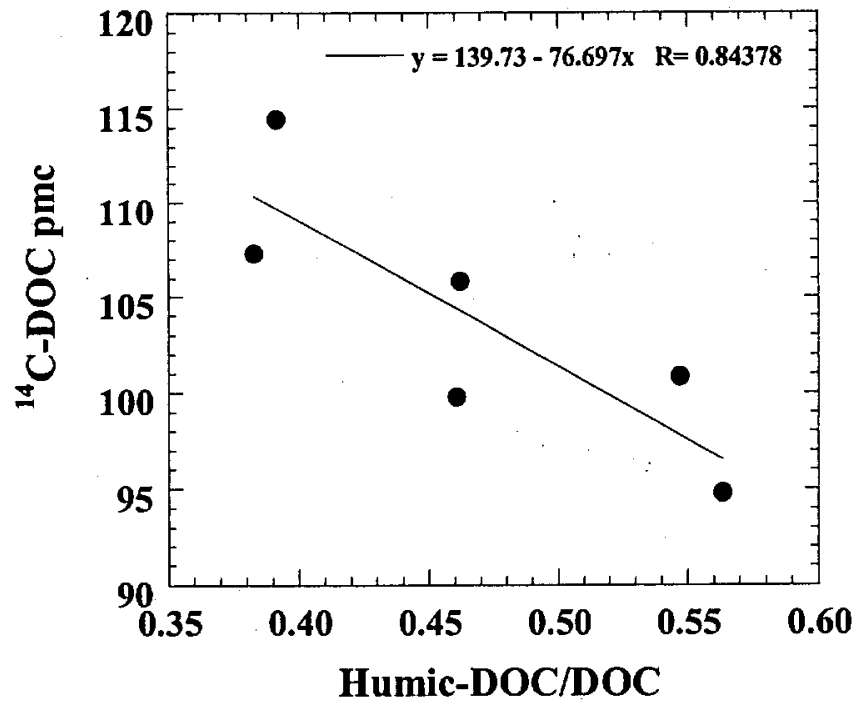

Figure 11 . The ${ }^{14} \mathrm{C}$ abundance of bulk DOC inversely correlates with the fractional amount of humic content, indicating the humics carry the older radiocarbon signature.

The ${ }^{14} \mathrm{C}$ of the 6 fulvic acid fractions isolated varies from $99 \mathrm{pmc}$ to $87 \mathrm{pmc}$, where 4 humic acids measured range from $94 \mathrm{pmc}$ to $67 \mathrm{pmc}$ (Fig. 10). The ${ }^{14} \mathrm{C}$ content of the fulvic acid fraction shows the most remarkable linear correlations with electrical conductivity and the fraction of downstream discharge (Figs. 12ab). These parameters are 
both indicators of water source in the lower Missouri River, and given their excellent correlation with the ${ }^{14} \mathrm{C}$ of fulvic acids, suggests that the latter transports conservatively with the water. The source of fulvic acids are distinguished by their ${ }^{14} \mathrm{C}$ variation. Recall from the previous discussion that the mean electrical conductivity of upper Missouri River discharge was $838 \mu \mathrm{S}$, where lower Missouri River runoff averaged $219 \mu \mathrm{S}$. Using the linear regression in Figure 12a, the ${ }^{14} \mathrm{C}$ of the fulvic acids for these end-members are respectively $83 \mathrm{pmc}$ and $122 \mathrm{pmc}$. This indicates the mean age of the upper Missouri River humics is much older than that of the lower Missouri.
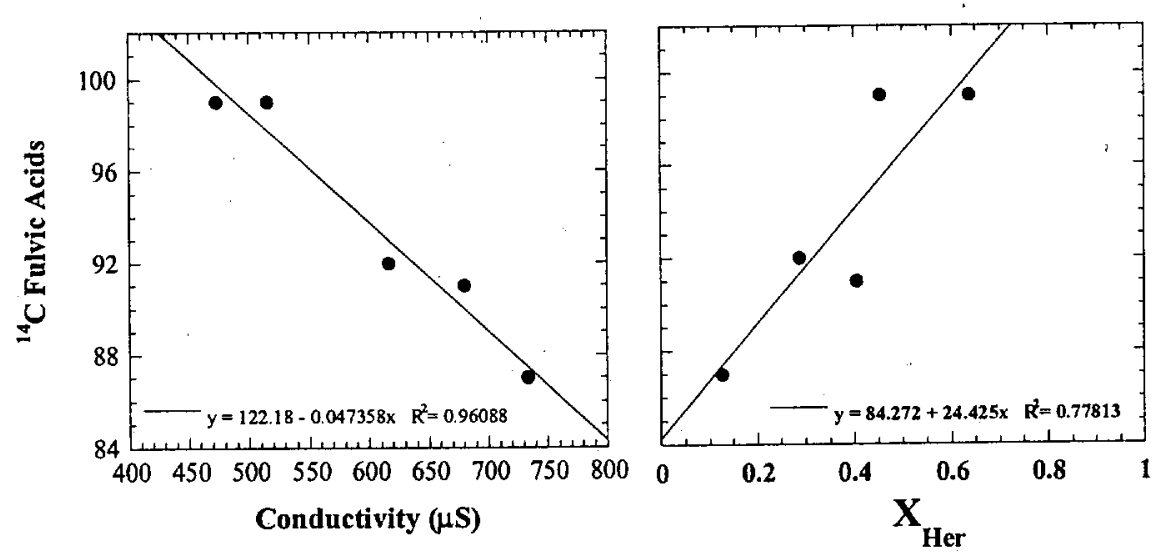

Figure $12 \mathrm{ab}$. The ${ }^{14} \mathrm{C}$ abundance of the fulvic acid fraction of DOC is highly correlated with the conductivity of Missouri River water, and also correlates well with the fraction of downstream discharge.

\section{Geographic Significance of Humic Radiocarbon}

Recall that the climate is variable within the Missouri River watershed. The lower Missouri is dominated by southern deciduous woodland vegetation and has a temperate to humid climate with mean annual precipitation averaging $40 \mathrm{in} / \mathrm{yr}$. The upper Missouri is mostly mixed prairie grassland of more arid and seasonal climate with mean annual precipitation averaging $\sim 20 \mathrm{in} / \mathrm{yr}$. The headwaters of the Missouri River are the eastern Rocky Mountains of Wyoming and Montana. Vegetation in these areas is mixed alpine 
forest. Annual precipitation is mostly as snow. Most of the snowmelt is impounded annually in five large reservoirs operated by the Army Corps of Engineers on the upper Missouri River. The reservoirs' storage likely contributes to evaporation, which increases conductivity of upper river flow.

Climate and vegetation control the quantity and character of dissolved humic substances in the river water (e.g. Thurman, 1985). This is due to the fact that fulvic and humic acids represent the most soluble fraction of soil organic matter, which is the largest pool of humic substances in the aquatic environment (Malcolm, 1985; Aiken and Malcolm, 1987). The different vegetative regimes in the Missouri River watershed are controlled by the variable climate, which results in different soil types. For example, woodland forests like the lower Missouri River area have relatively high primary productivity rates. Carbon turnover in the ecosystem can be large and high precipitation rates contribute to annual soil flushing. Deep root systems contribute to appreciable weathering of soils and likely reduce their organic matter retention capacity. Annual leaf litter produced from deciduous trees also contributes to DOC and modern ${ }^{14} \mathrm{C}$ in the river, which can have soluble components with humic character (i.e. hydrolyzable tannins, see Wershaw et al., 1996).

In the grassland dominated region of the Missouri River, the soil organic matter content can be significantly higher. It results mainly from the annual growth of natural grasslands, where spring warming and aerial precipitation contribute to an intense growing season. As temperatures warm and precipitation tapers back, grasses decrease productivity. They eventually die back as temperatures cool. The lower precipitation rates limit the amount of leaching of residual organic matter, and likely reduction in microbial 
degradation. Also, grasses have shallow root structures and do not create a deep and weathered soil profile. This increases the soil retention capacity for organic matter and slows turnover times by reducing its solubility. This could explain the lower average DOC concentration in discharge originating above St. Josephs, MO. Most importantly, the carbon retention in the soils together with lower NPP contribute an older humic substances to upper watershed discharge.

\section{Relationship Between Humic Radiocarbon and Climate}

To further test the hypothesis that the ${ }^{14} \mathrm{C}$ of the fulvic acids in Missouri River water were controlled by climate differences in the watershed, several samples of humic substances were collected from different rivers throughout the western hemisphere and measured. These were kindly provided by Jerry Leenheer at the US Geologic Survey, Denver, and represent the hydrophobic acids (fulvic + humic acids) isolated from each river sample. River samples ranged from equatorial regions of Venezuela to polar sites in Alaska. Also, one humic ${ }^{14} \mathrm{C}$ value was extracted from Hedges et al. (1986) measured on DOC in the Amazon River.

Bomb-pulse concentrations were observed for equatorial samples in the Amazon River and the Temi River of Venezula (Fig. 13). Bomb-pulse was also observed in humics collected from semi-tropical climates of southeastern Georgia (Suwannee River), and in southern Louisiana (Lake Calcasieu). The San Joaquin River humics of central California (discussed later) also had modern carbon, along with two high latitude samples collected from the Kenai Pennisula (Hidden Lake Creek) and the North Slope of Alaska (Sagav. River). The Missouri River at St. Louis, MO was variable as already shown, ranging from 
87 to $99 \mathrm{pmc}$, depending on the timing of the sample. The humics in Clear Creek, a small stream draining the eastern Rockies in central Colorado, was 85 pmc. Lastly, two samples were collected from eutrophic lakes of central Nebraska (Island Lake) and western Nevada (Big Soda Lake). Their ${ }^{14} \mathrm{C}$ was 87 and 77 pmc, respectively.

Mean radiocarbon ages of dissolved humic substances in these surface waters throughout the western hemisphere form a positive correlation with local mean annual precipitation (Fig. 13). Mean annual precipitation is a simple first-order measure (exponential curve fit) of net primary productivity in terrestrial ecosystems (Schlesinger, 1997). Bomb-pulse ages are consistently observed for dissolved humic substances in humid to tropical climates, whereas temperate to semi-arid climates mean ages can be up to 1500 years old. The established similarity between riverine dissolved humic substances and degradation products of terrestrial vegetation in soil and plant litter (e.g. Wershaw et al., 1996), suggest that the age-climate correlation is linked to the rate of local primary productivity. However, the range in observed ages indicates a significant retardation before solubilization of dissolved humic substances into rivers and streams, which is likely controlled by the extent of weathering and carbon sequestration capacity of soil (e.g. Torn et al., 1997). The correlation indicates that the mean age of the humic fraction of DOC in rivers increases with decreasing net primary productivity. Since the hydrophobic acid fraction of DOC (humic substances) is predominantly soil derived, the correlation indicates that soil carbon storage rates likely dictate the humic and ${ }^{14} \mathrm{C}$ content of the stream DOC. In detail, in equatorial tropical regions the ${ }^{14} \mathrm{C}$ content is bomb-pulse as shown by Hedges et al. (1986), with a mean age $\leq 40$ years, and DOC content (and humic content) is high. In temperate to semi-arid regions, the ${ }^{14} \mathrm{C}$ content of the humic 
fraction has little bomb pulse: Calculated mean ages are as old as 1500 years. Also the humic content and the DOC concentration are much lower than in tropical rivers.

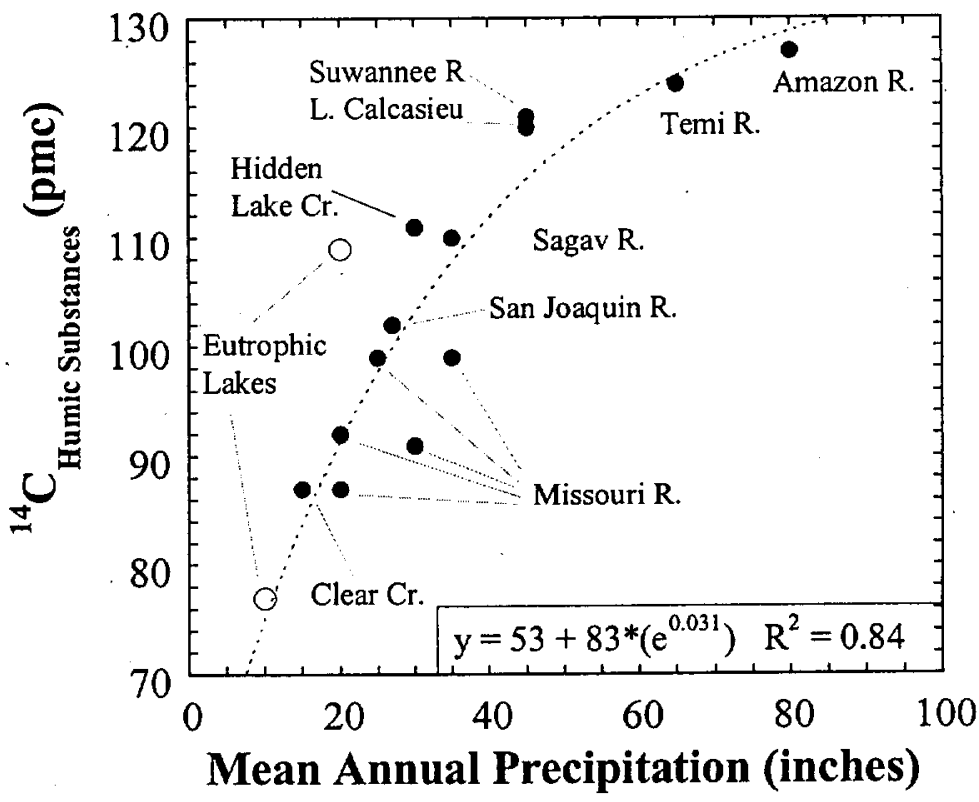

Figure 13. The ${ }^{14} \mathrm{C}$ abundance of the hydrophobic fraction (humic substances) of DOC in several rivers correlates well with the mean annual regional precipitation from each sample location. The abundance is also likely related to relative solubility rates of soil carbon entering the rivers.

In general, the ${ }^{14} \mathrm{C}$ content correlates with net primary productivity of regional ecosystems as suggested by the mean annual precipitation. However, the range in mean ages suggested by the ${ }^{14} \mathrm{C}$ content (factor of 40 ) are far greater than the range in net primary productivities measured in these environments as well as the mean annual precipitation. Furthermore, it is also known that the content of soil organic matter is quite variable among these environments. In tropical regions, the soil organic matter is appreciably lower in temperate regions. Factors such as highly weathered soils deficient in divalent cations, intense microbial actions, frequent rain, and high productivity contributes to the flushing or re-incorporation of DOC into the ecosystem. As already 
illustrated for the Missouri River, temperate to semi-arid regions have less weathered soil profiles, lower productivities, and less frequent soil-flushing. This contributes to higher soil organic content and longer storage or turnover times into the aquatic environment. This is particularly prevalent in grassland regions. Soil weathering may be the most significant control on carbon storage in addition to net primary productivity. Less weathered soil is more abundant in divalent cations, which sequester humic substances. In humid to tropical region, soils are depleted in divalent cations, which contributes to rapid flushing of soil organic matter, lower storage times, and high humic substance content with large nominal size (Aiken and Malcolm, 1987).

\section{Carbon-13 Content of DOC and Humic Fractions}

The $\delta^{13} \mathrm{C}$ value was analyzed on the same samples as the ${ }^{14} \mathrm{C}$. The $\delta^{13} \mathrm{C}$ value of bulk DOC changed approximately 2.5 per mil over the course of one year (Fig. 14). The lowest values were during the wintertime at near baseflow conditions, whereas high values were associated with warmer periods and higher flow. Note that the $\delta^{13} \mathrm{C}$ of the DOC somewhat parallels the annual temperature cycle in the Missouri River, where lower temperatures correlate with more negative values (Fig. 15). The $\delta^{13} \mathrm{C}$ of the DOC does not correlate with ${ }^{14} \mathrm{C}$ or the humic fraction of the $\mathrm{DOC}$ as seen for the ${ }^{14} \mathrm{C}$. This suggests that the $\delta^{13} \mathrm{C}$ is controlled by a process somewhat de-coupled from that controlling the ${ }^{14} \mathrm{C}$. The $\delta^{13} \mathrm{C}$ values of the fulvic acid are consistent with previous observation (Thurman, 1985). The fulvic acid fraction does not vary to any significance among the samples measured. This suggest that these soluble humic fractions, likely 
originating from plant litter or soils in different parts of the watershed, are not controlled plant sources with $C 3$ and $C 4$ metabolic pathways, as suggested by Bird et al. (1992). The

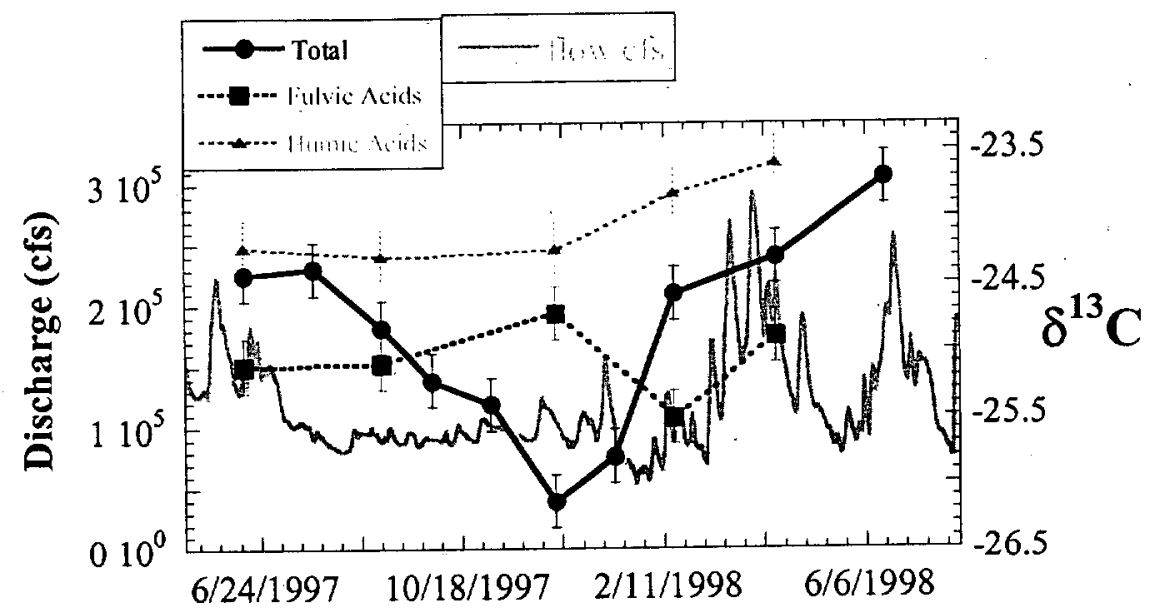

Figure 14. The $\delta^{13} \mathrm{C}$ value of bulk DOC varies over 2 per mil during the course of one year, consistent with but of lower variability than POC observed by previous workers (Bird et al., 1998 and Barth et al., 1998). The humic fractions show only minor $\delta^{13} \mathrm{C}$ variations suggesting that the bulk $\delta^{13} \mathrm{C}$ variations are not linked to vegetation type, but rather algal production.

$\delta^{13} \mathrm{C}$ of the humic acid fraction (typically $\leq 10 \%$ of hydrophobic fraction) is much higher and also shows little variation among the samples measured. The humic acid values are similar to high $\delta^{13} \mathrm{C}$ values measured in decomposed forest soil organic matter (Nadelhoffer and Fry, 1988). The $\delta^{13} \mathrm{C}$ of humic acid and their low concentration in the water are consistent with humic acids having low solubility and being closely associated with soil organic matter (e.g. Stevenson, 1985).

The small $\delta^{13} \mathrm{C}$ variation in the humic fraction of the DOC indicates that most of the seasonal variability of $\delta^{13} \mathrm{C}$ is in the non-humic portion. This and the close relation of the $\delta^{13} \mathrm{C}$ variation to water temperature suggest that this non-humic portion comprises variable amounts of soluble detritus originating probably from algal material. To 


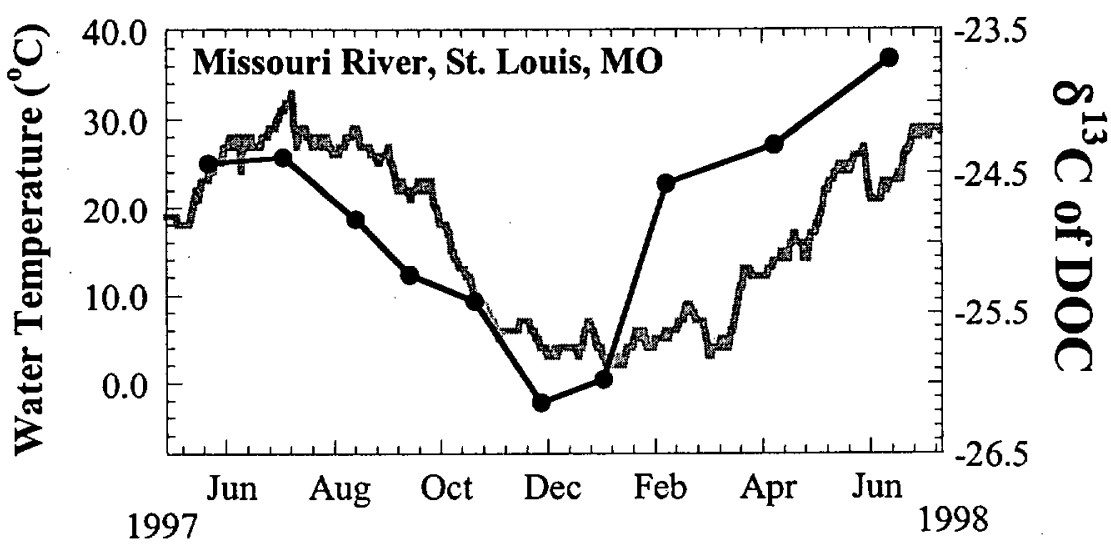

Figure 15. The $\delta^{13} \mathrm{C}$ of bulk DOC in the Missouri River varies closely with water temperature, suggesting a relationship with autochthonous sources of DOC.

determine if the amount of DOC originating from algal material is plausible, a mass balance equation is constructed to calculate the ratio of algal DOC to total DOC. It follows that this ratio can be defined by

$$
\frac{D O C_{\text {alg }}}{D O C_{\text {tot }}}=\frac{\frac{\delta^{13} C_{\text {non }- \text { alg }}}{D O C_{\text {tot }}}+\frac{D O C_{h m}}{D O C_{t o t}} \delta^{13} C_{h m}-\delta^{13} C_{t o t}}{\delta^{13} C_{\text {alg }}-\delta^{13} C_{\text {non - alg }}}
$$

where subscripts alg, non-alg, tot, and $h m$ refer to, respectively, algal component of DOC, non-algal portion of non-humic DOC (e.g. low molecular weight acids), total DOC, and the humic substance portion of DOC. If we assume that the $\delta^{13} \mathrm{C}_{\mathrm{agg}}$ is -23 per mil (Thurman, 1985), and the $\delta^{13} \mathrm{C}_{\text {non-alg }}$ is -28 per mil, then $\mathrm{DOC}_{\text {alg }} / \mathrm{DOC}_{\text {tot }}$ ratio can be calculated. Results are plotted against the fraction of humic content in Figure 16. The highest algal DOC ratio is for a sample collected in late summer at near baseflow conditions. This sample was collected when upstream discharge comprised $88 \%$ of the flow $\left(\mathrm{X}_{\mathrm{HER}}=0.12\right)$. At baseflow in mid-winter, when algal production is anticipated to be minimal, the mass balance suggests algal DOC should be nearly absent. The remaining samples represent late winter to early summer runoff. The linear inverse correlation in 
Figure 16 has a y-intercept of nearly 0.5 , suggesting that end-member, the water could have nearly half its DOC from algal origin and absent of humics substances. This endmember may be realistic for shallow reservoir water (e.g. above thermocline) in the upper watershed during the summertime, but more than likely the Missouri River channel itself does not have the requisite surface area to supply this fixation capacity and also be free of humic substances.

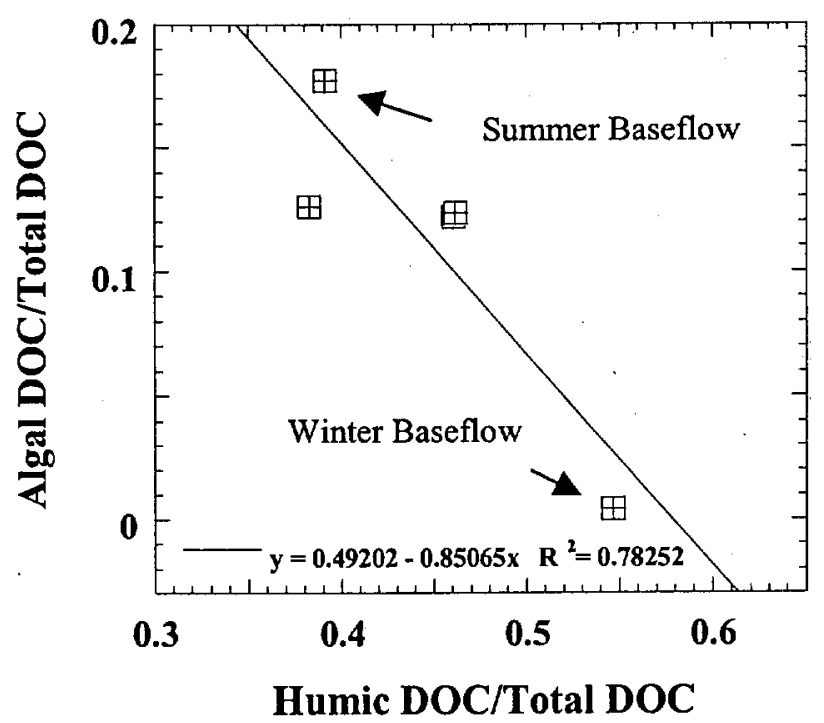

Figure 16. Algal DOC was calculated by mass balance using the DOC concentrations, humic fraction and the $\delta^{13} \mathrm{C}$ values. The highest and lowest algal content correlate to summer baseflow and winter baseflow, respectively.

\section{Results and Discussion on Other Midwest Rivers}

\section{Rivers and Springs in St. Louis Area}

St. Louis was an ideal location for field collection for a variety of river samples.

Within an $\sim 50$ mile radius, the Missouri River, Mississippi River, Illinois River, and the

Meremac River, draining central Missouri, could be sampled in one day. Quarterly samples were collected from these sites along with field parameters, and analyzed for DOC, $\delta^{18} \mathrm{O}, \delta^{13} \mathrm{C}_{\mathrm{DIC}},{ }^{14} \mathrm{C}_{\mathrm{DIC}}, \delta^{13} \mathrm{C}_{\mathrm{DOC}},{ }^{14} \mathrm{C}_{\mathrm{DOC}}$ (Table 2). Additional samples were 
collected during spring runoff, one time only, for several small rivers in central Missouri, some of which are tributary to the Missouri River. In addition, the Missouri River at St. Joseph, MO and the Kansas River at Kansas City was collected. Lastly, two spring waters from the Meremac River Basin (Meremac Spring and Rockwood Spring) were collected for analysis of local groundwater.

River water in the St. Louis area had variable conductivity over the course of one year, with the Mississippi River showing only moderate change. The upper Mississippi drains Minnesota, Wisconsin, most of Iowa, and northern Missouri, representing a region with less climate variability than occurs in the Missouri River Basin. Furthermore, geologic exposure is less diverse in the Mississippi River, which likely reduces geographic variability in differential rock dissolution. Also, the lack of major reservoirs on the Mississippi reduces evaporative enrichment of the river water.

The Illinois River shows a large variation in conductivity similar to the Missouri River. However, the Illinois River has a much smaller watershed $\left(29,000 \mathrm{mi}^{2}\right)$, and is dominated by agriculture, representing the heart of the mid-western corn-belt. The high conductivity suggests dissolved salt enrichment within the basin.

The Meremac River is a groundwater-dominated flow draining predominantly Paleozoic-age carbonate rocks with karst-type erosion. Meremac Spring is a first magnitude spring flow and forms the headwaters of the river. The conductivity was modestly variable, due mostly to changes from groundwater input (see Fredrickson and Criss, 1999).

The variability in DOC and $\delta^{18} \mathrm{O}$ was similar to the variability in conductivity among these rivers. The DOC varied 1.2 and $5.1 \mathrm{mg} / \mathrm{L}$ with the lowest in the Meremac River at 
baseflow, which was similar to Meremac Spring. The $\delta^{18} \mathrm{O}$ in the Mississippi River changed modestly, but due to lower mean elevations in the watershed, varied less than the Missouri River. The Illinois and Meremac Rivers showed only minor changes. Storm flows have been shown to only modestly perturb the $\delta^{18} \mathrm{O}$ of Meremac River water due to high groundwater discharge (Fredrickson ands Criss, 1999).

The $\delta^{13} \mathrm{C}_{\mathrm{DIC}}$ of St. Louis area rivers are consistent with previous measurements on similar rivers in the northern hemisphere (e.g. Hitchon and Krouse, 1972), suggesting limited atmospheric exchange, indicated by the moderately low values between -4.5 and -12.9 per mil. The lowest value was actually measured in the Mississippi River above St. Louis (i.e. Winfield Ferry). This occurred during high flow in March, 1997. This sample also had a low ${ }^{14} \mathrm{C}_{\mathrm{DIC}}$ value of $85 \mathrm{pmc}$, suggesting a large groundwater contribution to discharge. Low flow and summertime samples in the Missouri and Mississippi Rivers showed higher ${ }^{13} \mathrm{C}$ and ${ }^{14} \mathrm{C}$ values, presumably from modest atmospheric exchange. The Illinois River was less predictable, since the ${ }^{14} \mathrm{C}$ was low during the summer and high in the fall. In the Meremac River, the ${ }^{13} \mathrm{C}$ and ${ }^{14} \mathrm{C}$ showed a linear correlation $\left(\mathrm{R}^{2}=0.94\right)$, reflecting different groundwater input. Groundwater in the carbonate rocks in this basin should show increased $\delta^{13} \mathrm{C}_{\mathrm{DIC}}$ and a simultaneous decrease in ${ }^{14} \mathrm{C}_{\mathrm{DIC}}$ as it geochemically equilibrates with the rock (i.e. $\delta^{13} \mathrm{C} \sim 0$ per mil, ${ }^{14} \mathrm{C}=0 \mathrm{pmc}$ ).

The $\delta^{13} \mathrm{C}_{\mathrm{DOC}}$ and ${ }^{14} \mathrm{C}_{\mathrm{DOC}}$ values, for river samples measured, consistently show young carbon sources with post nuclear-age carbon input (i.e. $>100 \mathrm{pmc}$ ), and have $\mathrm{C} 3$ plant $\delta^{13} \mathrm{C}$ values. The exception is the Kansas River sampled in April, 1998, which had a higher $\delta^{13} \mathrm{C}_{\mathrm{DOC}}$ value (-22.5 per mil) observed in all other rivers, and hints at a possible $\mathrm{C} 4$ contribution (e.g. grass). The lower ${ }^{14} \mathrm{C}_{\mathrm{DOC}}$ value of Missouri River at Lewis Bridge 
collected in March, 1997 (97pmc) is an exception to younger carbon sources, but as outlined above, low values would be periodically expected in this river. The other rivers drain basins that are presently, or previously were, dominated by deciduous forest, where higher soil carbon turnover is expected.

\section{Other Rivers in State of Missouri}

Two observations worth pointing out for these samples are the high DOC concentrations for small rivers sampled during spring runoff in central Missouri. Note the concentration ranged between 5.8 and $8.4 \mathrm{mg} / \mathrm{L}$. Note also the low conductivity numbers ranging from 128 to $309 \mu \mathrm{S}$. The high DOC concentrations and low conductivity values for these rivers are consistent with the trend in the lower Missouri River, where increased DOC and decreased EC correlate with increased downstream runoff (i.e. $\mathrm{X}_{\mathrm{HER}}$; see Figs. $7 \mathrm{a}$ and $8 \mathrm{c})$.

\section{Results and Discussion on California Rivers \\ Elevation and Climate Control on Water Quality}

Sample locations and descriptions for Califorina Rivers are listed in Table 3, and all the measurements performed are in Table 4 . California is bordered on its eastern side by the Sierra Nevada Mountains, rising greater than $14,000 \mathrm{ft}$ in some places. The annual snowpack supplies the majority of the water used in the state. Annual precipitation varies from $\sim 10 \mathrm{in} / \mathrm{yr}$ in the Central Valley to $>90 \mathrm{in} / \mathrm{yr}$ as snow-water equivalent in the mountains. As a result, there is a distinct contrast in the dissolved salt content between the upper and lower watersheds of California rivers (Table 4 and Fig. 17a). Electrical 
conductivity of surface runoff in the upper watershed is normally below $100 \mu \mathrm{S}$, while in some areas of the lower San Joaquin River drainage, conductivity can exceed $2000 \mu \mathrm{S}$.
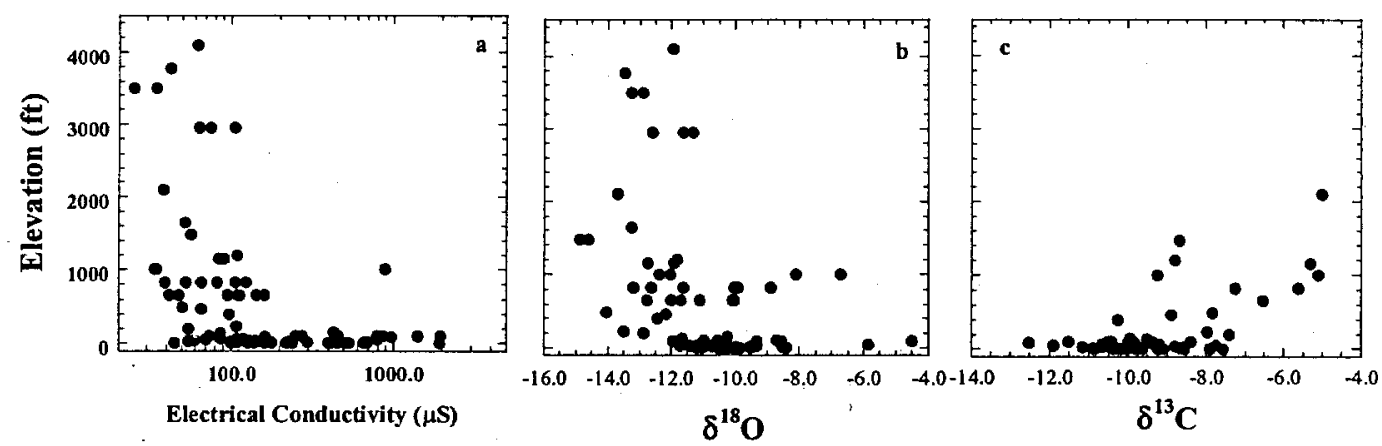

Figures $17 \mathrm{abc}$. The dissolved salt content, measured as electrical conductivity, $\delta^{18} \mathrm{O}$ values, and $\delta^{13} \mathrm{C}$ values of California surface water varies as a function of elevation. Upper watershed runoff has low conductivity and low $\delta^{18} \mathrm{O}$ due to high annual precipitation. The $\delta^{13} \mathrm{C}$ is high in the upper watershed because of low DIC concentrations and likely partial equilibration with atmospheric $\mathrm{CO}_{2}$. Lower watershed runoff accumulates dissolved salts from soil flushing and decreases in $\delta^{13} \mathrm{C}$ due to increased respiration sources. The low $\delta^{18} \mathrm{O}$ values of lower watershed runoff still reflect high elevation sources.

The $\delta^{18} \mathrm{O}$ value of surface water is strongly controlled by elevation in California, due to the steep topographic gradients and storm fronts from the Pacific Ocean that rapidly rise and precipitate moisture (Freidman et al., 1971; Ingraham and Taylor, 1991). The $\delta^{18} \mathrm{O}$ value of upper watershed runoff in California is always depleted in $\delta^{18} \mathrm{O}$ and falls below -12.0 per mil (Fig. 17b). Lower watershed runoff can range from depleted to enriched values. This is due to the fact that most major river flows in the lower watersheds originate from reservoirs storing high elevation, $\delta^{18} \mathrm{O}$-depleted runoff. The exception is surface flows originating from the Coast Range (e.g. Cache Creek and Putah Creek), where elevations are much lower and the closer proximity to the Pacific Ocean preclude depleted $\delta^{18} \mathrm{O}$ values in precipitation.

Ten samples of each major river flow draining the western Sierra Nevada Mountains were collected over the course of one year (Table 5). Sampling points were all located 
above major storage reservoirs in order to measure $\delta^{18} \mathrm{O}$ values of runoff without the effect of evaporation. Average $\delta^{18} \mathrm{O}$ values of each runoff source are compared to the mean elevation above the sampling point (Fig. 18). A strong linear correlation is expected, since $\delta^{18} \mathrm{O}$ of precipitation follows a prescribed variation with increasing elevation (e.g. Ingraham and Taylor, 1991). In fact, the linear correlation among the runoff data closely matches a predicted $\delta^{18} \mathrm{O}$-elevation line derived by Rose et al. (1996).

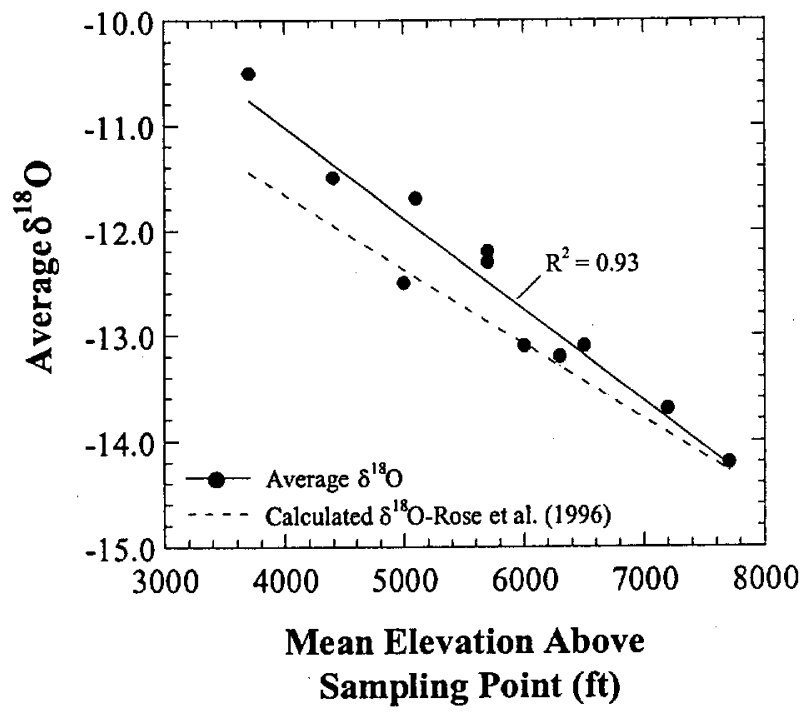

Figure 18. Mean annual $\delta^{18} \mathrm{O}$ values for runoff sampled above major reservoirs on the west side of the Sierra Nevada are highly correlated with elevation, and provides a meaningful fingerprint to runoff source.

The low electrical conductivity of upper watershed runoff is also reflected in the $\delta^{13} \mathrm{C}$ values of DIC. Even though the upper watershed experiences a greater mean annual precipitation, the flux of inorganic carbon from soil and aquatic respiration is limited. The DIC greatly increases downstream in the lower watershed, where soil water contribution and in-stream respiration likely increases. The effect of overall respiration can be seen qualitatively by the $\delta^{13} \mathrm{C}$ values of the DIC (Fig. 17c). The upper watershed values commonly are above -10 per mil or higher, while the lower watershed is as low as 
-12 per mil. This is the same general range in $\delta^{13} \mathrm{C}$ values observed by Aucour et al. (1999) for the Rhone River system.

The major river flows directing surface water to the Delta are the Sacramento and the San Joaquin rivers. The Sacramento River by far exports the greatest amount of surface runoff, having a watershed $>25,000 \mathrm{mi}^{2}$, while the San Joaquin is $\sim 12,000 \mathrm{mi}^{2}$. The mean annual discharge of the Sacramento River, measured below the City of Sacramento, is $24,500 \mathrm{cfs}$ with runoff exceeding baseflow by nearly an order of magnitude. Average annual precipitation in the Sacramento River watershed (36.1 in/yr) is 30\% greater than that of the San Joaquin drainage (27.3inyr). Consequently, the measured discharge at the lower end of the Sacramento River is nearly 10 times greater than that of the San Joaquin River (Fig. 19a). Furthermore, the electrical conductivity of the San Joaquin River can be four times greater than the Sacramento River (Fig. 19b). This disproportional increase in San Joaquin River conductivity occurs along its lower stem through the northern San Joaquin Valley (see below).

The Sacramento and San Joaquin rivers intersect in the Delta region and combine their flows with the two moderate discharges of the Mokelumne River and the Consumnes River. The extent of mixing within the Delta varies greatly with time and space. In general, when Sacramento River flows are high, low salinity water penetrates southward in the Delta, while at baseflow, when pumping demands for the California aqueduct are high, more saline water migrates northward. The intrusion of seawater into the Delta via the San Francisco Bay has been a long-standing concern, particularly during baseflow and droughts. The variable conductivity due to seasonality and changing flow can be seen in the Middle and Old River data of Table 4. Conductivity alone cannot be used as a 
criteria for distinguishing Sacramento from San Joaquin River contributions, since seawater and agricultural irrigation discharge within the Delta also contribute dissolved
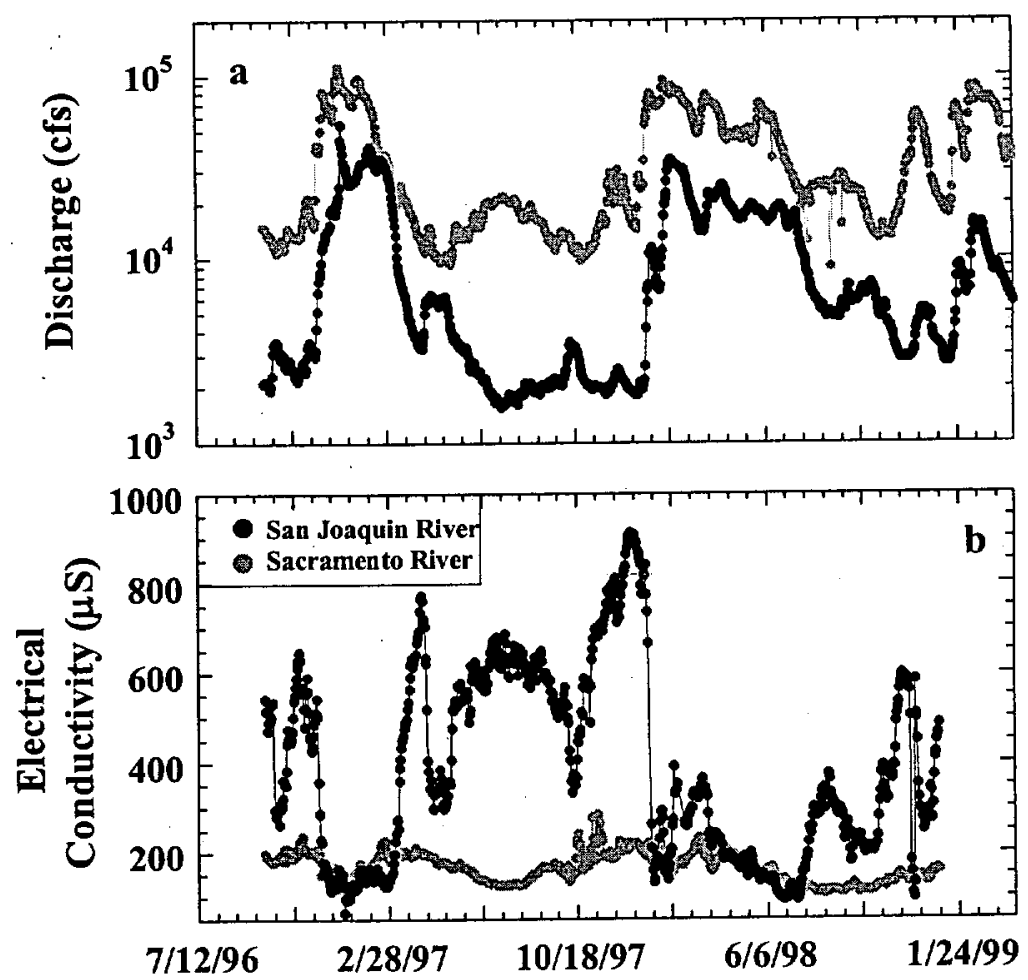

Figure 19ab. Discharge in the lower Sacramento River is nearly an order of magnitude greater than in the lower San Joaquin River, due to a watershed twice as large and $30 \%$ more annual precipitation on average. This disproportional increase in the San Joaquin conductivity is due to agricultural practices in the lower watershed.

salt. At baseflow, the $\delta^{18} \mathrm{O}$ value of the lower Sacramento and San Joaquin rivers differ by only 0.5 per mil (see data from 9/97), and this suggests distinguishing mixtures of these two sources in the Delta is not realistic using this particular isotope measurement. The DOC, $\delta^{13} \mathrm{C}_{\mathrm{DOC}},{ }^{14} \mathrm{C}_{\mathrm{DOC}}$ measurements of California Rivers are consistent with mid-western rivers with a few exceptions. For DOC, concentrations ranged from 1.2 to 9.0mg/L. The low value was in a creek draining the Coast Range (Corral Hollow Cr.), whereas the highest was measured in the San Joaquin River at high discharge. The latter value is unusually high for a larger river, and was distinctly higher than the Sacramento 
River at high discharge (e.g. $4.6 \mathrm{mg} / \mathrm{L}$ ). The San Joaquin has lost considerable natural wetlands over the past 100 years, but remaining soils naturally high in organic matter may contribute to these high DOC concentrations. The $\delta^{13} \mathrm{C}_{\mathrm{DOC}}$ values of all rivers measured are all consistent with $\mathrm{C} 3$ plant sources, ranging between -24.3 and -26.7 per mil.

Most of the ${ }^{14} \mathrm{C}_{\mathrm{DOC}}$ values were consistent with modern carbon sources. The exceptions are baseflow samples of Cache Creek and the Old River. Cache Creek drains a Coast Range watershed north of the Delta, and has one natural and one man-made reservoir in its upper watershed, totaling 0.33 million acre-ft of storage capacity. The river supplies summer irrigation water for the west -side of the lower Sacramento Valley, and agricultural return flows to its channel are common in the summertime. The baseflow sample had a distinct algal-green color. Nevertheless, the low ${ }^{14} \mathrm{C}_{\mathrm{DOC}}$ value $(89 \mathrm{pmc})$ suggests an old source of carbon. This old carbon may be consistent with old soil carbon leached during agricultural irrigation that was preferentially incorporated in the creek discharge. The Coast Range and western Sacramento Valley have a similar climate to the lower elevations of the upper Missouri River, with the exception that snow does not accumulate in the winter.

The ${ }^{14} \mathrm{C}_{\mathrm{DOC}}$ value for the Old River was $>150 \mathrm{pmc}$. This value is unusually high and may suggest a point source. No potential source could easily be identified. A follow up measurement during runoff in February, 1998 showed a more typical ${ }^{14} \mathrm{C}_{\mathrm{DOC}}$ value of 108pmc. The Old River is a natural extension of the San Joaquin River, forming the western-most river channel in the Delta (Fig. 3). This river is the predominant drinking water source for Contra Costa Water District. 
Spatial Variation in Water Quality and Isotopic Values

High conductivity water in California rivers are isolated to those draining the Coast Ranges and small diversions in the lower San Joaquin River basin. Most notably, Putah Creek and Cache Creek drain the Coast Range north of the Delta. Putah Creek is dammed in the upper watershed with a 1.6 million acre-ft storage capacity. It serves as an irrigation water supply for southern Yolo County and a large portion of Solano County, located directly south of the creek channel. Agricultural return flows are also common in this creek, as indicated by a high nitrate concentration of $\sim 38 \mathrm{mg} / \mathrm{L}$ as nitrate. The Coast Range comprises mostly Jurassic to Tertiary-age marine and ultra-mafic rocks, that have been previously recognized as high salt sources (e.g. Presser and Swain, 1990), along with anomalous saline spring discharges (e.g. Davisson et al., 1994). Los Banos Creek, Mud Slough, and Salt Slough all drain lower San Joaquin Valley agricultural areas with naturally high salt levels in soils. The high dissolved salt content of these small flows correlate also to high nitrate levels. Naturally high nitrate levels may occur in these soils, but the profusion of nitrate-based fertilizers in agriculture have been shown to have a direct impact on nitrate levels in regional groundwater (see Davisson and Criss, 1993 and Criss and Davisson, 1996).

Most of the entire length of the San Joaquin River was collected in the space of few days in the fall of 1997 during baseflow. The change in water quality parameters from the upper to lower watershed is dramatic. For example, the conductivity varied from $\sim 56 \mu \mathrm{S}$ in the Sierras to $>850 \mu \mathrm{S}$ just before the river enters the Delta. The $\delta^{18} \mathrm{O}$ and nitrate values have similar changes (Fig. 20a). The low $\delta^{18} \mathrm{O}$ value and nitrate concentration in the 
upper watershed is consistent with snowmelt runoff, while dramatic jumps in their values about 60 miles downstream correspond to agricultural areas of the eastern San Joaquin Valley. Both values are at a maximum on the west-side of the valley at $\sim 110$ miles downstream of the alpine sample. The nitrate decreases steeply after this point, with more gradual decrease in $\delta^{18} \mathrm{O}$. These decreases correspond to external water sources (e.g. California Aqueduct water) entering the San Joaquin River to supplement flow requirements to the Delta. Further downstream, the Merced, Tuolumne, and Stanislaus Rivers discharge dilute Sierran water into the San Joaquin.
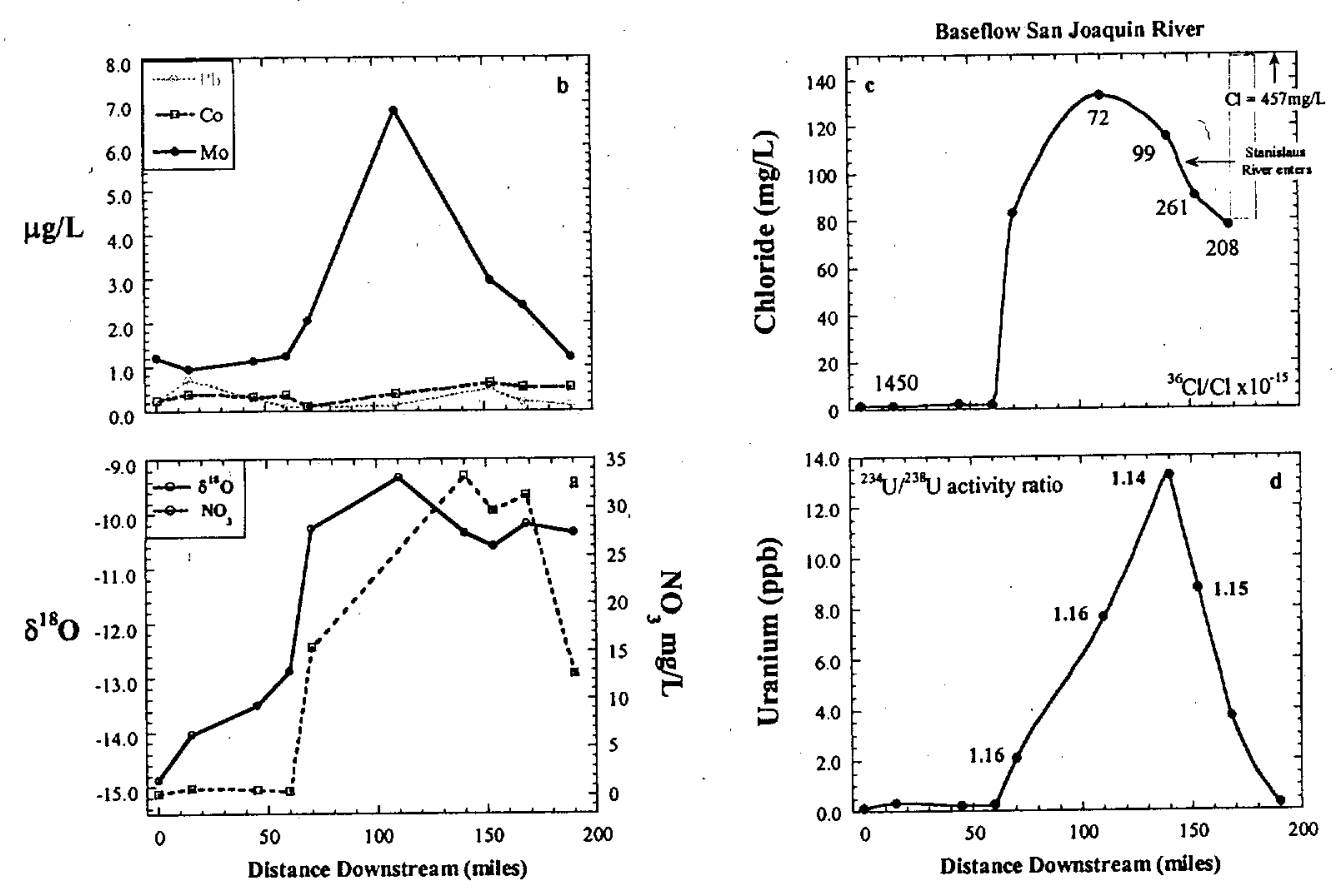

Figure 20abc. The San Joaquin River along its entire length undergoes dramatic water quality change from a dilute, isotopically depleted snowmelt in the Sierra Nevada Mountains (zero distance downstream) to a high conductivity water with high $\mathrm{NO}_{3}, \mathrm{Cl}$, Mo, and $\mathrm{U}$ along its highly manipulated flow in the agricultural areas of the San Joaquin Valley. Uranium and chloride isotopes both indicate a natural source.

Trace metals measured in the San Joaquin indicate that $\mathrm{Pb}$ and $\mathrm{Co}$ either have very low concentration in the high salt source, or their solubility is limited and they are readily scavanged (Fig. 20b). Molybdenum, on the other hand follows the same pattern of 
enrichment as the nitrate concentration, consistent with high concentration in the source and high solubility in river water. Both chloride and uranium are high in the San Joaquin River and follow the same pattern of enrichment (Figs. 20cd). High uranium has been observed in agricultural ponds in the southern San Joaquin Valley, where it tends to accumulate in sedimentary organic matter (Duff et al., 1997ab). The factor of 100 increase in its concentration indicates a high concentration source dispersed along the length of the lower San Joaquin River. The concentration only drops with the addition of the dilute tributary rivers downstream.

The ${ }^{234} \mathrm{U}{ }^{238} \mathrm{U}$ activity ratios are plotted along side of the $\mathrm{U}$ concentrations in Figure 20d. Note that the activity ratios show essentially no change for the entire range of $U$ concentrations. Recall from previous studies in the Platte River that with increasing U concentration there was a concomitant increase in the activity ratio due to increasing groundwater input, whereas during runoff, the activity ratio approached unity reflecting the uranium source material (Snow and Spalding, 1994). In the San Joaquin River case, the lack of any appreciable change in the activity ratio over a large concentration range suggests that a single source contributes dissolved uranium to the river discharge. Furthermore, this single source must increase in U concentration along the San Joaquin drainage, reaching a maximum on the west-side of the valley $\sim 110$ miles downstream. Since the activity ratios are appreciably above 1.0 , it is likely that the uranium is derived from a natural source rather than an artificial one. It is also likely soils in the San Joaquin Valley are naturally high in oxidized forms of $\mathrm{U}$, and the concentration increases towards the valley center where natural wetlands once dominated and possibly accumulated trace metals. 
The ${ }^{36} \mathrm{Cl} / \mathrm{Cl}$ ratios are also presented along side of the $\mathrm{Cl}$ concentrations in Figure 20c. They show a dramatic decrease from essentially modern fallout values $\left(>1000 \times 10^{-15}\right.$; e.g. Bentley et al., 1986) for low $\mathrm{Cl}$ concentrations, to values approaching a near ${ }^{36} \mathrm{Cl}$-absent source $\left(<10 \times 10^{-15} ;\right.$ e.g. sea salt $)$ at higher $\mathrm{Cl}$ concentration. Such a trend is consistent with dissolution of natural salt sources. Their probable accumulation in the center of the San Joaquin Valley were likely related to evaporation in natural floodplains with limited outlets.

\section{Temporal Variation in Water Quality and Isotopic Abundance}

Comparison of isotopic data and water quality measurements between different seasons and flow conditions in the San Joaquin River suggest a potential tracer approach for non-point source runoff (Figs. $21 \mathrm{abcd}$ ). For example, $\delta^{18} \mathrm{O}$ values of river water vary significantly during storm flow versus that of baseflow (Fig. 21a). Because of the elevation effect in $\delta^{18} \mathrm{O}$ of precipitation, low elevation rainfall will have distinctly higher values than precipitation in the mountains that collect in reservoirs. The high $\delta^{18} \mathrm{O}$ value seen in the lower San Joaquin River on $1 / 14 / 98$ (-8.7 per mil) was collected a few hours after a large storm produced substantial rainfall and runoff $(\sim 6200 \mathrm{cfs})$ in the San Joaquin Valley, and before any reservoir release occurred upstream. Note that this river flow also had the high DOC concentration of $9.0 \mathrm{mg} / \mathrm{L}$ (Fig. 21b). Three weeks later, during another precipitation event, substantial flow was recorded from reservoir release in the upper San Joaquin River and major tributaries, as noted by the substantially higher discharge rate $(\sim 24,000 \mathrm{cfs})$. The $\delta^{18} \mathrm{O}$ value of this water was again low $(-10.4$ per mil), similar to baseflow. Note for this sample the DOC was somewhat lower at $6.6 \mathrm{mg} / \mathrm{L}$. Therefore, the 
$\delta^{18} \mathrm{O}$ is useful as a tracer of surface runoff from local versus regional sources and showed distinct water quality differences.

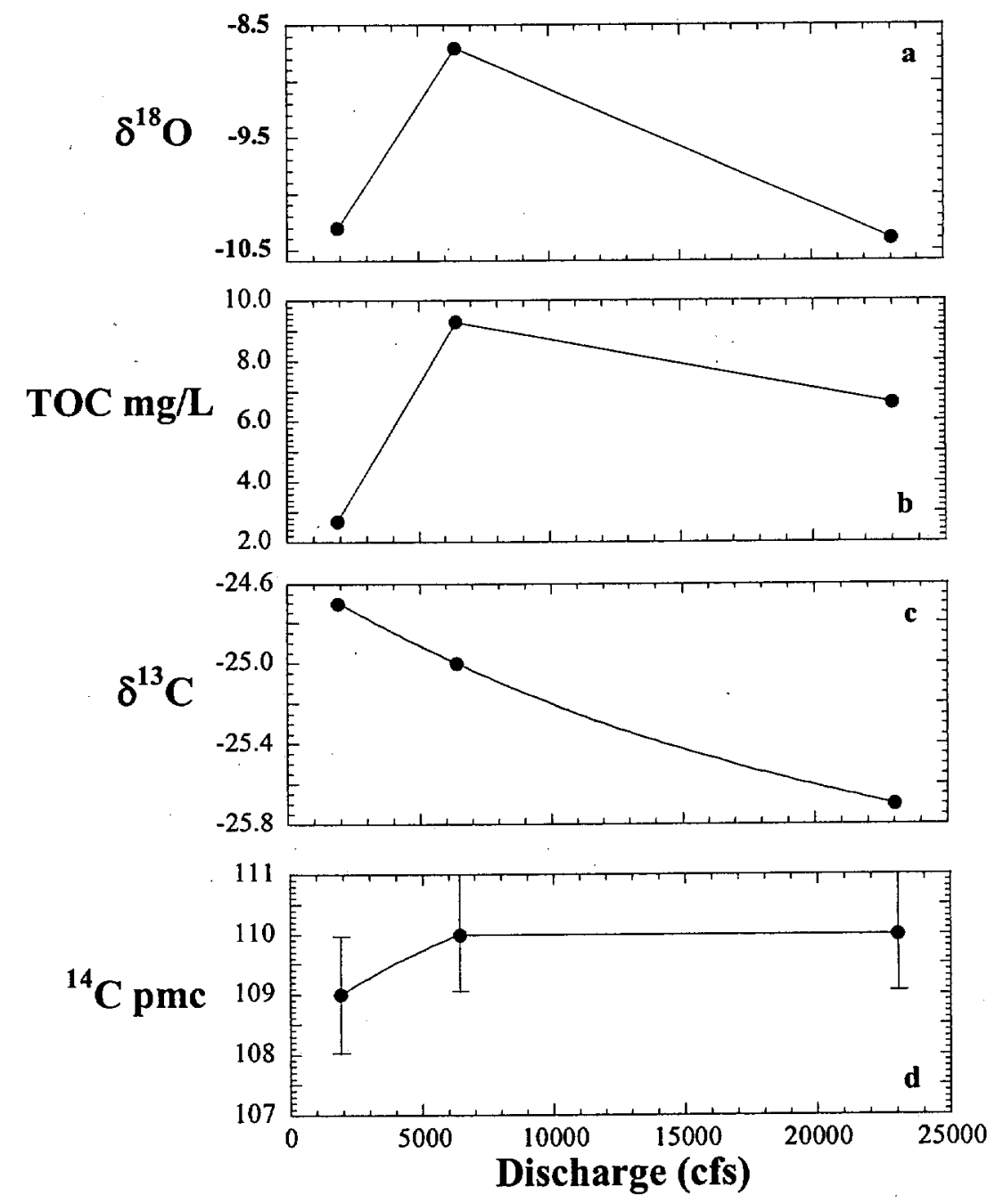

Figure 21 abcd. The $\delta^{18} \mathrm{O}$ value was significantly higher during runoff $(\sim 6200 \mathrm{cfs})$, where only low elevations contributed a high DOC discharge and reservoirs were not releasing large flows. The subsequent high runoff event $(\sim 24,000 \mathrm{cfs})$ comprised mostly reservoir releases that resulted in a low $\delta^{18} \mathrm{O}$ value and somewhat lower DOC. The $\delta^{13} \mathrm{C}_{\mathrm{DOC}}$ decreased by about 1.0 per mil and was likely related to contribution of upper watershed $\mathrm{DOC}$ from alpine vegetation. This possible change in source was not notable in ${ }^{14} \mathrm{C}_{\mathrm{DOC}}$.

Also measured for these samples was the $\delta^{13} \mathrm{C}_{\mathrm{DOC}}$ and the ${ }^{14} \mathrm{C}_{\mathrm{DOC}}$ (Fig. 21cd). Between baseflow at $\sim 2000 \mathrm{cfs}$ in the late summer and high runoff at $\sim 24,000 \mathrm{cfs}$ in February, the $\delta^{13} \mathrm{C}_{\mathrm{DOC}}$ decreased approximately 1.0 per mil. The direction of this change is consistent 
with seasonal change in the Missouri River (Fig. 15). It is possible that the change in $\delta^{13} \mathrm{C}_{\mathrm{DOC}}$ in the San Joaquin River is related to transport of DOC from the upper watershed during the high runoff. However, comparison of the ${ }^{14} \mathrm{C}_{\mathrm{DOC}}$ in these samples shows no credible variation within analytical uncertainty, averaging around 109pmc. It is likely that the source of organic matter has similar turnover both in the upper and lower watershed, whereas a slight difference in $\delta^{13} \mathrm{C}$ of the $\mathrm{DOC}$ is all that distinguishes their two sources isotopically. Of further note, DOC from the San Joaquin River collected during high flow in January, 1997 (Table 4) was fractionated for humic substances and the ${ }^{14} \mathrm{C}$ was measured (not in Table 4 but plotted in Fig. 13). The fulvic acid fraction of this DOC had a ${ }^{14} \mathrm{C}$ of $103 \mathrm{pmc}$, while the humic acid fraction was $89 \mathrm{pmc}$. The modern ${ }^{14} \mathrm{C}$ value for the fulvic acid suggests a carbon source with relatively high productivity, similar to a deciduous forest.

One last observation to make is in regards to the low-level methyl-tert-butylether (MTBE) measurements on river water. Samples were collected mostly during the wintertime or late spring. In all cases, the MTBE was readily detected at levels close to 80 parts per trillion for near-pristine discharges like Corral Hollow Creek, or at low part per billion in the case of the Mokelumne and Sacramento Rivers in May, 1998 (Table 4). The high levels in surface water are due to non-point contribution from the automobile exhaust, and because of MTBE's high solubility, it is readily dissolved in river water at ten of part per trillion. Higher concentrations are likely due to exhaust from motorpowered recreational vehicles in reservoirs. 


\section{Findings, Conclusions, and Recommendations to Utilities}

This study concludes that water quality data generated by utilities is under-interpreted in the context of understanding watershed processes. For example, the City of St. Louis depends solely on the Missouri River for drinking water, but due to large variability in discharge and runoff sources, they are faced with TOC concentrations that vary nearly a factor of three within a single season. Until this study, the relationship between discharge and concentration had not been constrained. However, the TOC can be linearized against the fractional amount of downstream discharge (derived from within the State of Missouri) and divided into two principle sources. This correlation relates directly to differences in land use and climate between the upstream and downstream portions of the river basin.

In addition to using utility water quality data to better understand non-point source pollutants, non-regulatory type data can be generated to enhance observational knowledge. Data such as isotopic measurements of water and dissolved constituents can provide indirect evidence for sources and the processes governing the occurrence and concentration of non-point source pollutants. For example, using isotope measurements of carbon-13 on TOC in the Missouri River, we were able to distinguish carbon originating from algae photosynthesis versus that generated from land plant material. Their relative proportions correlated with season and water temperature. We also found that the carbon-14 abundance of TOC decreased with increasing humic substances, indicating that at various times TOC comprises older sources of carbon. Humic material also preferentially forms tri-halomethanes during chlorination, relative to the remaining portion of TOC. The carbon-14 abundance of humic substances showed a strong inverse 
correlation to electrical conductivity. This relationship provided a basis to delineate the geographic source of the TOC. In addition, the carbon-14 of humic isolates from several rivers located in the western hemisphere, representing different climates, positively correlated with mean annual precipitation, indicating a strong relationship between solublization rates of soil carbon and regional climate. This may provide a predictive basis for humic sources in watersheds similar to the Missouri River.

The oxygen-18 abundance of surface water from large rivers in Missouri and California can delineate geographic sources of runoff from various parts of the watershed. The oxygen-18 correlation to water quality parameters was shown to verify geographic sources of TOC and dissolved salts in the Missouri River. However, during storm flows or anomalous events such as El Nino, the oxygen-18 shows strong perturbations from long-term averages. Nevertheless, in large California rivers significant changes in oxygen-18 abundance during storm runoff can delineate local runoff sources versus regional ones. This measurement may be useful for predicting storm water quality related to different geographic land uses.

It is recommended that for utilities relying on water from large rivers that they begin to independently or cooperatively assess water quality data from other sources in the watershed and integrated into their own. The data assessment should recognize the substantial influence that regional climate and its intra-variability within the basin has on water quality. Delineating natural versus man-made water quality effects in large rivers may be further enhanced by interdisciplinary approaches, using expertise in geology, geochemistry, ecology, and biogeochemistry. This likely will provide a framework for 
"sound science" in watershed management. It would be the responsibility of the utility to educate this expertise in the relevance of their research to water quality concerns.

Much of the isotopic results shown in this report require expensive and timeconsuming work. For a utility to undertake this kind of work themselves would require contracting with university or research laboratory scientists. However, the $\delta^{18} \mathrm{O}$ measurement has become cheap ( $\$ 10-\$ 20$ each), rapid (24hrs), and routine, and it is highly recommended that they become part of daily to weekly analysis. The data generated at that frequency would allow delineation of different source water contributing to plant intake and its correlation to water quality. In addition, the source of storm water runoff and its water quality could also be distinguished by this frequency of data. The available literature on $\delta^{18} \mathrm{O}$ in the hydrologic environment is abundant, and a motivated person with a bachelor's degree in chemistry, engineering, or geology could easily gain expertise in its use. 


\section{References}

Aiken, G.R. and Malcolm, R.L., 1987, Molecular weight of aquatic fulvic acids by vapor pressure osmometry. Geochim. Cosmochim. Acta, 51, 2177-2184.

Aiken, G.R., Mcknight, D.M., Thorn, K.A., Thurman, E.M., 1992, Isolation of hydrophilic organic acids from water using nonionic macroporous resins. Org. Geochem., 18, 567-573.

Amy, G.L., Tompson, J.M., Tan, L., and others, 1990, Evaluation of THM precursor contributions from agricultural drains. Jour. AWWA, Jan, 57-64

Aravena, R. and Suzuki, O., 1990, Isotopic evolution of river water in the northern Chile reion. Water. Resour. Res., 26, 2887-2895.

Artinger, R., Buckau, G., Kim, J.I., and others, 1996, Influence of sedimentary organic matter on dissolved fulvic acids in groundwater. In Isotope in Water Resources Management, International Atomic Energy Agency, Vienna, 1995, pp. 57-72.

Aucour, A., Sheppard, S.M.F., Guyomar, O., Wattelet, J., 1999, Use of ${ }^{13} \mathrm{C}$ to trace origin and cycling of inorganic carbon in the Rhone river system. Chem. Geol., 159, 87-105.

Barnes, C.J. and Allison, G.B., 1988, Tracing of water movement in the unsaturated zone using stable isotopes of hydrogen and oxygen. J. Hydrol., 100, 143-176.

Barth, J.A.C., Veizer, J., Mayer, B., 1998, Origin of particulate organic carbon in the upper St. Lawrence: isotopic constraints. Earth and Planetary Science Letters, 162, 111-121.

Bassett, R.L., Buszka, P.M., Davidson, G.R., Damarais Chong-Diaz, 1995, Identification of groundwater solute sources using boron isotopic composition. Environ. Sci. Technol., 29, 2915.

Bentley, H.W., Phillips, F.M., Davis, S.N., Habermehl, M.A., Airey, P.L., Calf, G.E., Elmore, D., Gove, H.E., Torgersen, T., 1986, Chlorine-36 dating of very old groundwater: 1. The Great Artesian Basin, Australia. Water Resour. Res., 22, p. 19912001.

Bird, M.I., Giresse, P., Ngos, S., 1998, A seasonal cycle in the carbon-isotope composition of organic carbon in the Sanaga River, Cameroon. Limnol. Oceanogr., 43, 143-146

Blum, J.D., Erel, Y., Brown, K., 1994, ${ }^{87} \mathrm{Sr} /{ }^{86} \mathrm{Sr}$ ratios of Sierra Nevada stream water: Implications for relative mineral weathering rates. Geochim. Cosmochim. Acta, 58, 5019-5025.

Brinson, M.M., 1976, Organic matter losses from four watersheds in the humid tropics. Limnol. Oceanogr., 21, 572-582.

Buhl, D., Neuser, R.D., Richter, D.K., and others, 1991, Nature and nuture: Environmental isotope story of the Rhine River. Naturwissenschaften, 78, 337-346.

Bullen, T.D., Krabbenhoft, D.P., Kendall, C., 1996, Kinetic and mineralogical controls on the evolution of groundwater chemistry and ${ }^{87} \mathrm{Sr} /{ }^{86} \mathrm{Sr}$ in a sandy silicate aquifer, northern Wisconsin. Geochim. Cosmochim. Acta, 60, 1807-1821.

Bullen, T.D., White, A.F., Blum, A.E., and others, 1997, Chemical weathering of a soil chronosequence on granitoid alluvium: II. Mineralogical and isotopic constraints on the behavior of Sr. Geochim. Cosmochim. Acta, 61, 291-306. 
Bullen, T.D. and Kendall, C., 1998, Tracing of weathering reactions and water flowpaths: a multi-isotope approach. In Kendall, C. and McDonnell, J.J. eds. Isotope Tracers in Catchment Hydrology. Elsevier: Amsterdam, 611-646.

Burke, W.H., Denison, R.E., Hetherington, E.A., and others, 1982, Variation of seawater ${ }^{87} \mathrm{Sr}{ }^{86} \mathrm{Sr}$ throughout Phanerozoic time. Geol., 10, 516-519.

Chesterikoff, A., Garbian, B., Billen, G., Poulin, M., 1992, Inorganic nitrogen dynamics in the River Seine downstream from Paris (France). Biogeochemistry, 17, 147-164.

Coplen, T.B. and Kendall, C., 2000, Stable hydrogen and oxygen isotope ratios for selected sites of the US Geologic Survey's NASQAN benchmark surface water networks. US Geologic Survey Open File Rep. 00-160, 424pp.

Craig H., 1961, Isotopic variations in meteoric waters. Science 133, 1702-1703.

Craig H., Gordon L.I., Horibe Y., 1963, Isotopic exchange effects in the evaporation of water. J. Geophys. Res. 68, 5079-5087.

Craig H. and Gordon L.I., 1965, Deuterium and oxygen-18 variations in the ocean and the marine atmosphere, in Third Spoleto Nuclear Geology Conference on Paleotemperatures and Isotopic Oceanography, Proceedings of the Third Spoleto Conference, Spoleto, Italy, July, 1965, edited by E. Tongiorgi, E., 378 pp.

Criss, R.E. and Davisson, M.L., 1996, Isotopic imaging of surface water/groundwater interactions, Sacramento Valley, California. J. Hydrol.178, 205-222.

Criss, R.E., 1999, Principles of Stable Isotope Distribution, Oxford University Press, New York.

Criss, R.E., Davisson, M.L., and Kopp, J.W., 2001, Nonpoint sources in the lower Missouri River. Jour. AWWA, 93, 112-122.

Cronan, C.S., Piampiano, J.T., Patterson, H.H., Influence of landuse and hydrology on exports of carbon and nitrogen in a Maine river basin. J. Environ. Qual., 28, 953-961.

Dansgaard W., 1964, Stable isotopes in precipitation. Tellus XVI 4, 436-468.

Davisson, M.L. and Criss, R.E., 1993, Stable isotope imaging of a dynamic groundwater system in the southwestern Sacramento Valley, California (USA). J. Hydrol. v. 144, pp. 213-246.

Davisson, M.L., Presser, T.S., Criss, R.E., 1994, Geochemistry of tectonically expelled fluids from the northern Coast Ranges, Rumsey Hills, California. Geochim.Cosmochim Acta, 58, 1687-1699.

Davisson, M.L., Velsko, C.A., 1994, Rapid extraction of dissolved inorganic carbon from small volumes of natural waters for ${ }^{14} \mathrm{C}$ determination by accelerator mass spectrometry. Lawrence Livermore National Laboratory UCRL-JC-119176, 23 pp.

Deines, P., 1980, The isotopic composition of reduced carbon. in Handbook of Environmental Isotope Geochemistry. Vol. 1, edited by P. Fritz and J. Ch. Fontes, J. Ch., 329-406.

DeNiro, M.J. and Epstein, S., 1979, Relationship between the oxygen isotope ratios of terrestrial plant cellulose, carbon dioxide, and water. Science, 204, 51-53.

Deverel, S.J. and Gallenthine, S.K., 1989, Relation of salinity and selenium in shallow groundwater to hydrologic and geochemical processes, western San Joaquin Valley, California. J. Hydrol. 109, 125-149.

Ding, W.H., Fujita, Y., Aeschimann, R.; Reinhard, M., 1996, Identification of organic residues in tertiary effluents by GC/EI-MS, GC/CI-MS and GC/TSQ Fresenius Journal Of Analytical Chemistry, 1996 Jan, V354 N1:48-55. 
Douglas, G.B., Gray, C.M., Hart, B.T., Beckett, R., 1995, A strontium isotopic investigation of the origin of suspended particulate matter (SPM) in the MurrayDarling River system, Australia. Geochim. Cosmochim. Acta, 59, 3799-3815.

Driscoll, C.T., Likens, G.E., Hedin, L.O., Eaton, J.S., Bormann, F.H., 1989, Changes in chemistry of surface waters. Environ. Sci. Technol., 23, 137.

Dubrovsky, N.M., Kratzer, C.R., Brown, L.R., and others, 1998, Water Quality in the San Joaquin-Tulare Basins, California. US Geological Survey Circular 1159, 43pp.

Duff, M.C., Amrhein, C., Bradford, G., 1997a, Nature of uranium contamination in the agricultural drainage water evaporation ponds of the San Joaquin Valley, California, USA. Can. J. Soil Sci., 77, 459-467.

Duff, M.C., Amrhein, C., Bertsch, P.M., Hunter, D.B., 1997b, The chemistry of uranium in evaporation pond sediment in the San Joaquin Valley, California, USA, using X-ray fluorescence and XANES techniques. Geochim. Cosmochim. Acta, 61, 73-81.

Durka, W., Schulze, E., Gebauer, G., Voerkelius, S., 1994, Effects of forest decline on the uptake and leaching of deposited nitrate determined from ${ }^{15} \mathrm{~N}$ and ${ }^{18} \mathrm{O}$ measurements. Nature, 372, 765-767.

Elmore, D., et al., 1979, Analysis of ${ }^{36} \mathrm{Cl}$ in environmental water samples using an electrostatic accelerator. Nature, 277, p. 22-25.

Epstein S., Mayeda T., 1953, Variation of ${ }^{18} \mathrm{O}$ content of waters from natural sources. Geochimica et Cosmochimica Acta, 4, pp. 213-224.

Epstein, S., Tompson, P., Yapp, C.J., 1977, Oygen and hydrogen isotopic ratios in plant cellulsoe. Science, 198, 1209-1215.

Faure, G. 1986, Principles of Isotope Geology. John Wiley and Sons: New York, 464pp.

Fiebig, D.M., Lock, M.A., Neal, C., 1990, Soil water in the riparian zone as a source of carbon for headwater stream. J. Hydrol. 116, 217-237.

Frederickson, G.C. and Criss, R.E., 1999, Isotope hydrology and time constants of the unimpounded Meramec River basin, Missouri. Chem. Geol., 157, 303-317.

Friedman, I. Redfield, A.C., Schoen, B. Harris, J., 1964, The variation of the deuterium content of natural waters in the hydrologic cycle. Rev. Geophys., 2, 177-224.

Friedman, I. and Smith, G.I., 1972, Deuterium content of snow as an index to winter climate in the Sierra Nevada Area. Science, 176, 790-793.

Funk, J.L. and Robinson, J.W., 1974, Changes in the channel of the lower Missouri River and effects on fish and wildlife. Missouri Department of Conservation, Aquatic Series No. 11, Jefferson City, Missouri.

Garrels, R.M. and Mackenzie, F.T., 1971, Evolution of Sedimentary Rocks. W.W. Norton \& Co., Inc.: New York, 397pp.

Gibbs, R.J., 1970, Mechanisms controlling world water chemistry. Science, 170:1088.

Goñi, M.A., Ruttenberg, K.C., Eglinton, T.I., 1998, A reassessment of the sources and importance of land-derived organic matter in the surface sediments from the Gulf of Mexico. Geochim. Cosmochim. Acta, 62, 3055-3075.

Goolsby, D.A., Battaglin, W.A., Aulenbach, B.T., Hoopper, R.P., 2000, Nitrogen fluxes and sources in the Mississippi River basin. Science Total Environ., 248, 75-86.

Grosbois, C., Negrel, Ph., Fouillac, C., Grimund, D., 2000, Dissolved load of the Loire River: chemical and isotopic characterization. Chem. Geol., 170,179-201.

Harris, T., 1991, Death in the Marsh. Island Press: Washington, D.C. 
Harrision, K.G., Broecker, W.S., Bonani, G., 1993, The effect of changing land use on soil carbon. Science, 262, 725-726.

Hauck, H.S.; Huber, L.G.; \& Nagel, C.D., 1997, Water resources data, Missouri, Water Year 1997. U.S. Geological Survey Water-Data Report MO-97-1.

Hauck, R.D., Bremner, J.M., Broadbent, F.E., and others, 1972, Use of variations in natural nitrogen isotope abundance for environmental studies: A questionable approach. Science, 177, 453-454.

Hayes, M.H.B. and Swift, R.S., 1978, The chemistry of soil organic colloids. In Greenland, D.J. and Hayes, M.H.B. (eds) The Chemistry of Soil Constituents. John Wiley and Sons: New York, pp. 179-320.

Heaton, T.H.E., 1986, Isotopic studies of nitrogen pollution in the hydrosphere and atmosphere: a review. Chem. Geol., 59, 87-102.

Hedges, J.I., Ertel, J.R., Quay, P.D., et al., 1986, Organic carbon-14 in the Amazon River system. Science, 231, 1129-1131.

Heidmann, P.B., and , H.W., 1992, Studies of soil organic matter dynamics using natural carbon isotopes. Science Total Environ., 117/118, 305-312.

Hinrichs, J; Schnetger, B., 1999, A fast method for the simultaneous determination of Th230, U-234 and U-235 with isotope dilution sector field ICP-MS. Analyst, 124, 927932.

Hitchon, B. and Krouse, H.R., 1972, Hydrogeochemistry of the surface waters of the Mackenzie River drainage basin, Canada III. Stable isotopes of oxygen, carbon, and suphur. Geochim. Cosmochim. Acta, 36:1337-1357.

Hodell, D.A. and Schelske, C.L., 1998, Production, sedimentation, and isotopic composition of organic matter in Lake Ontario. Limnol. Oceanogr., 43, 200-214.

Hübner, H., 1986, Isotope effects of nitrogen in the soil and biosphere. in Handbook of Environmental Isotope Geochemistry. Vol. 2, edited by P. Fritz and J. Ch. Fontes, J. Ch., 361-425.

Homyk, A. and Jeffery, H.G., 1967, Surface water, in Mineral and Water Resources of Missouri, Missouri Geological Survey, $2^{\text {nd }}$ ser., 43, 258.

Ii, H. Hirata, T., Matsuo, H. Nishikawa, M., Tase, N., 1997, Surface water chemistry, particularly concentrations of $\mathrm{NO}_{3}{ }^{-}$and $\mathrm{DO}$ and $\delta^{15} \mathrm{~N}$ values, near a tea plantation in Kyusha, Japan. J. Hydrol., 202, 341-352.

Ingraham, N.L., and Taylor, B.E., 1991, Light stable isotope systematics of large-scale hydrologic regimes in California and Nevada, Water Resour. Res., 27, 77-90.

Ingri, J., Torssander, P., Andersson, P.S., and others, 1997, Hydrogeochemistry of sulfur isotopes in the Kalix River catchment, northern Sweden. Appl. Geochem., 12, 483496.

Ivanovich, M. and Harmon, R.S., eds., 1982, Uranium Series Disequilibrium: Applications to Environmental Problems. Clarendon Press: Oxford.

Ivanovich M., Frohlich K., Hendry M.J., 1991, Dating very old groundwater, Milk River Aquifer, Alberta, Canada study. Applied Geochemistry, 6, 367-367.

Izenberg, N.R., 1996, Assessment of damage from the 1993 floods on the Missouri River floodplain using LANDSAT, SPOT, SIR-C, TOPSAR, and field data. Unpub. Ph.D. dissertation, Washington University. 
Kalbitz, K., Geyer, S., Gehre, M., 2000, Land use impacts on the isotopic signature $\left({ }^{13} \mathrm{C}\right.$, ${ }^{14} \mathrm{C},{ }^{15} \mathrm{~N}$ ) of water-soluble fulvic acids in a German fen area. Soil Sci., 165, 728-736.

Karim, A. and Veizer, J., 2000, Weathering processes in the Indus River Basin: implications from riverine carbon, sulfur, oxygen, and strontium isotopes. Chem. Geol., 170, 153-177.

Keeling, C.D., Bacastow, R.B., Carter, A.F., and others, A three-dimensional model of atmospheric $\mathrm{CO}_{2}$ transport based on observed winds: 1 . Analysis of observational data. Geophys. Monogr. No. 55, Am. Geophys. Union, Washington DC, 165-236.

Kendall, C., 1998, Tracing nitrogen sources and cycling in catchments. In Kendall, C. and McDonnell, J.J. eds. Isotope Tracers in Catchment Hydrology. Elsevier: Amsterdam, 519-576.

Kendall, C., Battaglin, W.A., Cabana, G., and others, 1999, Isotopic tracing of nitrogen sources and cycling in the Mississippi River Basin. US Geoloical Survey Water Resources Investigation Report 99-4018B.

Koester, C., Davisson, M.L., Moran, J.E., 1998, Measurement of methyl-tert-butyl-ether (MTBE) in raw drinking water. AWWA Water Quality Techol. Conf. Nov, 1998, San Diego, also Lawrence Livermore National Laboratory UCRL-JC-131894, 9pp.

Kohl, D.H., Shearer, G.B., Commoner, B., 1971, Fertilizer nitrogen: Contribution to nitrate in surface water in a corn belt watershed. Science, 174, 1331-1334.

Komor, S.C., 1997, Boron contents and isotopic compositions of hog manure, selected fertilizers, and water in Minnesota. J. Environ. Qual., 26, 1212-1222.

Kreitler, C.W. and Jones, D.C., 1975, Natural soil nitrate: the cause of nitrate contamination of groundwater in Runnels County, Texas. Groundwater, 13, 53-61.

Kreitler, C.W. and Browning, L.A., 1983, Nitrogen isotope analysis of groundwater nitrate in carbonate aquifers: natrual sources versus human pollution. J. Hydrol., 61285-301.

Kuivila, K.M. and Foe, C.G., 1995, Concentrations, transport and biological effects of dormant spray pesticides in the San Francisco estuary, California. Environ. Toxicol. Chem., 14, 1141-1150.

Lambs, L., 2000, Correlation of conductivity and stable isotope ${ }^{18} \mathrm{O}$ for the assessment of water origin in river system. Chem. Geol., 164, 161-170.

Larson, R. A., and Weber, E. J., 1994, Reactions with Disinfectants, Chapter 4 in Reaction Mechanisms in Environmental Organic Chemistry, Lewis Publishers, Ann Arbor, MI. pp. 275-341.

Lawrence, J.R., Gedzelman, S.D., White, J.W.C., et al., 1981, Storm trajectories in eastern US D/H isotopic composition of precipitation. Nature, 296, 638-640.

Lawrence, G.B., Goolsby, D.A., Battaglin, W.A., 1999, Atmospheric deposition of nitrogen in the the Mississippi River Basin. US Geoloical Survey Water Resources Investigation Report 99-4018B.

Laws, E.A., 1993, Aquatic Pollution. John Wiley and Sons, Inc.: New York, 611pp.

Leenheer, J. A., 1994, Chemistry of dissolved organic matter in rivers, lakes, and reservoirs: In Environmental Chemistry of Lakes and Reservoirs (Baker, L. A., Ed.) Advances in Chemistry Series No. 237, American Chemical Society, Washington, D.C., pp. 195-222.

Leenheer, J.A.; Croue, J.-P.; Benjamin, M.; Korshin, G.V.; Hwang, C.J.; Bruchet, A.; Aiken, G.R, 2000. Comprehensive isolation of natural organic matter from water for 
spectral characterizations and reactivity testing. In Barrett, S., Ed. Natural Organic Matter and Disinfection By-Products. ACS Symposium Series _, Wash. D.C., (in press).

Létolle, R., 1980, Nitrogen-15 in the natural environment. in Handbook of Environmental Isotope Geochemistry. Vol. 1, edited by P. Fritz and J. Ch. Fontes, J. Ch., 407-433.

Lindau, C.W., Delaune, R.D., Patrick, W.H., Lambremont, E.N., 1989, Assessment of stable nitrogen isotopes in fingerprinting surface water inorganic nitroogen sources. Water, Air, Soil, Pollution, 48, 489-496.

Longinelli, A. and Edmond, J.M., 1983, Isotope geochemistry of the Amazon basin: A reconnaissance. J. Geophys. Res., 88, 3703-3717.

Lytle, C.R. and Perdue, E.M., 1981, Free, proteinaceous, and humic-bound amino acids in river water containing high concentrations of aquatic humus. Environ. Sci. Technol., 15, 224-228.

Mac Kenzie, W.R., Hoxie, N.J., Proctor, M.E., and others, 1994, A massive outbreak in Milwaukee of cryptosporidium infection transmitted through the public water supply. New Eng. J. Med., 331, 161-167.

Malakoff, D., 1998, Death by suffocation in the Gulf of Mexico. Science, 281, 190.

Malcolm, R.L., 1985, Geochemistry of stream fulvic and humic substances. In (Aiken, G.R., McKnight, D.M., Wershaw, R.L., eds) Humic Substances in Soil, Sediment, and Water. John Wiley and Sons New York, pp. 181-210.

Mann, C.J. and Wetzel, R.G., 1995, Dissolved organic carbon and its utilization in a riverine wetland ecosystem. Biogeochemistry, 31, 99-120.

Mariotti, A., Létolle, R., Blavoux, B., Chassaing, B., 1975, Determination par les teneurs naturelles en ${ }^{15} \mathrm{~N}$ de l'origine des nitrates: résultats préliminaires sur le bassin de Melarchez (Seine et Marne). C.R. Acad. Sci., Paris, 280, 423-426.

McDowell, W.H. and Wood, T., 1984, Podzolization: Soil processes control dissolved organic carbon concentrations in stream water. Soil Sci., 137, 23-32.

McMahon, P.B. and Bohlke, J.K., 1996, Denitrification and mixing in a stream-aquifer system: effects on nitrate loading to surface water. J. Hydrol. 186, 105-128.

McNichol, A.P., Jones, G.A., Hutton, D.L., Gagnon, A.R., and others, 1994, The rapid preparation of seawater sigma- $\mathrm{CO}_{2}$ for radiocarbon analysis at The National Ocean Sciences AMS Facility. Radiocarbon, 36, 237-246.

Meybeck, M., Chapman, D., Helmer, R., 1989Global Freshwater Quality, A First Assessment. World Health Organization and United Nations Environment Programme, Basil Blackwell Ltd., Cambridge, MA.

Moldan, B. and Èern, J., 1994, Small catchment research, in Moldan, B. and Èern, J., eds. Scope 51, Biogeochemistry of Small Catchments, A Tool for Environmental Research, John Wiley and Sons: New York.

Mook, W.G., 1980, Carbon-14 in hydrogeological studies, in Handbook of Environmental Isotope Geochemistry. Vol. 1, edited by P. Fritz and J. Ch. Fontes, J. Ch., 49-74,.

Mook, W.G. and Tan, F.C., 1991, Stable carbon isotopes in rivers and estuaries. In Degens, E.T., Kempe, S., Richey, J.E., eds. SCOPE 42 Biogeochemistry of Major World Rivers. John Wiley and Sons, Inc.: New York, 245-264.

Mulholland, P.J. and Kuenzler, E.J., 1979, Organic carbon export from upland and forested wetland watersheds. Limnol. Oceanogr., 24, 960-966. 
Munster, U. and Chrost, R.J., 1990, Origin, composition, and microbial utilization of dissolved organic matter. In Overback, J. and Chrost, R.J. eds. Aquatic Microbial Ecology, Springer-Verlag: New York, 8-46.

Nadelhoffer, K.J. and Fry, B., 1988, Controls on natural nitrogen-15 and carbon -13 abundances in forest soil organic matter. Soil Sci. Soc. Am. J., 52, 1633-1640.

National Research Council, 1999, New Strategies for America's Watersheds. National Acadamy Press: Washington, D.C., 328pp.

National Science and Technology Council, 2000, Hypoxia in the Gulf of Mexico, Progress towards the completion of an Integrated Assessment. http://www.nos.noaa.gov/Products/pubs_hypox.html

Nelson, P.N., Baldock, J.A., Oades, J.M., 1993, Concentration and composition of dissolved organic carbon in streams in realtion to the catchment soil properties. Biogeochem., 19, 27-50.

Novotny, V. and Chesters, G., 1981, Handbook of Nonpoint Pollution. Van Nostrand Reinhold Co.: New York, 555pp.

Osmond, J.K. and Cowart, J.B., 1982, Groundwater. in Ivanovich, M. and Harmon, R.S., eds. Uranium Series Disequilibrium: Applications to Environmental Problems. Clarendon Press: Oxford. p. 202-245.

Parks, S.J. and Baker, L.A., 1997, Sources and transport of organic carbon in an Arizona River-Reservoir system. Wat. Res., 31, 1751-1759.

Patrick, R., 1998, Rivers of the United States. IV. The Mississippi River and its Tributaies North of Saint Louis. John Wiley \& Sons, New York .

Palmer, M.R. and Edmond, J.M., 1992, Controls over the strontium isotope composition of river water. Geochim. Cosmochim. Acta, 56, 2099-2111.

Palmer, M.R. and Edmond, J.M., 1993, Uranium in river water. Geochim. Cosmochim. Acta, 57, 4947-4955.

Payne, B.R., Quijano, L., Lattore, D.C., 1979, Environmental isotopes in the study of the origins of salinity of groundwater in the Mexicali Valley. $J$. Hydrol., 41, 201-215.

Peierls, B.L., Caraco, N.F., Pace, M.L., Cole, J.J., 1991, Human influence on river nitrogen. Nature, 350, 386-387.

Pionke, H.B., Gburek, W.J., Folmar, G.J., 1993, Quantifying stormflow components in a Pennsylvania water shed when ${ }^{18} \mathrm{O}$ input and storm conditions vary. J. Hydrol., 148, 169-187.

Plater, A.J., Ivanovich, M., Dugdale, R.E., Uranium series disequilibrium in river sediments and water: the significance of anomalous activity ratios. Appl. Geochem., 7, 101-110.

Porcelli, D., Andersson, P.S., Wasserburg, G.J., Ingri, J., Baskaran, M., 1997, The importance of colloids and mires for the transport of uranium isotopes through the Kalix River watershed and Baltic Sea. Geochim. Cosmochim. Acta, 61, 4095-4113.

Presser, T.S. and Swain, W.C., 1990, Geochemical evidence for Se mobilization by the weathering of pyritic shale, San Joaquin Valley, California, USA. Applied Geochemistry, 5, 703-717.

Quay, P.D., Wilbur, D.O., Richey, J.E., et al., 1992, Carbon cycling in the Amazon River: Implications from the ${ }^{13} \mathrm{C}$ compositions of particles and solutes. Limnol. Oceanogr., 37, 857-871. 
Ramesh, R. and Sarin, M.M., 1992, Stable isotope study of the Ganga (Ganges) river system. J. Hydol., 139, 49-62.

Reeder, S.W. Hitchon, B. and Levinson, A.A., 1972, Hydrogeochemistry of the surface waters of the Mackenzie River drainage basin, Canada I. Factors controlling inorganic composition. Geochim. Cosmochim. Acta, 36, 825.

Robinson, B.W. and Botrell, S.H., 1997, Discrimination of sulfur sources in pristine and polluted New Zealand river catchments using stable isotopes. Appl. Geoch., 12, 305319.

Rodriguez-Alvarez, M.J. and Sanchez, F., 1999, The transfer of uranium from sediment to water along Jucar River, Spain. J. Radioanal. Nuc. Chem., 242, 297-307.

Rook, J.J., 1977, Chlorination reactions of fulvic acids in natural waters. Environmental Science and Technology, 11, 478-482.

Rose, T.P., Davisson, M.L., Criss, R.E., 1996, Isotope hydrology of voluminous cold springs in fractured rock from an active volcanic region, northeastern California. $J$. Hydrol., 179, 207-236.

Schiff, S.L., Aravena, R., Trumbore, S.E., Dillon, P.J., 1990, Dissolved organic carbon cycling in forested watersheds: a carbon isotope approach. Water Resour. Res., 26, 2949-2957.

Schiff, SL; Aravena, R; Trumbore, SE; Hinton, MJ; and others., 1997, Export of DOC from forested catchments on the Precambrian Shield of Central Ontario: Clues from C13 and C-14. Biogeochemistry, 36, 43-65.

Schlesinger, W.H., 1997, Biogeochemistry: An Analysis of Global Change. Academic Press: San Diego, 588p.

Semhi, K., Clauer, N., Probst, J.L., 2000, Strontium isotope compositions of river waters as records of lithology-dependent mass transfers: the Garonne river and its tributaries (SW France). Chem. Geol., 168, 173-193.

Sheppard, S.M.F., 1986, Characterization and isotopic variations in natural waters, in Stable Isotopes In High Temperature Geological Processes. Reviews in Mineralogy Vol. 16, edited by J.W. Valley, H.P. Taylor, J.R. O'Neil, 165-184.

Simpson, H.J. and Herzeg, A.L., 1991, Stable isotopes as an indicator of evaporation in the River Murray, Australia. Water Resour. Res., 27, 1925-1935.

Singer, P. C., Ed., 1999, Formation and Control of Disinfection By-Products in Drinking Water, American Water Works Association, Denver, CO

Sklash, M.G. and Farvolder, R.N. 1979, The role of groundwater in storm runoff. $J$. Hydrol., 43, 45-65.

Smith, B.N. and Epstein, S., 1971, Two catagories of ${ }^{13} \mathrm{C} /{ }^{12} \mathrm{C}$ ratios for higher plants. Plant Physiol. 47, 380-384.

Snow, D.D. and Spalding, R.F., 1994, Uranium isotopes in the Platte River drainage basin of the North American High Plains Region. Appl. Geochem., 9, 271-278.

Stallard, R.F. and Edmond J.M., 1981, Geochemistry of the Amazon. 1. Precipitation chemistry and the marine contribution to the dissolved load at the time of peak discharge. J. Geophys. Res., 86, 9844.

Stamer, J.K., 1996, Water supply implications of herbicide sampling. J. $A W W A, 88,76-$ 85 
Stevenson, F.J., 1985, Geochemistry of soil humic substances. In (Aiken, G.R., McKnight, D.M., Wershaw, R.L., eds) Humic Substances in Soil, Sediment, and Water. John Wiley and Sons New York, pp. 13-52.

Stewart, M.K., 1975, Stable isotope fractionation due to evaporation and isotopic exchange of falling waterdrops: Applications to atmospheric processes and evaporation of lakes. J. Geophys. Res., 80, 1133-1146.

Stuiver, M. and Polach, H., 1977, Reporting of ${ }^{14} \mathrm{C}$ data. Radiocarbon, 19, 355-363

Sweet, M.S. and Perdue, E.M., 1982, Concentration and speciation of dissolved sugars in river water. Environ. Sci. Technol., 16, 692-698.

Swisher, R.D., 1987, Surfactant Biodegradation. $2^{\text {nd }}$ ed. Marcel Dekker, NY.

Taylor, H.P., Jr., 1974, The application of oxygen and hydrogen isotope studies to problems of hydrothermal alteration and ore deposition. Econ. Geol., 69, 843-883.

Telmer, K. and Veizer, J., 1999, Carbon fluxes, $p \mathrm{CO}_{2}$, and substrate weathering in a large northern river basin, Canada: carbon isotope perspectives. Chem. Geol., 159, 61-86.

Thurman, E.M., and Malcolm, R.L., 1981, Preparative isolation of aquatic humic substances. Environ. Sci. Technol., 15, 463-466.

Thurman, E.M., 1985, Organic Geochemistry of Natural Waters. Martinus Nijhoff/Dr W. Junk Publishers: Boston, 497 pp.

Thurman, E.M.; Goolsby, D.A.; MeyerR, M.T.; and Kolpin, D.W., 1991, Herbicides in surface waters of the midwestern United States: The effect of spring flush. Environ. Sci. Technol., 25:1794

Tibbetts J., 1996, Ocean commotion. Environ Health Perspect., 104, 380-385.

Tilzer, M.M., 1987, Environmental and physiological control of phytoplankton productivity in large lakes. In Tilzer, M.M. and Serruya, C. eds. Large Lakes, Springer-Verlag: Berlin, 339-367.

Torn, M.S., Trumbore, S.E., Chadwick, O.A., and others, 1997, Mineral control of soil organic storage and turnover. Nature, 389, 170-173.

Trumbore, S.E., 1993, Comparison of carbon dynamics in tropical and temperate soils using radiocarbon measurements. Global Biogeochemical Cycles, 7, 275-290.

Van der Leeden, F., 1975, Water Resources of the World: Selected Statistics. Water Information Center, Port Washington, NY.

Vogel, J.S.; Southon, J.R.; Nelson, D.E., 1987, Catalyst and binder effects in the use of filimentous graphite in AMS. Nuclear Instruments and Methods in Physics Research., B29, 50-56.

Wadleigh, M.A., Veizer, J., Brooks, C., 1985, Strontium and its isotopes in Canadian rivers: Fluxes and global implications. Geochim. Cosmochim. Acta, 49, 1727-1736.

Wassenaar, L. Aravena, R., Fritz, P. Baker, J., 1990, Isotopic composition $\left({ }^{13} \mathrm{C},{ }^{14} \mathrm{C},{ }^{2} \mathrm{H}\right)$ and geochemistry of aquatic humic substances from groundwater. Org. Geochem., 15, 383-396.

Wassenaar L.I., 1995. Evaluation of the origin and fate of nitrate in the Abbotsford aquifer using the isotopes of N-15 and O-18 in NO3-. Applied Geochemistry, 10, 391405 .

Wedin, D.A., Tiezin, L.L., Dewey, B., Pastor, J., 1995, Carbon isotope dynamics during grass decomposition and soil organic matter formation. Ecology, 76, 1383-1392. 
Wershaw, R.L., Leenheer, J.A., Kennedy, K.R., Noyes, T.I., 1996, Use of ${ }^{13} \mathrm{C}$ NMR and FTIR for elucidation of degradation pathways during natural litter decomposition and composting. 1. Early stage leaf degradation. Soil Sci., 161, 667-679.

Williams, P.M., Roberston, K.J., Soutar, A. et al., 1992, Isotopic signatures $\left({ }^{13} \mathrm{C},{ }^{14} \mathrm{C}\right.$, ${ }^{15} \mathrm{~N}$ ) as tracers of sources and cycling of soluble and particulate organic matter in the Santa Monica Basin, California. Prog. Oceanogr., 30, 253-290.

Yang, C., Telmer, K., Veizer, J., 1996, Chemical dynamics of the "St. Lawrence" riverine system: $\delta \mathrm{DH} 2 \mathrm{O}, \delta^{18} \mathrm{OH} 2 \mathrm{O}, \delta^{13} \mathrm{CDIC}, \delta^{34} \mathrm{Ssulfate}$, and dissolved ${ }^{87} \mathrm{Sr} /{ }^{86} \mathrm{Sr}$. Geochim. Cosmochim. Acta, 60: 851-866.

Zielinski, R.A., AsherBolinder, S., Meier, A.L., and others, 1997, Natural or fertilizerderived uranium in irrigation drainage: A case study in southeastern Colorado, USA. Appl. Geochem., 12, 9-21. 
Appendices 


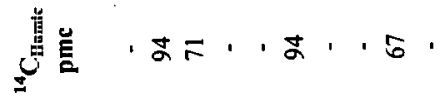

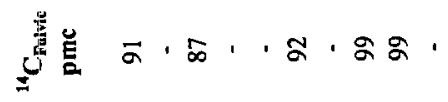

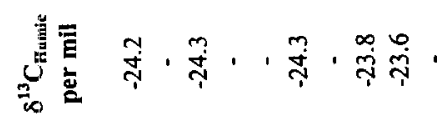

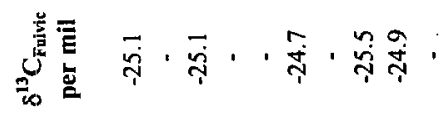

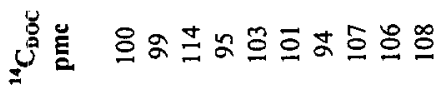

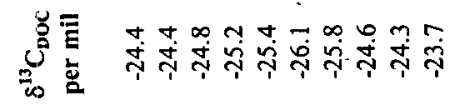

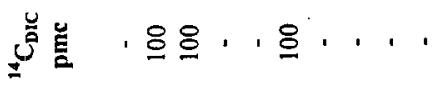

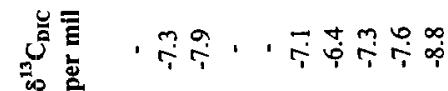

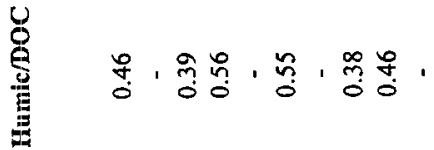

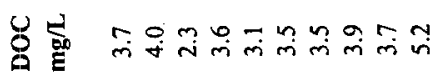

足立

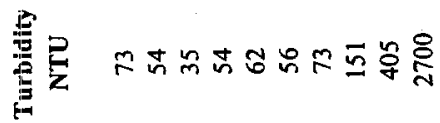

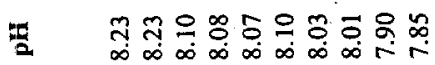

ए

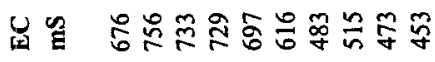

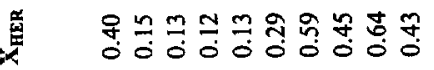

离

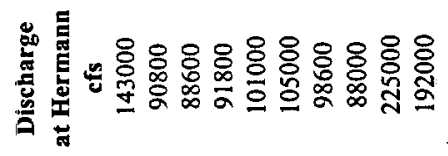

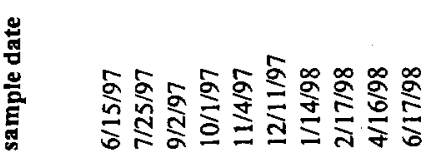




\begin{tabular}{|c|c|c|c|c|c|c|c|c|c|c|}
\hline & $\begin{array}{l}\text { sample } \\
\text { date }\end{array}$ & $\mathrm{EC}(\mu \mathrm{s})$ & pH & $\mathrm{T}^{\circ} \mathrm{C}$ & $\begin{array}{l}\text { DOC } \\
\mathrm{mg} / \mathrm{L}\end{array}$ & $\begin{array}{c}\delta^{18} \mathrm{O} \\
\text { per mil }\end{array}$ & $\begin{array}{c}\delta^{13} \mathrm{C}-\mathrm{DOC} \\
\text { per mil }\end{array}$ & $\begin{array}{c}\delta^{13} \mathrm{C} \text {-DIC } \\
\text { per mil }\end{array}$ & $\begin{array}{c}{ }^{14} \mathrm{C}-\mathrm{DOC} \\
\text { pme }\end{array}$ & $\begin{array}{c}{ }^{14} \mathrm{C}-\mathrm{DIC} \\
\text { pme }\end{array}$ \\
\hline \multicolumn{11}{|c|}{ Rivers and Springs in St. Louis, MO Area } \\
\hline Missouri River & $3 / 27 / 97$ & 390 & 8.2 & 11.2 & - & -10.0 & - & -7.7 & - & 100 \\
\hline below Lewis & $7 / 23 / 97$ & 900 & 8.0 & 29.1 & - & -10.9 & - & -7.3 & 107 & 109 \\
\hline \multirow[t]{3}{*}{ Bridge } & $11 / 3 / 97$ & 490 & 8.3 & 10.1 & - & -12.7 & - & -7.0 & - & 99 \\
\hline & $4 / 14 / 98$ & 360 & 8.0 & 12.4 & 3.0 & -8.7 & - & -4.5 & 95 & - \\
\hline & $10 / 1 / 98$ & 444 & 8.1 & 23.8 & $3: 8$ & -7.7 & - & -9.1 & - & - \\
\hline Mississippi River & $3 / 27 / 97$ & 285 & 8.1 & 9.8 & - & -9.9 & -23.4 & -9.1 & 108 & 97 \\
\hline below Clark & $7 / 23 / 97$ & 495 & 8.0 & 30.2 & - & -7.8 & - & -7.5 & - & 101 \\
\hline \multirow[t]{2}{*}{ Bridge } & $11 / 3 / 97$ & 300 & 8.3 & 9.4 & - & -7.2 & -25.4 & -8.5 & 109 & 105 \\
\hline & $4 / 14 / 98$ & 346 & 8.0 & 13.2 & 5.1 & -8.8 & -25.5 & -8.9 & 106 & - \\
\hline Mississippi River & $3 / 27 / 97$ & 280 & 8.2 & 9.1 & - & -10.0 & - & -12.9 & - & 85 \\
\hline Winfield Ferry & $7 / 23 / 97$ & 475 & 8.0 & 30.5 & - & -7.6 & - & -8.0 & - & 101 \\
\hline \multirow[t]{4}{*}{ below L\&D 25} & $7 / 23 / 97$ & 485 & 8.0 & 30.1 & - & -7.6 & - & $\therefore$ & - & 102 \\
\hline & $11 / 3 / 97$ & 320 & 8.0 & 8.8 & - & -7.5 & - & -8.1 & - & 102 \\
\hline & $4 / 14 / 98$ & 360 & 8.2 & 15.7 & 4.1 & -9.2 & - & -7.2 & - & - \\
\hline & $10 / 1 / 98$ & 402 & 8.1 & 23.1 & 4.4 & -7.1 & - & -8.6 & - & - \\
\hline Mississippi River & $7 / 23 / 97$ & 315 & 8.0 & 9.2 & - & -7.3 & - & & - & - \\
\hline \multirow[t]{2}{*}{ above L\&D 25} & $11 / 3 / 97$ & 353 & 8.0 & 12.8 & - & -9.0 & -25.6 & -8.6 & - & - \\
\hline & $4 / 14 / 98$ & - & - & - & 4.9 & - & - & -8.6 & - & - \\
\hline Mississippi River & $7 / 23 / 97$ & 300 & 8.2 & 9.3 & - & -7.3 & - & & - & - \\
\hline \multirow[t]{3}{*}{ below L\&D 26} & $11 / 3 / 97$ & 475 & 8.0 & 30.8 & - & -7.7 & - & & - & 99 \\
\hline & $4 / 19 / 98$ & 475 & 7.8 & 29.6 & 2.6 & -7.8 & -26.7 & & - & 101 \\
\hline & $10 / 1 / 98$ & 413 & 8.0 & 24.0 & 4.6 & -7.8 & - & -8.8 & - & - \\
\hline Illinois River & $3 / 27 / 97$ & 470 & 8.2 & 10.6 & - & -7.7 & - & -8.4 & - & 93 \\
\hline \multirow[t]{4}{*}{ at Hardin, Ill. } & $7 / 23 / 97$ & 850 & 8.0 & 30.3 & - & -5.7 & - & -7.1 & - & 95 \\
\hline & $11 / 3 / 97$ & 700 & 8.1 & 11.2 & - & .5 .5 & - & -6.9 & - & 117 \\
\hline & $4 / 14 / 98$ & 576 & 8.2 & 14.5 & 4.3 & -8.1 & -24.1 & -8.5 & - & - \\
\hline & $10 / 1 / 98$ & 665 & 8.0 & 23.7 & 3.7 & -5.3 & - & -7.8 & - & - \\
\hline Meremac River & $3 / 25 / 97$ & 190 & 8.2 & 12.1 & - & -6.7 & - & -12.4 & - & 97 \\
\hline below Hwy W & $7 / 23 / 97$ & 350 & 8.1 & 29.5 & . & -5.9 & - & -10.9 & - & 91 \\
\hline \multirow[t]{7}{*}{ bridge } & $11 / 4 / 97$ & 280 & 7.9 & 10.1 & $\therefore$ & -6.1 & - & -10.6 & - & 86 \\
\hline & $4 / 15 / 98$ & 225 & 8.3 & 17.2 & 3.9 & -7.3 & - & -11.3 & - & - \\
\hline & $4 / 16 / 98$ & 149 & 8.0 & 14.8 & 5.8 & -6.1 & -26.3 & -11.7 & 111 & - \\
\hline & $4 / 16 / 98$ & - & - & - & - & - & -26.1 & - & - & - \\
\hline & $4 / 17 / 98$ & 175 & 8.0 & 14.8 & 4.7 & -7.2 & - & - & - & - \\
\hline & $4 / 19 / 98$ & 213 & 7.9 & 14.4 & 3.5 & -7.4 & -26.1 & - & 107 & - \\
\hline & $10 / 2 / 98$ & 315 & 8.2 & 21.0 & 1.2 & -6.5 & - & -11.6 & - & - \\
\hline $\begin{array}{l}\text { Meremac River } \\
\text { below Hwy } 8\end{array}$ & $4 / 16 / 98$ & 228 & 8.2 & 15.3 & 1.9 & -7.7 & - & - & - & - \\
\hline $\begin{array}{l}\text { Meremac Spring } \\
\text { State Park }\end{array}$ & $4 / 16 / 98$ & 199 & 7.6 & 12.6 & 1.9 & -7.9 & - & -13.2 & 106 & 106 \\
\hline Big River & $3 / 25 / 97$ & 280 & & & & & & & & \\
\hline below Twin Rivers & $11 / 4 / 97$ & 360 & $\begin{array}{l}8.1 \\
8.1\end{array}$ & 10.1 & - & $\begin{array}{l}-6.4 \\
-6.1\end{array}$ & - & - & $\because$ & - \\
\hline \multirow[t]{4}{*}{ Bridge } & $4 / 15 / 98$ & 368 & 8.6 & 17.2 & 2.1 & .7 .2 & - & -10.0 & - & - \\
\hline & $4 / 16 / 98$ & 219 & 7.9 & 14.4 & - & -6.1 & - & - & - & - \\
\hline & $4 / 17 / 98$ & 306 & 8.1 & 15.7 & - & -7.2 & - & - & - & - \\
\hline & $10 / 2 / 98$ & 457 & 8.2 & 20.3 & 2.2 & -5.9 & - & - & - & - \\
\hline Rockwood Spring & $11 / 4 / 97$ & 750 & 6.9 & 12.7 & - & -8.1 & - & - & - & - \\
\hline at Rockwood & $4 / 15 / 98$ & 360 & 7.6 & 11.0 & 3.8 & -8.7 & -25.7 & -13.2 & 110 & - \\
\hline Reservation & $10 / 1 / 98$ & 748 & 7.1 & 13.6 & 1.8 & - & - & - & - & - \\
\hline \multicolumn{11}{|c|}{ Other Rivers in State of Missouri } \\
\hline Burbouse River & $4 / 16 / 98$ & 128 & 8.0 & 14.0 & 6.8 & -6.9 & - & - & - & - \\
\hline Cuiver River & $4 / 17 / 98$ & 203 & 7.8 & 14.4 & 8.4 & -6.0 & - & - & - & - \\
\hline Salt River & $4 / 17 / 98$ & 195 & 8.0 & $11: 6$ & 7.0 & -9.2 & - & - & - & - \\
\hline N. Fork Salt River & $4 / 17 / 98$ & 181 & 8.0 & 13.6 & 7.8 & -6.1 & $\cdot$ & - & - & - \\
\hline Chariton River & $4 / 18 / 98$ & 309 & - & 11.3 & 5.8 & -7.2 & - & - & - & - \\
\hline Grand River & $4 / 18 / 98$ & 255 & 8.1 & 11.4 & 5.8 & -7.3 & - & - & - & - \\
\hline $\begin{array}{l}\text { Missouri River } \\
\text { at St. Joseph, MO }\end{array}$ & $4 / 18 / 98$ & 686 & 7.9 & 12.0 & 3.8 & -10.7 & - & -9.6 & 101 & - \\
\hline $\begin{array}{l}\text { Missouri River } \\
\text { below Hwy. } 13\end{array}$ & $4 / 18 / 98$ & 660 & 8.1 & 14.0 & 3.4 & -9.6 & - & -7.1 & - & - \\
\hline Kansas River & $4 / 18 / 98$ & 574 & 8.1 & 13.2 & 5.4 & -7.3 & -22.5 & - & 104 & - \\
\hline
\end{tabular}


Table 3: Sample Locations of California Rivers

\begin{tabular}{|c|c|c|c|c|c|c|c|}
\hline Sample Site & Latitude & Longitude & Sources & $\begin{array}{c}\text { Upstream } \\
\text { Reservoir } \\
\text { Capacity } \\
\text { (106 acre-ft) }\end{array}$ & $\begin{array}{l}\text { Maximum } \\
\text { Residence } \\
\text { Time (yrs) }\end{array}$ & $\begin{array}{c}\text { Multi- } \\
\text { tsotope } \\
\text { Measured }\end{array}$ & $\begin{array}{c}\text { Repeat } \\
\text { Sampling }\end{array}$ \\
\hline $\begin{array}{l}\text { American River } \\
\text { Below Folsom } \\
\text { Dam }\end{array}$ & $38^{\circ} 42^{\prime} 18.4^{\prime \prime}$ & $121^{\circ} 09^{\prime} 32.6^{\prime \prime}$ & Sierra NV & 1.80 & 0.63 & yes & no \\
\hline South Fork . & $38^{\circ} 48^{\prime} 11.9^{\prime \prime}$ & $120^{\circ} 53^{\prime} 24.8^{\prime \prime}$ & Sierra NV & 0.38 & 0.35 & yes & yes \\
\hline $\begin{array}{l}\text { North and Middle } \\
\text { Forks }\end{array}$ & $38^{\circ} 54^{\prime} 58.6^{\prime \prime}$ & $121^{\circ} 0220.0^{\prime \prime}$ & SierTa NV & 0.46 & & yes & no \\
\hline North Forlk & $38^{\circ} 54^{\prime} 58.6^{\prime \prime}$ & $121^{\circ} 02^{\prime} 20.0^{n}$ & Sierra NV & 0.02 & 0.03 & no & yes \\
\hline Middle Fork & $38^{\circ} 54^{\prime} 58.6^{\prime \prime}$ & $121^{\circ} 02.20 .0^{\prime \prime}$ & Sierra NV & 0.44 & 0.51 & no & yes \\
\hline South Fork & $38^{\circ} 45^{\prime} 45.9^{\prime \prime}$ & $120^{\circ} 19^{\prime 2} 27.2^{\prime \prime}$ & Sierra NV & 0.03 & 0.12 & no & yes \\
\hline Sacramento & Natt Ave. Bridge & & Sіепта NV & 180 & 0.63 & yes & yes \\
\hline $\begin{array}{l}\text { Cache Creek } \\
\text { Rd. } 102 \text { Crossing }\end{array}$ & $38^{\circ} 43^{\prime} 32.3^{\prime \prime}$ & $121^{\circ} 43^{\prime} 44.1^{\prime \prime}$ & Coast Range & 0.34 & 0.76 & yes & yes \\
\hline Conral Hollow Creek & $37^{\circ} 38^{\prime} 5^{\prime \prime}$ & $121^{\circ} 32^{\prime} 33^{\prime \prime}$ & Coast Range & 0.00 & 0.00 & yes & yes \\
\hline $\begin{array}{l}\text { Consumnes River } \\
\text { Latrobe Rd } \\
\text { Crossing }\end{array}$ & $38^{\circ} 31^{\prime} 20.6^{\prime \prime}$ & $120^{\circ} 57^{\prime} 17.6^{\prime \prime}$ & Sierra NV & 0.04 & 0.10 & no & \\
\hline Hwy 49 Crossing & $38^{\circ} 33^{\prime} 14.9^{n}$ & $120^{\circ} 50^{\prime} 53.9^{\prime \prime}$ & Sierra NV & 0.04 & 0.10 & no & \\
\hline $\begin{array}{l}\text { Eeather River } \\
2 \mathrm{mi} \text {. N of Verona }\end{array}$ & $38^{\circ} 48^{\prime} 52.8^{\prime \prime}$ & $121^{\circ} 38^{\prime} 7.0^{\prime \prime}$ & Sierra NV & 7.20 & 1.20 & & \\
\hline $\begin{array}{l}\text { HWY } 99 \text { at } \\
\text { Nicklaus }\end{array}$ & & & Sierra NV & 7.20 & 1.20 & & \\
\hline$\frac{\text { Los Banou Creek }}{\text { Hwy. } 140 \text { Crossing }}$ & & & Mix & NA & & & \\
\hline $\begin{array}{l}\text { Merced River } \\
\text { Hwy. } 140 \text { at Bear Cr. } \\
\text { Confluence }\end{array}$ & $37^{\circ} 36^{\prime} 15.8^{\prime \prime}$ & $119^{\circ} 5758.5$ & Sierra NV & 0.00 & 0.00 & no & \\
\hline $\begin{array}{l}\text { Hwy } 120 / \text { Hwy. } 140 \\
\text { Intersection }\end{array}$ & $37^{\circ} 43^{\prime} 249^{\prime \prime}$ & $119^{\circ} 40^{\prime} 47.0^{\prime \prime}$ & Sierra NV & 0.00 & 0.00 & по & \\
\hline$\frac{\text { Middle River }}{\text { Hwy. } 4 \text { Crossing }}$ & $37^{\circ} 53^{\prime 2} 21.8^{n}$ & $121^{\circ} 29^{\prime} 14.7$ & Delta Mix & NA & & & \\
\hline $\begin{array}{l}\text { Mokelumne River } \\
\text { Cty. Rd. } 112 \text { Crossing } \\
\text { N. Lodi }\end{array}$ & $38^{\circ} 1121.3^{\prime \prime}$ & $121^{\circ} 19^{\prime} 14.4^{\prime \prime}$ & Sierra NV & 0.86 & 1.50 & & \\
\hline Hwy. 88 Crossing & $38^{\circ} 1224.7^{\prime \prime}$ & $121^{\circ} 03^{\prime} 59.5^{\prime \prime}$ & Sierra NV & 0.86 & 1.50 & & \\
\hline Hwy. 49 Crossing & $38^{\circ} 18^{\prime} 46.1^{\prime \prime}$ & $120^{\circ} 43^{\prime} 12.7^{\prime \prime}$ & Sierra NV & 0.22 & 0.28 & no & \\
\hline Hwy..12 Crossing & $38^{\circ} 07^{\prime} 38.8^{\prime \prime}$ & $121^{\circ} 34^{4} 42.8^{4}$ & Delta Mix & 0.92 & 1.60 & & \\
\hline $\begin{array}{l}\text { Mud Slough } \\
\text { Hwy. } 140 \text { Crossing }\end{array}$ & & & $\operatorname{Mix}$ & NA & & & \\
\hline$\frac{\text { Old River }}{\text { Hwy. } 4 \text { Crossing }}$ & $37^{\circ} 5324.2^{m}$ & $121^{\circ} 34^{\circ} 4.3^{\prime \prime}$ & Delta Mix & NA & & & \\
\hline $\begin{array}{l}\text { Putah Creck } \\
\text { Old Davis Rd } \\
\text { Crossing }\end{array}$ & $38^{\circ} 31^{\circ} 02.7^{\prime \prime}$ & $121^{\circ} 45^{\prime} 25.2^{\prime \prime}$ & Coast Range & 1.60 & 4.20 & & \\
\hline Sacramento River & + & & & & & & \\
\hline $1-80$ Crossing & $38^{\circ} 36^{\prime} 00^{\prime \prime}$ & $121^{\circ} 32^{\prime} 32.2^{\prime \prime}$ & $\begin{array}{l}\text { Cascades } \\
\text { Sierra NV }\end{array}$ & 14.90 & 0.99 & & $\therefore$ \\
\hline Knights Landing & $38^{\circ} 48^{\circ} 08.6^{\prime \prime}$ & $121^{\circ} 43^{\prime} 15.4^{\prime \prime}$ & $\begin{array}{l}\text { Cascades } \\
\text { Sierra NV }\end{array}$ & 7.70 & 0.99 & & \\
\hline Rio Vista & $38^{\circ} 09^{\prime} 18.6^{\prime \prime}$ & $121^{\circ} 4 l^{\prime} 18.3^{\prime \prime}$ & Delta Mix & $15: 90$ & 0.90 & & \\
\hline $\begin{array}{l}\text { Hwy. } 160 \text { at } \\
\text { Paintersville }\end{array}$ & $38^{\circ} 19^{\circ} 16.2^{\prime \prime}$ & $121^{\circ} 34^{\prime} 38.4^{\prime \prime}$ & $\begin{array}{l}\text { Cascades } \\
\text { Sierta NV }\end{array}$ & 15.90 & 0.90 & & \\
\hline $\begin{array}{l}\text { Hoy. } 160 \text { at } \\
\text { Isleton }\end{array}$ & & & $\begin{array}{l}\text { Cascades } \\
\text { Sierra NV }\end{array}$ & 15.90 & 0.90 & & \\
\hline
\end{tabular}


Table 3: Sample Locations of California Rivers

Sample Site Latitude Longitude Sources

Salt Slough

Hwy. 165 Crossing

San Joaquin River

Hwy. 132 Crossing

1-5 Crossing

Powerhouse Rd $6 \mathrm{mi} \mathrm{N}$. Aubury

Below Friant Dam

Hwy. 145 Crossing

Chowchilla Canal Rd.

Nr. Hwy 33

Firebaugh|

Hwy. 140 Crossing

Sherman Island

Levee Rd.

Hot Rd. Neuberger

Rd. Intersection

W. Stockton

Stanislaus River

Below New Melones Dam

Riverbank near Hwy. 10:3

Cassel State Park

North Fork

South of Calaveras

Big Trees Park

North Fork

Below Stanislaus

Power House

Tuolume River

Fth St. Crossing Modesto

Cry. Rd. 559 1/4 mi N. Hwy. 132

Wards Ferry Rd. Crossing

South Fork Hwy. 12.0 Crossing

Middle Fork Cherry lake Rd.

$36^{\circ} 46.55^{\prime \prime}$

$36^{\circ} 51^{\prime} 22.1^{\prime \prime} \quad 120^{\circ} 26^{\circ} 48.7^{\prime \prime}$

$37^{\circ} 18^{\prime} 33.2^{\prime \prime}$
Upstream

Reservoir

Capacity

(10 acre-ft)

Mix NA

$37^{\circ} 38^{\prime} 22.5^{\prime \prime} \quad 121^{\circ} 13^{\prime} 42^{\prime \prime} \quad$ Mix NA

$3^{\circ} 47.149^{\prime} \quad 121^{\circ} 18.353^{\prime}$ Delta Mix

$37^{\circ} 08^{\prime} 40.7^{\prime \prime} \quad 119^{\circ} 30^{\prime} 05.2^{\prime \prime} \quad$ Sierra NV 0.60

$36^{\circ} 58^{\prime} 45^{\prime \prime} \quad 119^{\circ} 43^{\prime} 49.1^{\prime \prime}$ Sierra NV 1.20

36049'23.3" $120^{\circ} 03^{\prime} 15.4^{\prime \prime}$ Sierra NV

$38^{\circ} 02^{\prime} 48.7^{\prime \prime} \quad 121^{\circ} 43^{\prime} 02.5^{\prime \prime} \quad$ Delta Mix

$37^{\circ} 59^{\prime} 40.7^{\prime \prime} \quad 121^{\circ} 24^{\prime} 39.1^{\prime \prime} \quad$ Delta Mix

NA

$37^{\circ} 56.944^{\prime} \quad 120^{\circ} 31.940^{\prime} \quad$ Sierra NV

$37^{\circ} 44.523^{\prime} \quad 120^{\circ} 56.301^{\circ}$ Sierra NV

2.50

$37^{\circ} 41.627^{\prime} \quad 120^{\circ} 10.767 \quad$ Sierra NV

$38^{\circ} 16^{\prime} 17.5^{\prime \prime} \quad 120^{\circ} 16^{\circ} 09.0^{\prime \prime}$ Sierra NV

2.50

0.20

$38^{\circ} 08^{\prime} 2.3^{\prime \prime} \quad 120^{\circ} 22^{\prime} 46.8^{\prime \prime}$ Sierra NV

0.20

$3^{\circ} 37.569^{\circ} \quad 120^{\circ} 59.516^{\prime} \quad$ Sierra NV

2.70

$3^{\circ} 40.004^{\prime} \quad 120^{\circ} 28.238^{\prime} \quad$ Sierra NV

2.60

$37^{\circ} 52^{\prime} 38.5^{\prime \prime} \quad 120^{\circ} 17^{\prime 35} 32^{\prime \prime} \quad$ Sierra NV $\quad 0.66$

$37^{\circ} 49^{\prime} 17.3^{\prime \prime} \quad 120^{\circ} 00^{\prime} 42.3^{\prime \prime} \quad$ Sierra NV

$37^{\circ} 49^{\prime 41} 1^{\prime \prime} \quad 120^{\circ} 00^{\prime} 8.4^{\prime \prime} \quad$ Sierra NV
0.23

Maximum

Multi- Repeat

Isotope Sampling Time (yrs) Measured

1.30

2.20

2.40

2.40

2.40

0.23 no

no 


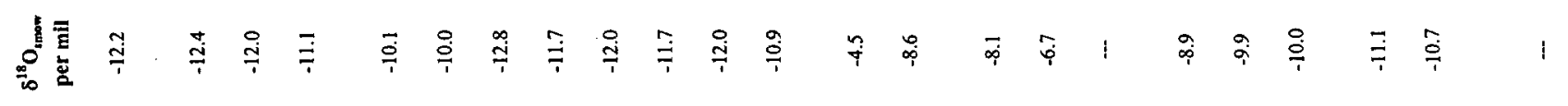

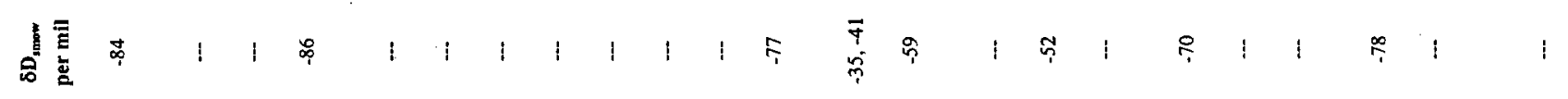

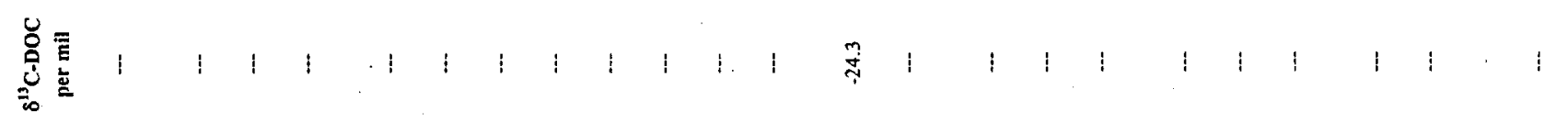

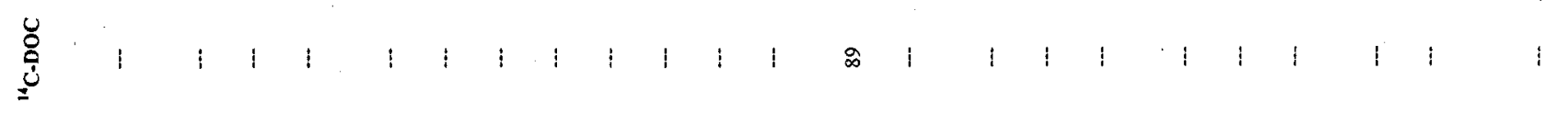

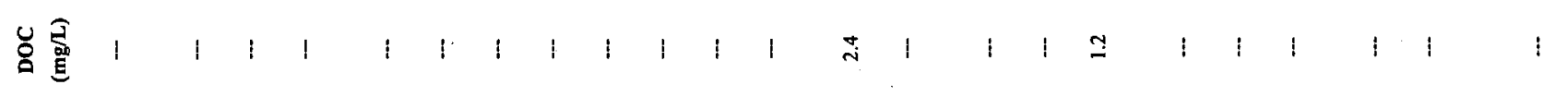

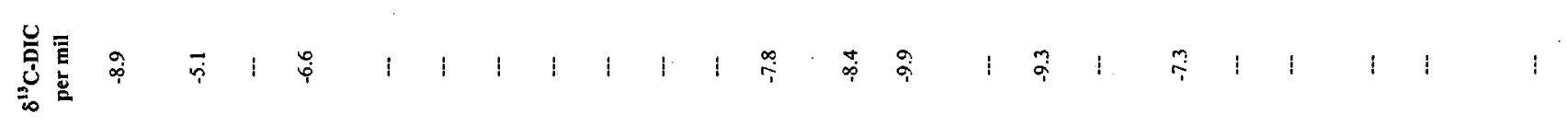

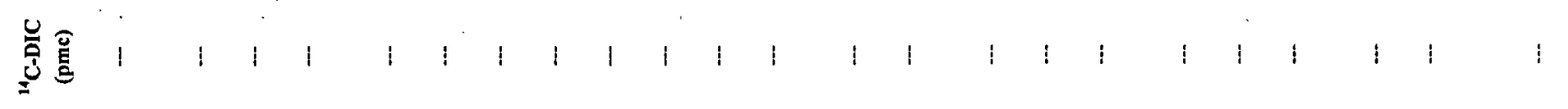

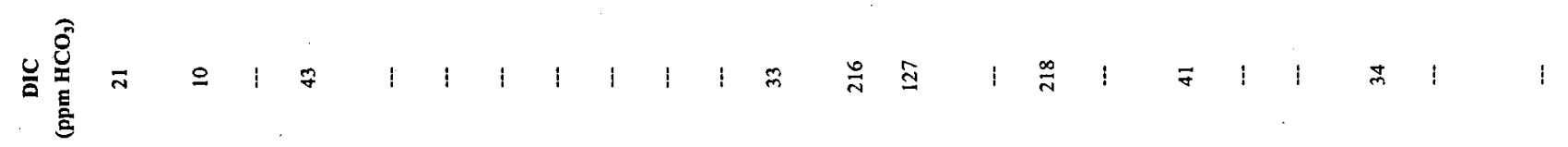

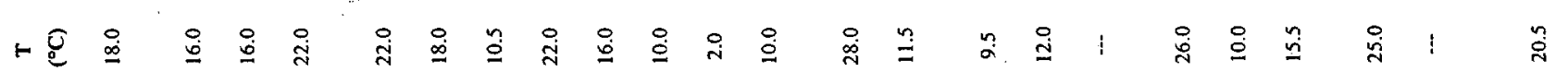

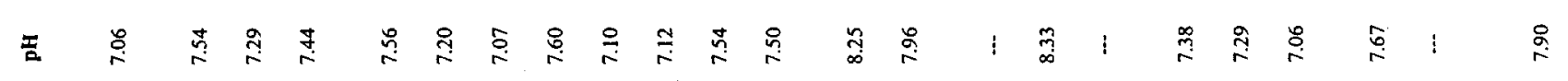

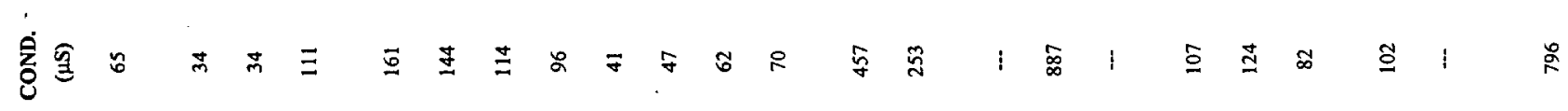

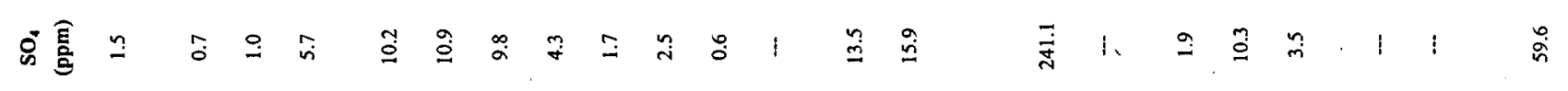

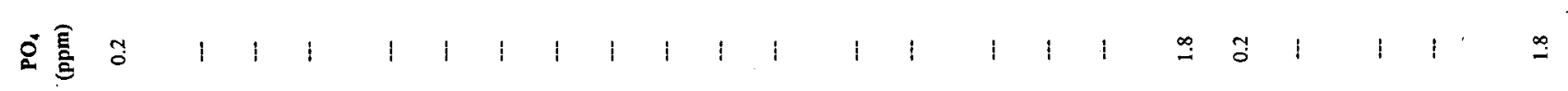

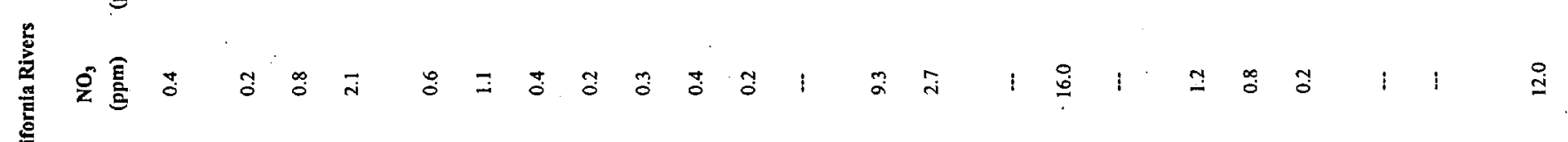

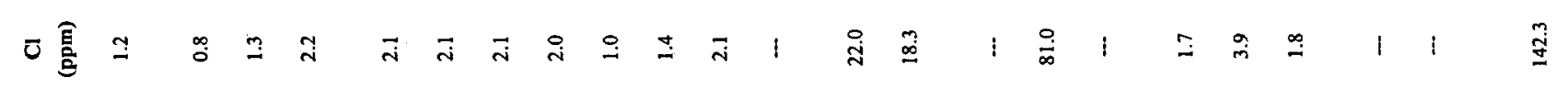

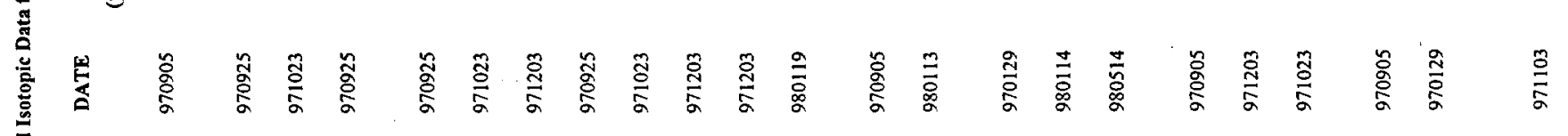

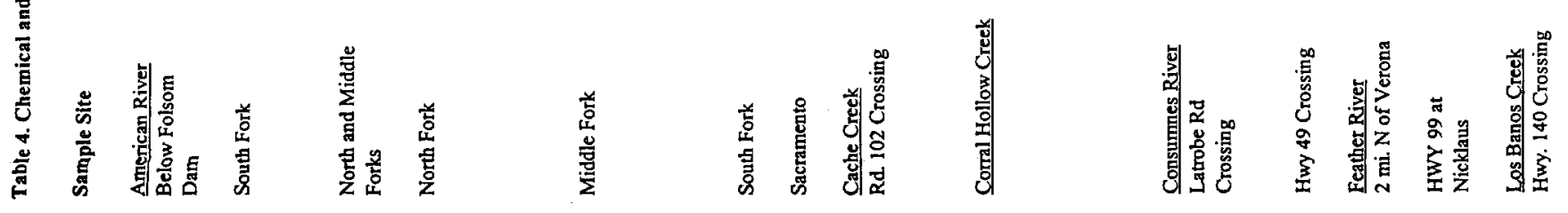




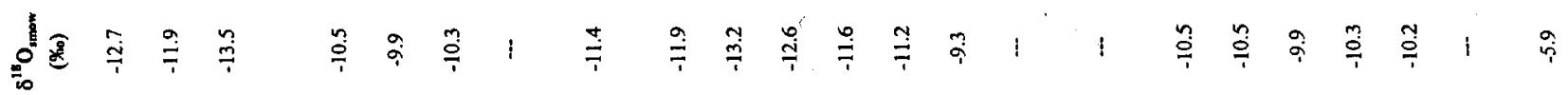

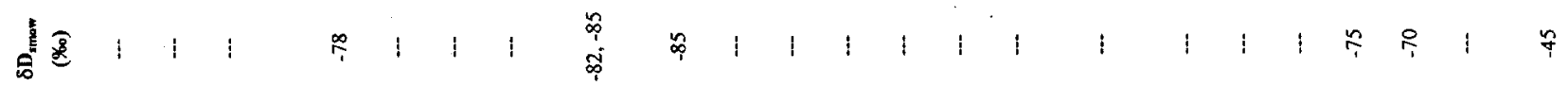

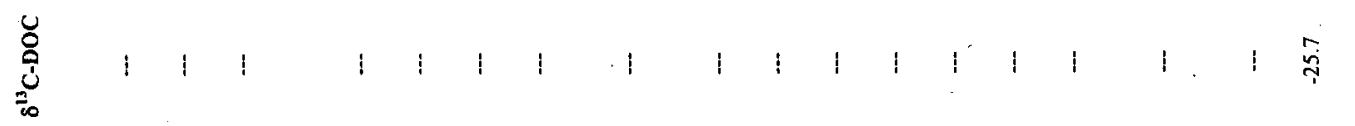

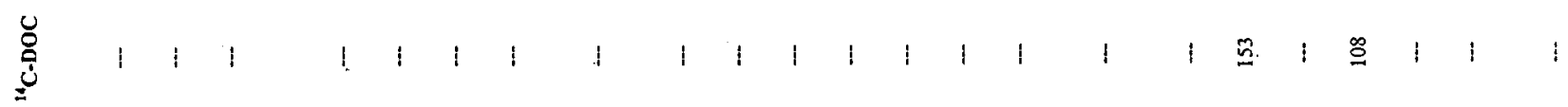

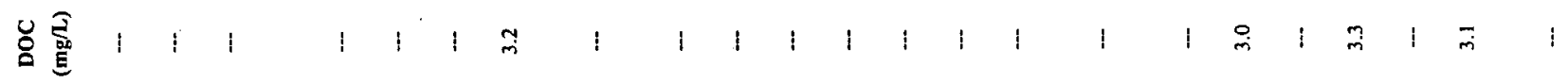

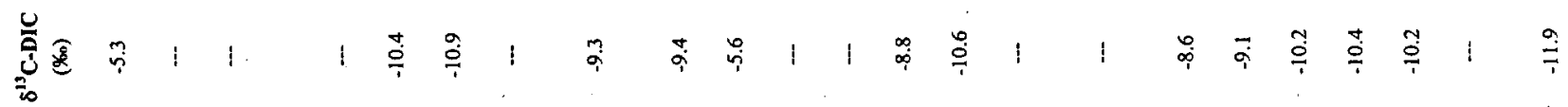

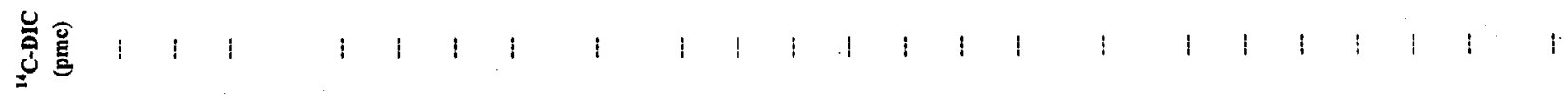

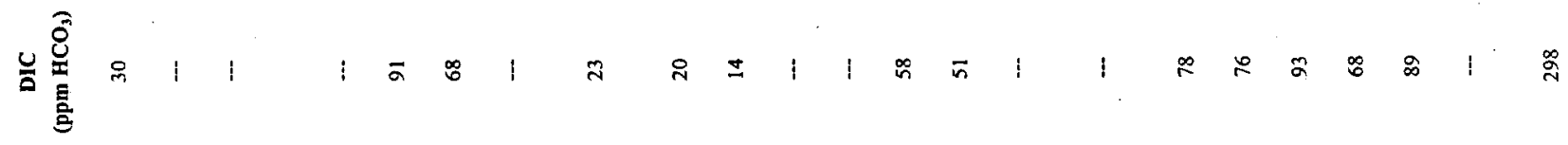

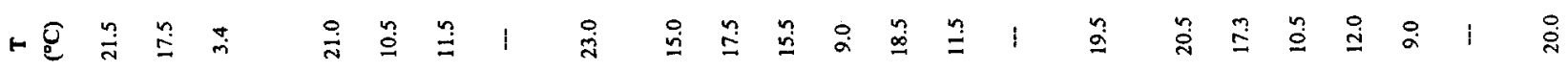

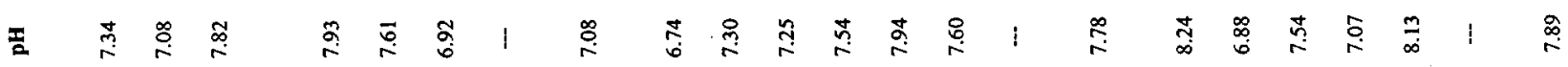

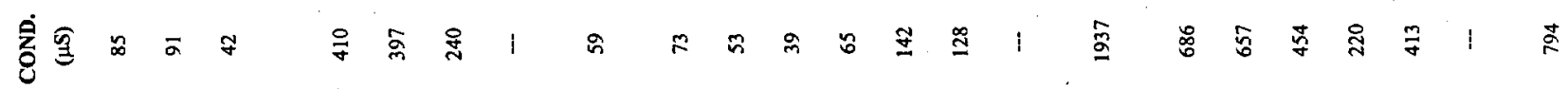

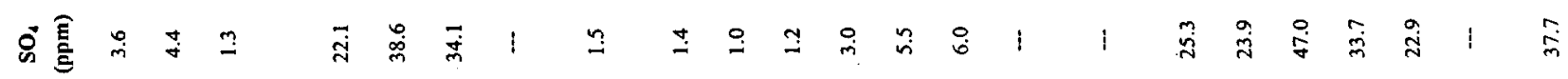

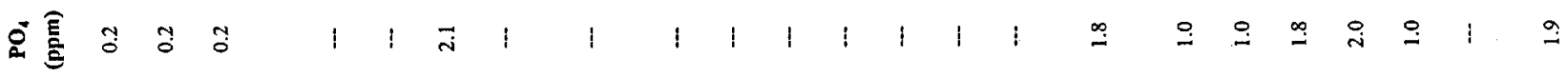

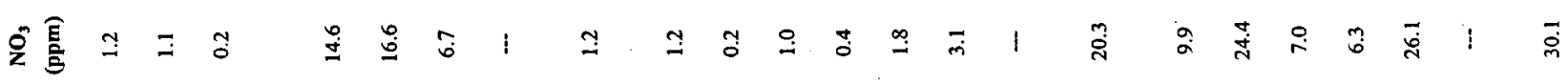

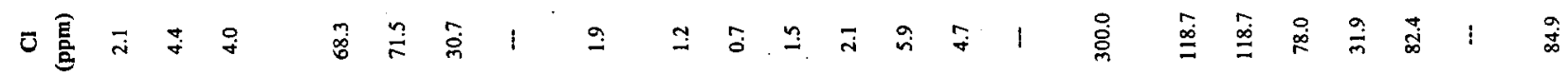

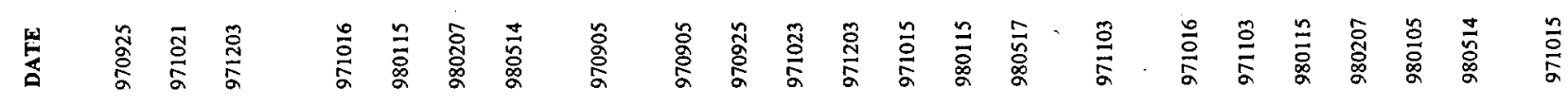

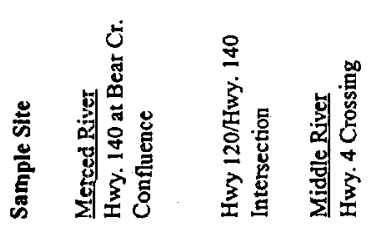
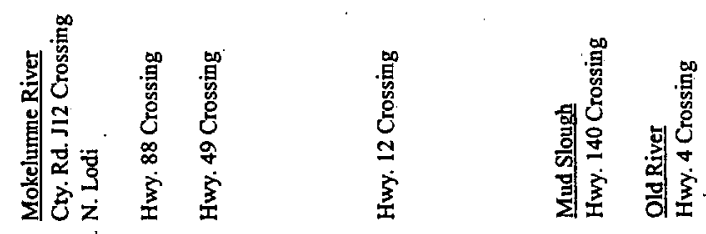


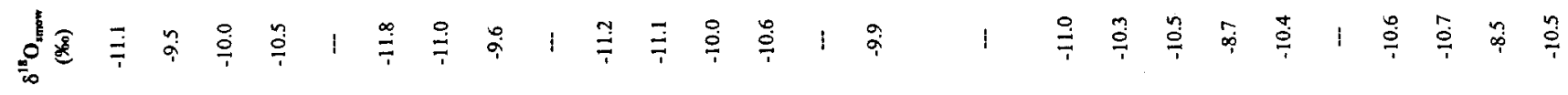

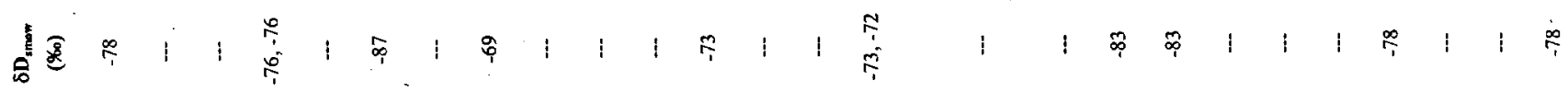
蔗

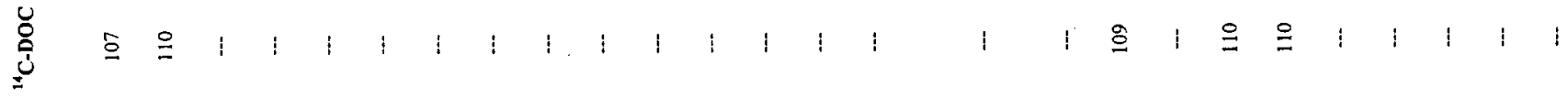

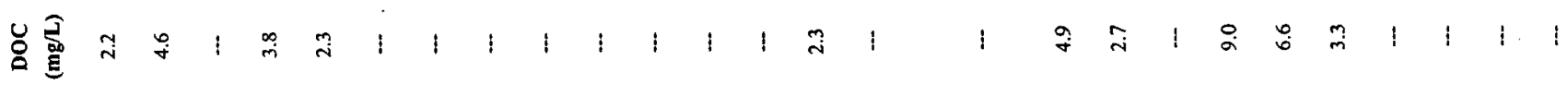

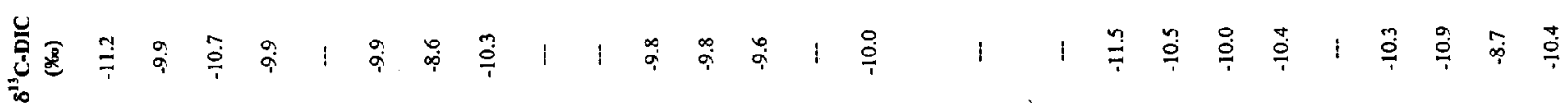

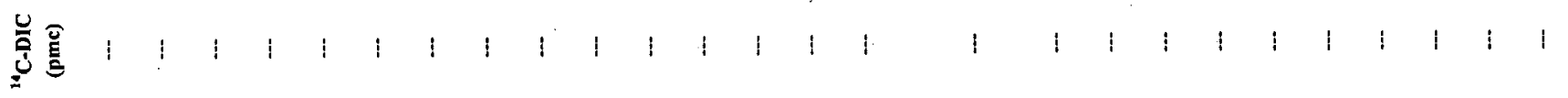

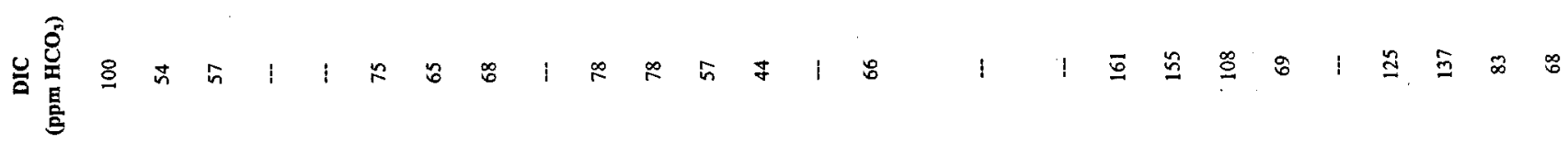

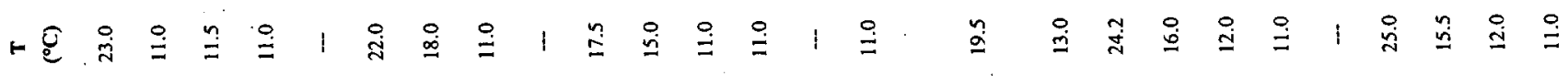

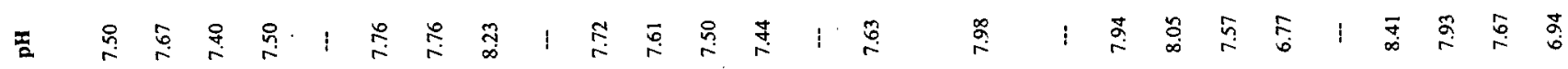

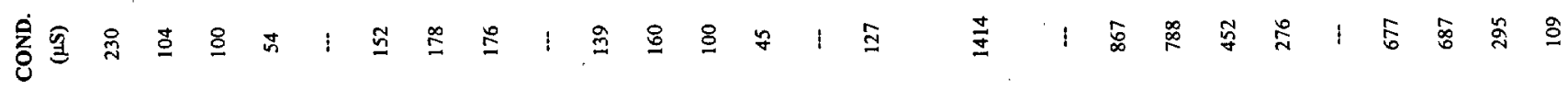
造高1

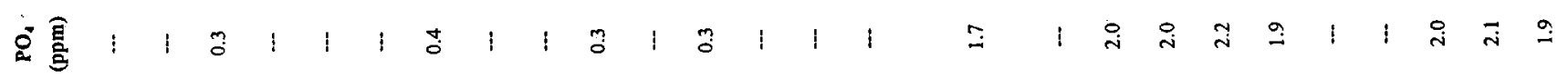

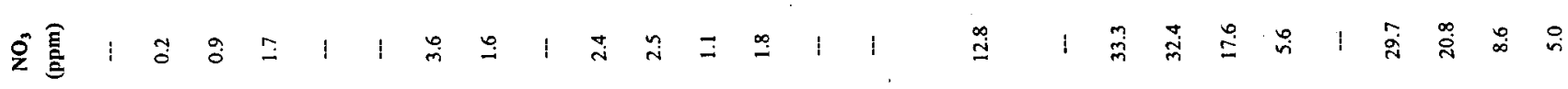

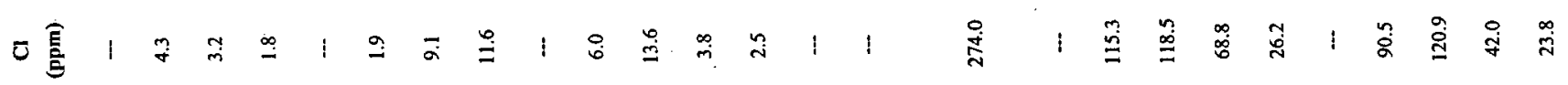

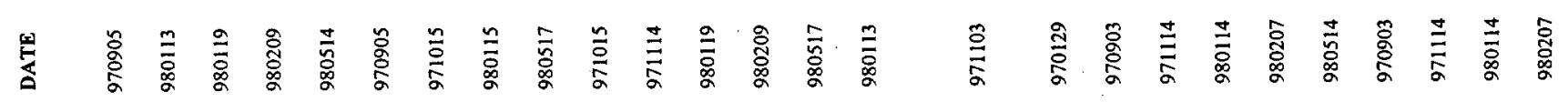

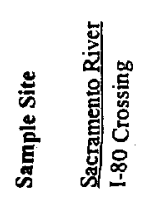

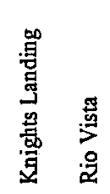

离密

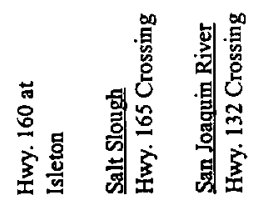




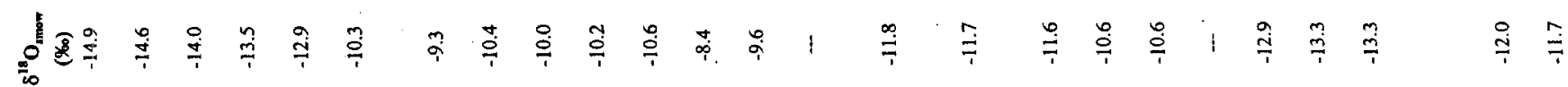

置

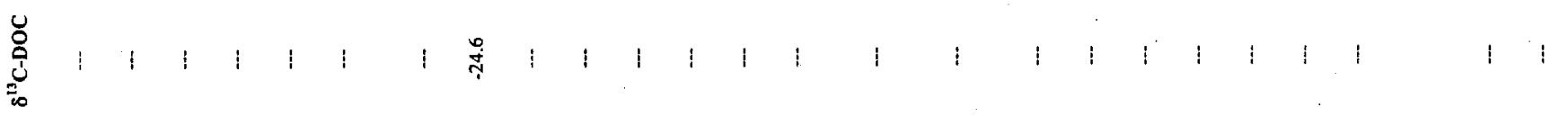

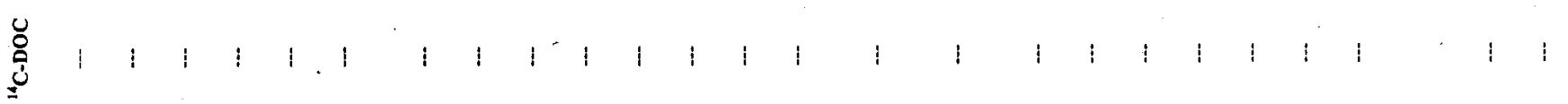

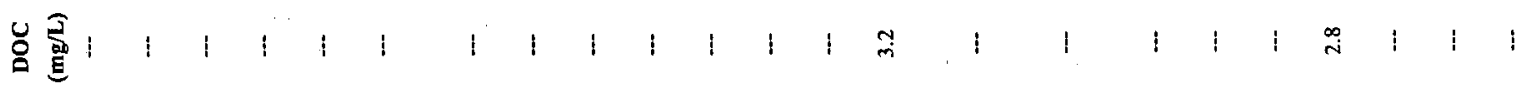

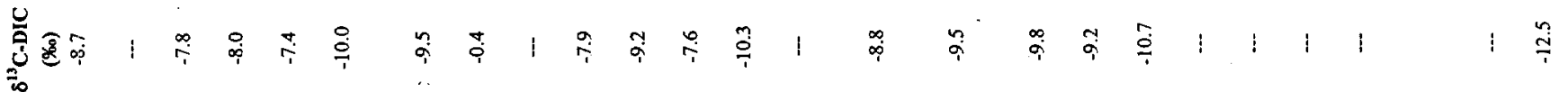

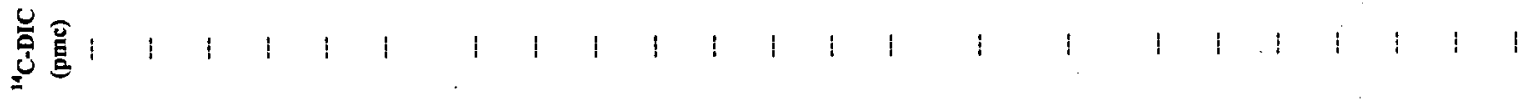

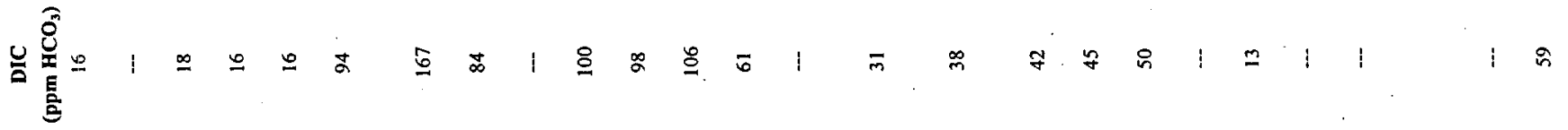

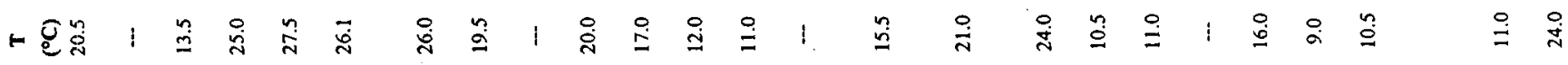

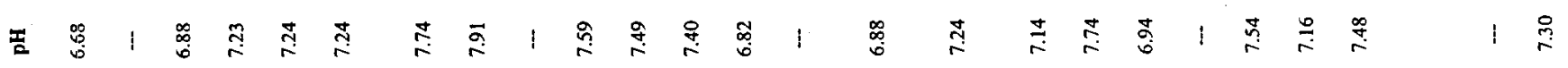

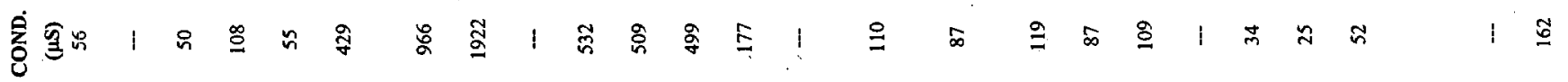

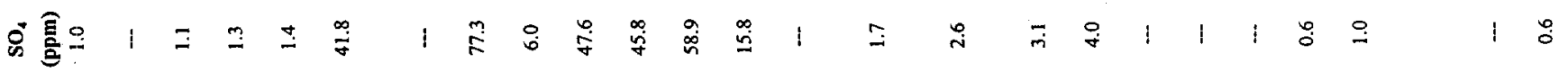

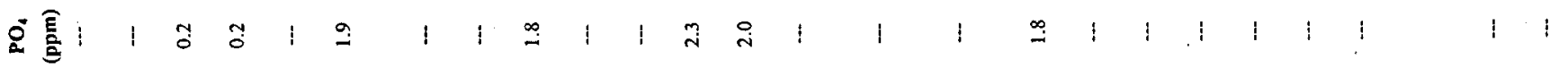

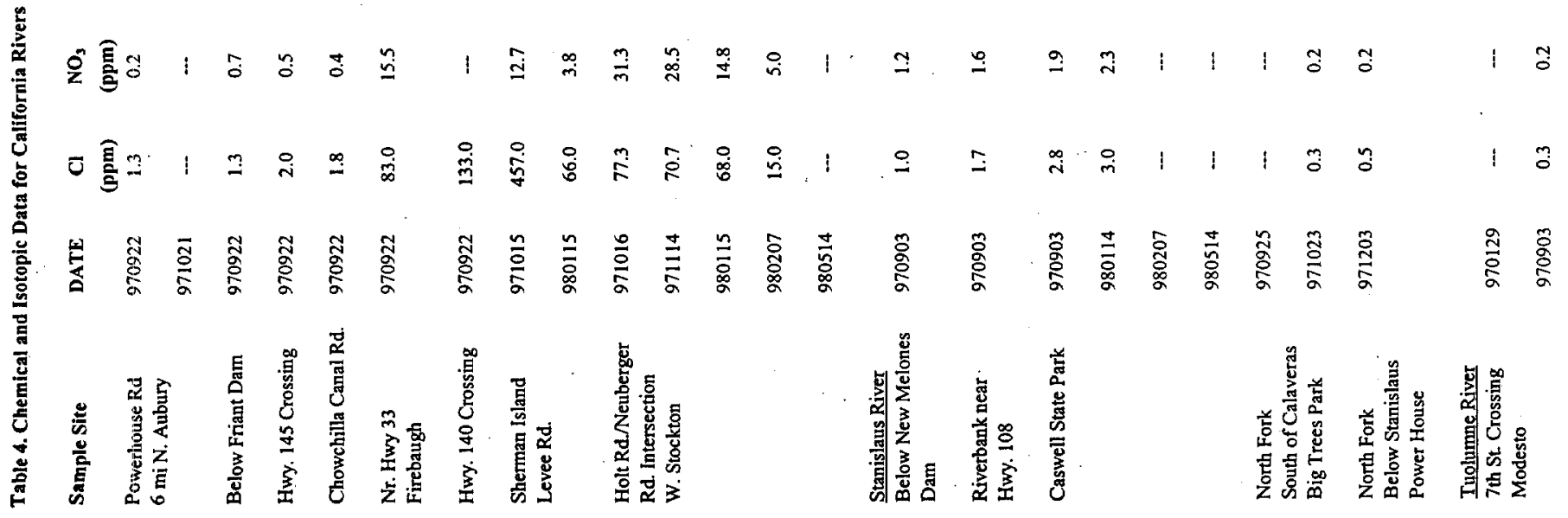


点

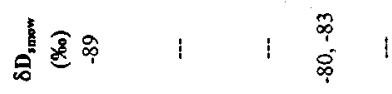

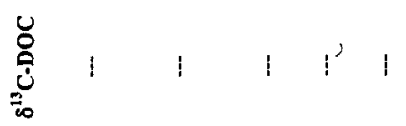

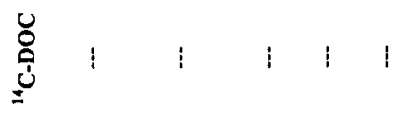

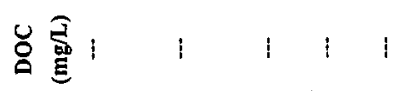

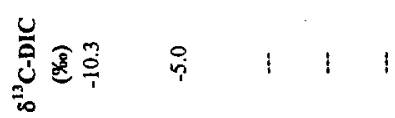

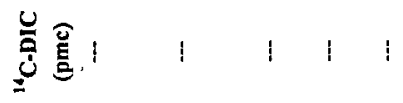

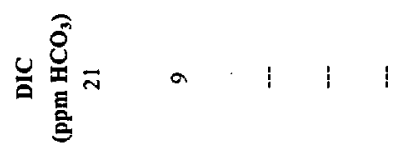

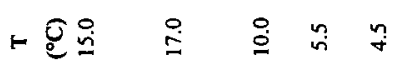

픙

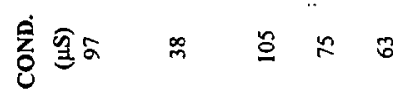

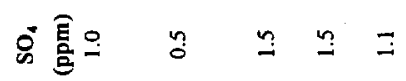

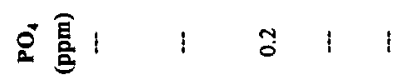

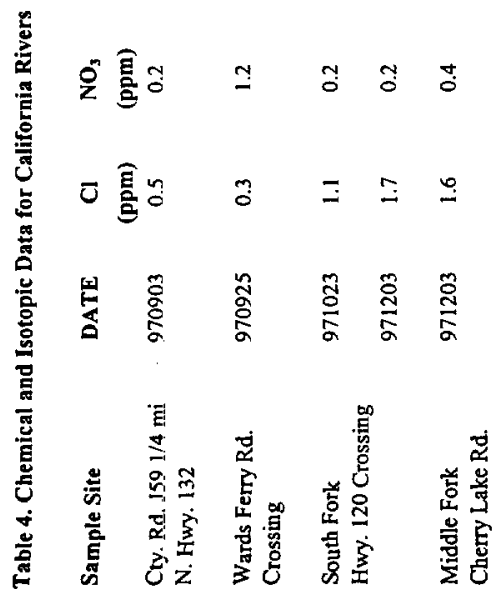


宸

을

8ํำ

ลิ ํㅡㄴ

尊变

哀

赔递: 11

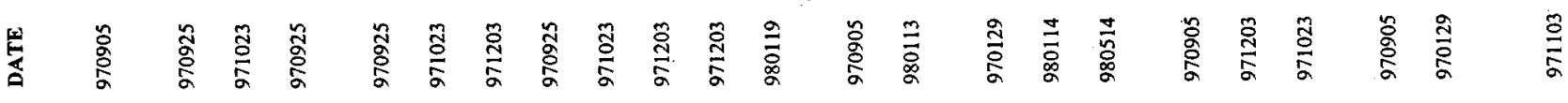

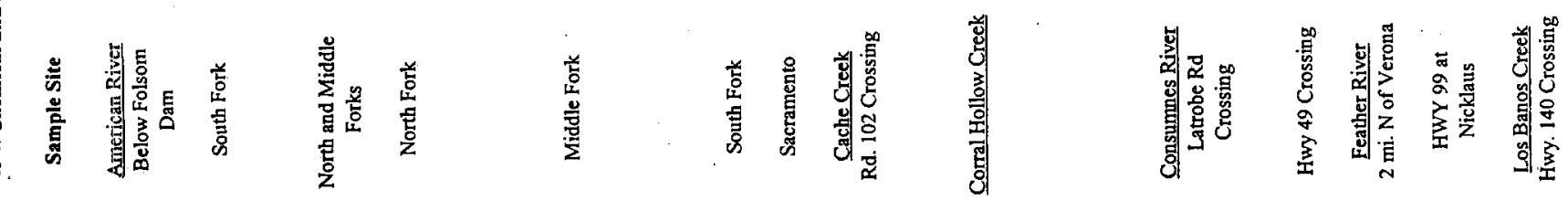


跑突 产音 1

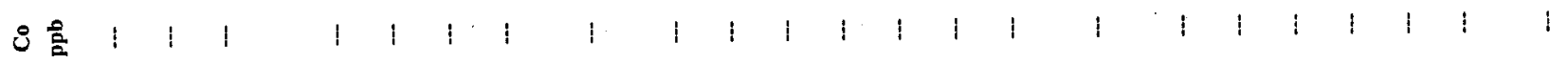
윤 를 i 总造

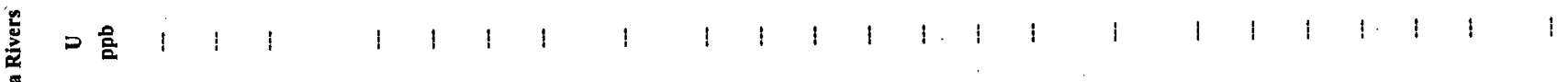

륭

売

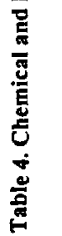
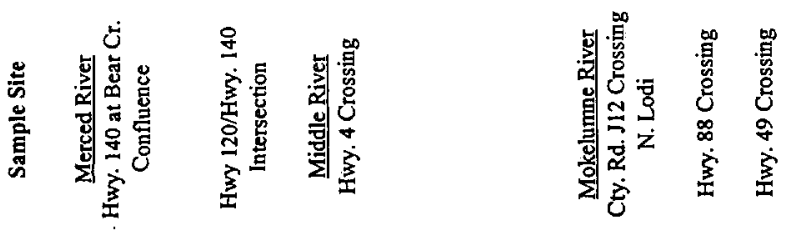

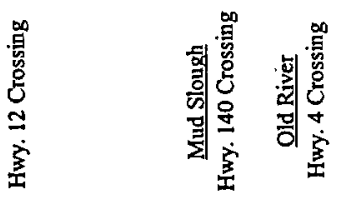




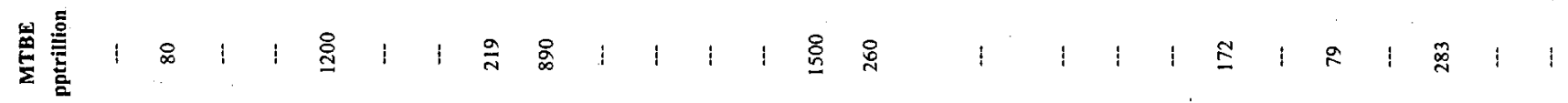
里

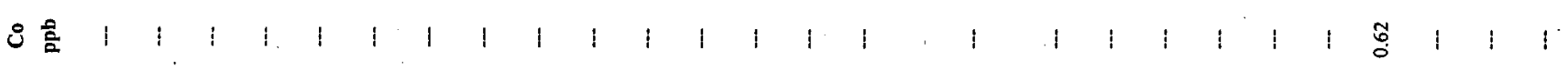

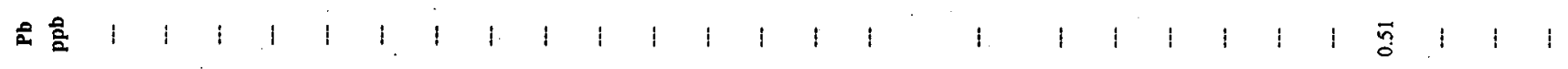

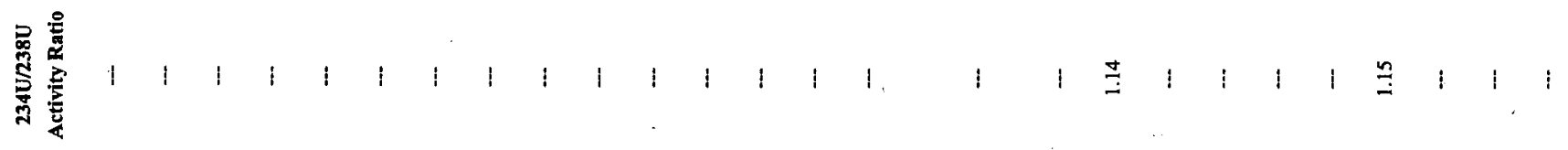

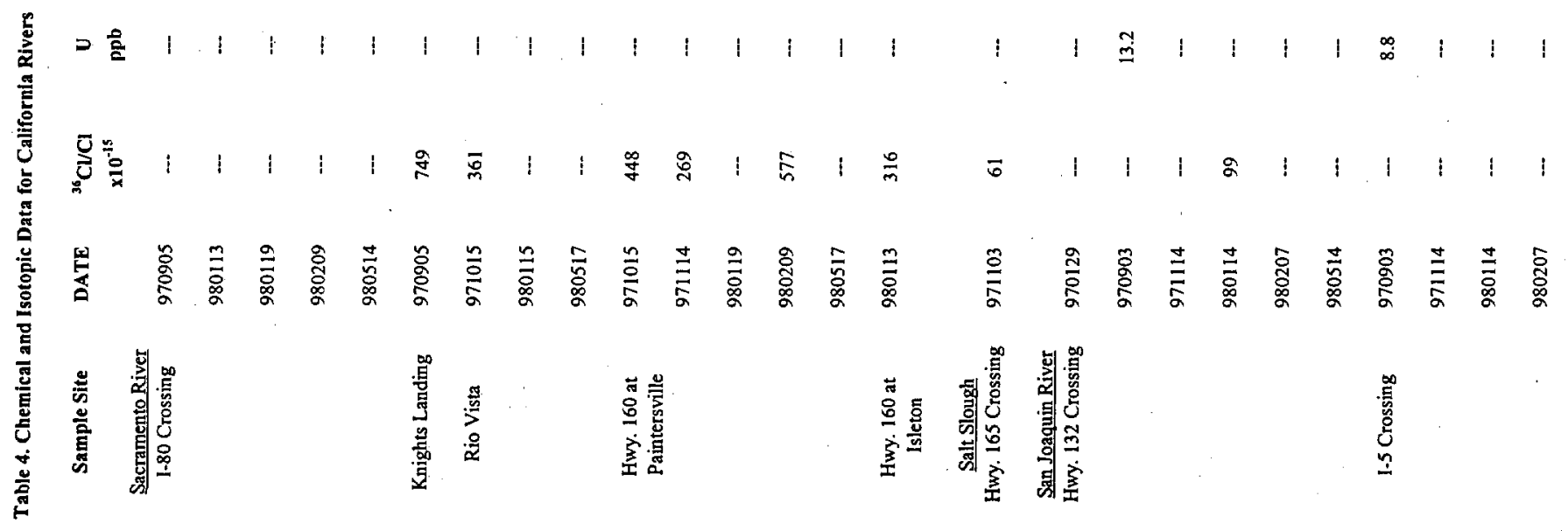


宸

$$
71: \cong 1 \text { 요 }
$$

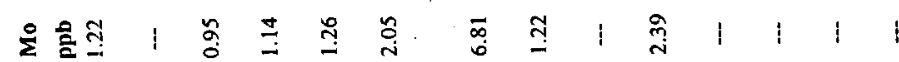

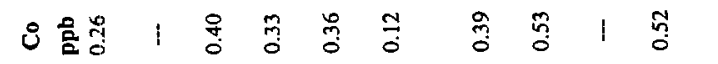

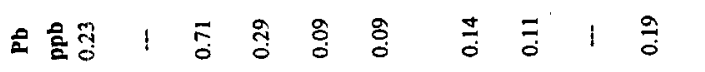

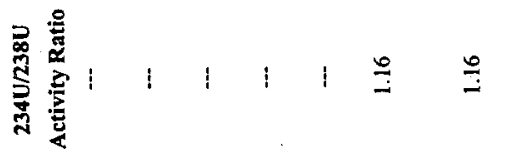

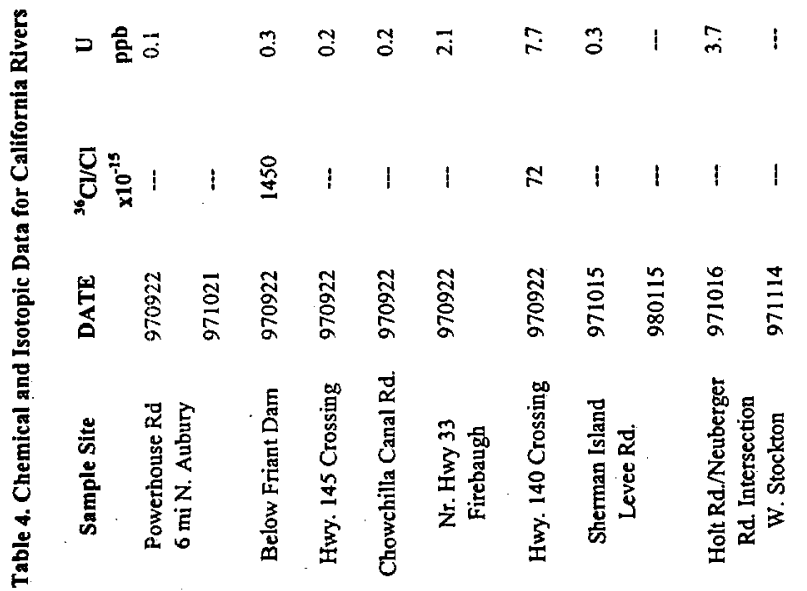

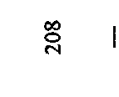


里

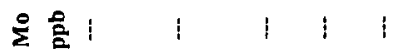

8 흘 1 1 1

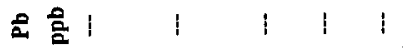

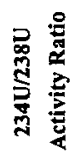

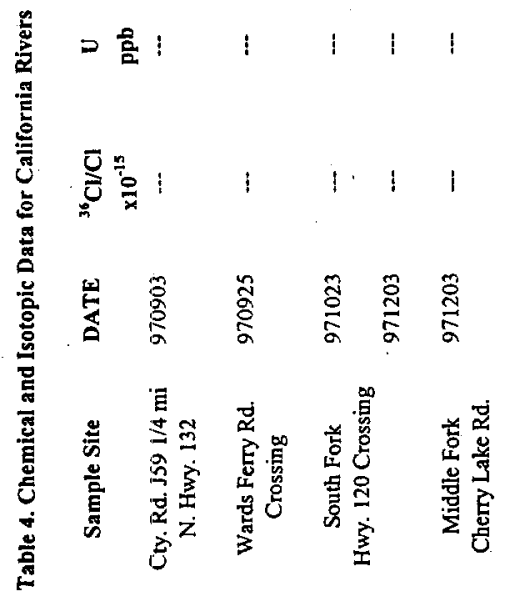




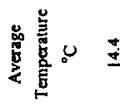

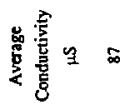

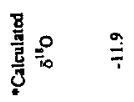

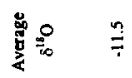

ไุ.$$
\text { (a) }
$$$$
\text { 咅呈 }
$$$$
\text { The }
$$

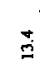$$
\$
$$$$
\vec{g}
$$$$
\approx
$$$$
\dddot{\square}
$$

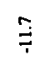$$
\text { พุำ }
$$

$\stackrel{n}{9}$

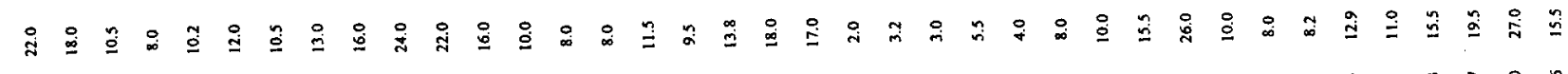

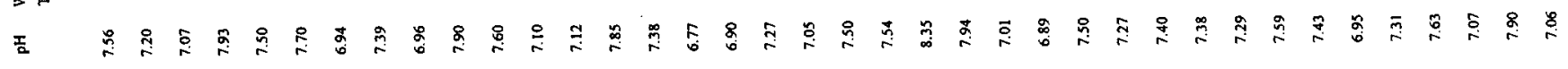
J

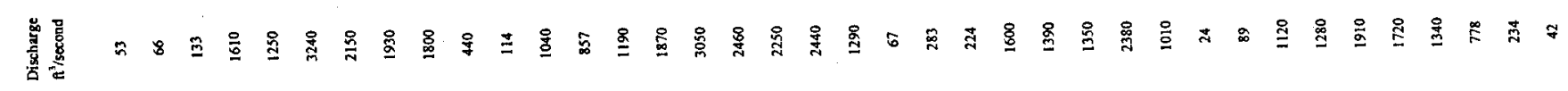

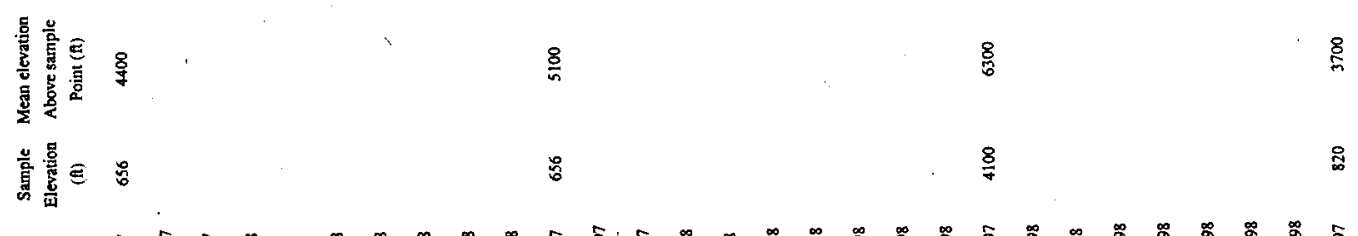

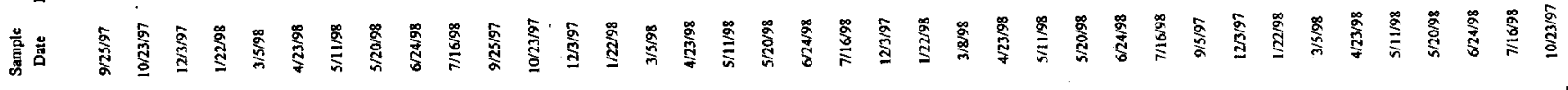

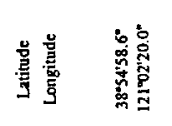

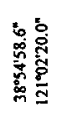

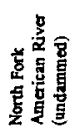

㐫

竞要

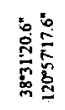

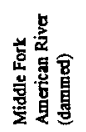

密蜜 
In:

$\sqrt{15}=$

Io:

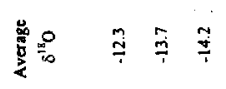

\&

:0

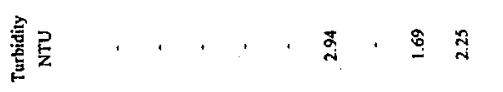

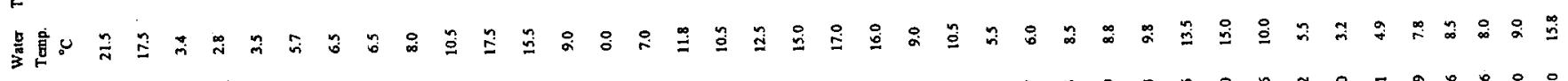

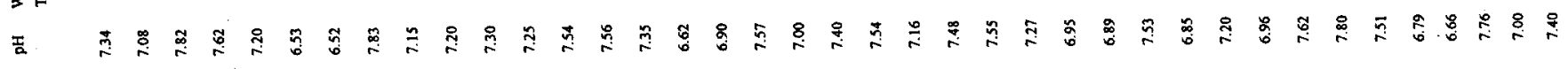

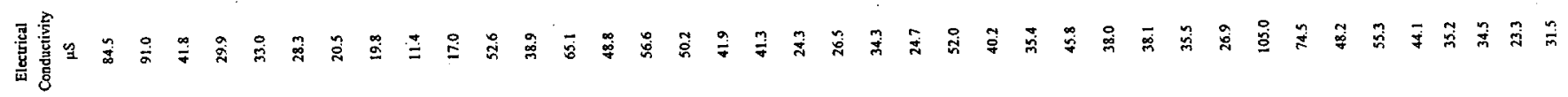

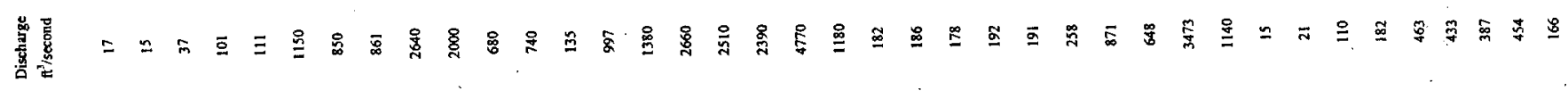

s.

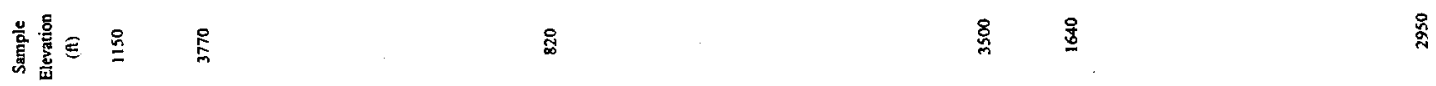

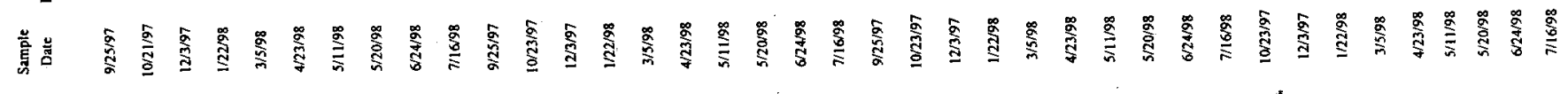

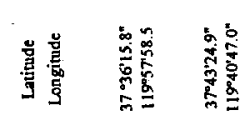

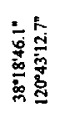

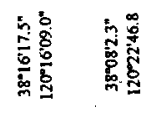

影

㖕

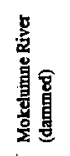

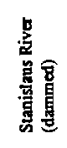

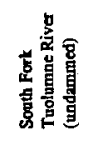




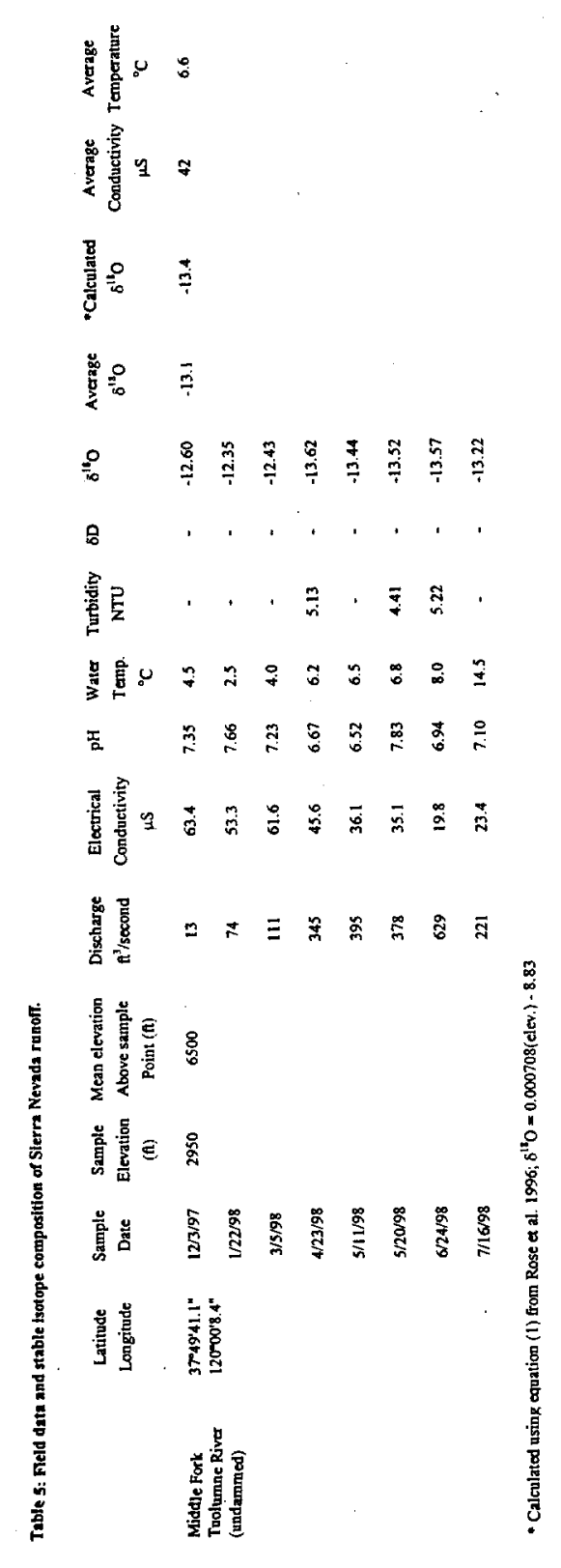

